GROUND-WATER RESOURCES OF WILLIAMS COUNTY, OHIO, 1984-86

By Alban W. Coen, III

U.S. GEOLOGICAL SURVEY

Water-Resources Investigations Report 89-4020

Prepared in cooperation with the

CITY OF BRYAN; VILLAGES OF EDGERTON, EDON, AND MONTPELIER; AND CENTER, JEFFERSON, AND PULASKI TOWNSHIPS, OHIO

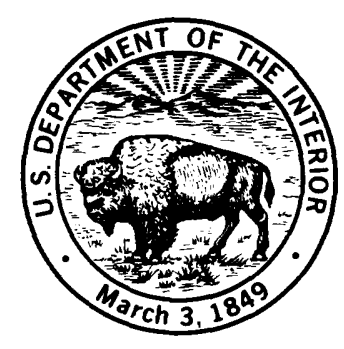

Columbus, Ohio 1989 


\section{DEPARTMENT OF THE INTERIOR}

MANUEL LUJAN, JR., Secretary

\section{U.S. GEOLOGICAL SURVEY}

Dallas L. Peck, Director

For additional information write to:

District Chief

U.S. Geological Survey

$975 \mathrm{~W}$. Third Avenue

Columbus, $\mathrm{OH}$ 43212-3192
Copies of this report can be purchased from:

U.S. Geological Survey Books and Open-File Reports Box 25425, Federal Center Building 810 Denver, CO 80225 


\section{CONTENTS}

Glossary VIII

Abstract 1

Introduction 2

Background 2

Purpose and scope 2

Methods of study 2

Acknowledgments 10

Description of study area 10

Geographic setting 10

Geologic setting 11

Geohydrologic framework 18

Aquifers 19

Unconsolidated sediments 19

Bedrock 20

Ground-water levels, recharge, and discharge $\mathbf{2 2}$

Ground-water/surface-water relations $\mathbf{2 8}$

Ground-water availability $\mathbf{3 0}$

Well yields $\mathbf{3 0}$

Unconsolidated sediments $\mathbf{3 0}$

Bedrock 31

Effects of pumping $\quad \mathbf{3 1}$

Ground-water flow $\mathbf{3 2}$

Directions of flow $\mathbf{3 3}$

Simulation of flow $\mathbf{3 4}$

Description of the conceptual model $\mathbf{3 4}$

Estimated water budget for the Williams County area $\mathbf{3 6}$

Description and construction of the mathematical model $\mathbf{3 8}$

Calibration and sensitivity analysis $\mathbf{4 2}$

Prediction of effects of hypothetical pumping scenarios $\mathbf{4 4}$

Ground-water quality 46

Areal differences $\mathbf{4 9}$

Seasonal variations $\mathbf{5 2}$

Summary $\mathbf{5 2}$

Selected references $\mathbf{5 4}$ 


\section{ILLUSTRATIONS}

Figure 1. Map showing Williams County, Ohio 3

2. Sample driller's $\log$ for well in Williams County 5

3. Map showing well network and stream-sampling sites 6

4. Map showing water-quality sampling sites 7

5. Stratigraphic column for Williams County, Ohio 12

6. Map showing distribution of bedrock and unconsolidated sediments, Williams County, Ohio 14

7. Map showing probable altitude of top of bedrock surface in Williams County, Ohio 16

8. Map showing thickness of unconsolidated sediments in Williams County Ohio 17

9. Generalized geologic sections through Williams County, Ohio (In pocket)

10. Map showing potentiometric surface of Williams County, Ohio 23

11. Hydrographs of water levels in selected wells and of precipitation in Williams County, Ohio, November 1984 through

November $1986 \quad 25$

12. Map showing location of wells for which hydrographs are presented in figure $11 \quad 27$

13. Map showing stream gain/loss study sites, stream discharge, and stream drainage areas 29

14. Generalized hydrogeologic section showing ground-water flow pattern in Williams County, Ohio 35

15. Sketch showing conceptual model of the ground-water system in Williams County, Ohio 37

16. Grid for computer simulation discretization (In pocket)

17. Map showing simulated potentiometric surface compared with measured potentiometric surface (In pocket)

18. Map showing effects of pumping on simulated potentiometric surface (In pocket)

19. Map showing simulated drawdowns for hypothetical wells in Williams County, Ohio 45

20. Piper diagram showing general water-quality relations of ground water and surface water in Williams County, Ohio 47

21. Map with Stiff diagrams showing areal differences in water-quality in Williams County, Ohio $\mathbf{5 0}$

22. Piper diagram showing seasonal variations in ground-water quality $\mathbf{5 1}$ 


\section{TABLES}

Table 1. Well information and water levels from selected wells in Williams County, Ohio 58

2. Organic chemicals and toxic metals selected for analysis $\mathbf{8}$

3. Transmissivity and storage-coefficient values from pump tests in Williams County, Ohio 21

4. Estimated water use in Williams County, Ohio $\mathbf{3 2}$

5. Estimated and simulated water budgets for the ground-water system in Williams County, Ohio 38

6. Quality of water from selected streams and wells in Williams County, Ohio, 198571

7. Water-quality statistics for ground water in Williams County, Ohio 48

8. Characteristics or constituents that affect water quality 91

9. Some methods of dealing with problem water quality $\mathbf{9 4}$ 


\section{CONVERSION FACTORS}

For use of readers who prefer to use metric (International System) units, rather than the inch-pound terms used in this report, the following conversion factors may be used:

\begin{tabular}{|c|c|c|}
\hline Multiply inch-pound unit & By & To obtain metric unit \\
\hline inch (in.) & 25.4 & millimeter $(\mathrm{mm})$ \\
\hline foot $(f t)$ & 0.3048 & meter $(\mathrm{m})$ \\
\hline mile (mi) & 1.609 & kilometer $(\mathrm{km})$ \\
\hline square foot $\left(\mathrm{ft}^{2}\right)$ & 0.09290 & square meter $\left(\mathrm{m}^{2}\right)$ \\
\hline square mile $\left(\mathrm{mi}^{2}\right)$ & 2.590 & square kilometer $\left(\mathrm{km}^{2}\right)$ \\
\hline gallon (gal) & 3.785 & liter $(\mathrm{L})$ \\
\hline $\begin{array}{l}\text { million gallons } \\
(\mathrm{Mgal})\end{array}$ & 3,785 & $\begin{array}{l}\text { cubic meter } \\
\qquad\left(\mathrm{m}^{2}\right)\end{array}$ \\
\hline $\begin{array}{l}\text { foot per second } \\
(\mathrm{ft} / \mathrm{s})\end{array}$ & 0.3048 & $\begin{array}{l}\text { meter per second } \\
\qquad(\mathrm{m} / \mathrm{s})\end{array}$ \\
\hline foot per day (ft/d) & 0.3048 & meter per day $(\mathrm{m} / \mathrm{d})$ \\
\hline $\begin{array}{l}\text { foot per mile } \\
(\mathrm{ft} / \mathrm{mi})\end{array}$ & 0.1894 & $\begin{array}{l}\text { meter per kilometer } \\
\quad(\mathrm{m} / \mathrm{km})\end{array}$ \\
\hline $\begin{array}{l}\text { cubic foot per day } \\
\left(\mathrm{ft}^{3} / \mathrm{d}\right)\end{array}$ & 0.02832 & $\begin{array}{l}\text { cubic meter per day } \\
\left(\mathrm{m}^{3} / \mathrm{d}\right)\end{array}$ \\
\hline $\begin{array}{l}\text { gallon per minute } \\
(\mathrm{gal} / \mathrm{min})\end{array}$ & 0.06308 & $\begin{array}{l}\text { liter per second } \\
(\mathrm{L} / \mathrm{s})\end{array}$ \\
\hline $\begin{array}{l}\text { gallon per day } \\
(\mathrm{gal} / \mathrm{d})\end{array}$ & 0.003785 & $\begin{array}{l}\text { cubic meter per day } \\
\left(\mathrm{m}^{3} / \mathrm{d}\right)\end{array}$ \\
\hline $\begin{array}{l}\text { gallon per day } \\
\text { per foot }(\mathrm{gal} / \mathrm{d} / \mathrm{ft})\end{array}$ & 0.01242 & $\begin{array}{l}\text { cubic meter per day } \\
\text { per meter }\left(\mathrm{m}^{3} / \mathrm{d} / \mathrm{m}\right)\end{array}$ \\
\hline $\begin{array}{l}\text { gallon per day per foot } \\
\text { squared (gal/d)/ft }\end{array}$ & 0.0407 & $\begin{array}{l}\text { cubic meter per day per } \\
\text { meter squared }\left(\mathrm{m}^{3} / \mathrm{d} / \mathrm{m}^{2}\right)\end{array}$ \\
\hline $\begin{array}{l}\text { million gallons per } \\
\text { day (Mgal/d) }\end{array}$ & 0.04381 & $\begin{array}{l}\text { cubic meter per second } \\
\left(\mathrm{m}^{3} / \mathrm{s}\right)\end{array}$ \\
\hline
\end{tabular}

Temperature in degrees Fahrenheit $\left({ }^{\circ} \mathrm{F}\right)$ can be converted to degrees Celsius $\left({ }^{\circ} \mathrm{C}\right)$ as follows:

$$
{ }^{\circ} \mathrm{F}=1.8\left({ }^{\circ} \mathrm{C}\right)+32
$$

Sea level: In this report "sea level" refers to the National Geodetic Vertical Datum of 1929 (NGVD of 1929) - a geodetic datum derived from a general adjustment of the firstorder level nets of both the United States and Canada, formerly called "Sea Level Datum of 1929." 


\section{GLOSSARY}

The following are definitions of selected technical terms as they are used in this report; they are not necessarily the only valid definitions for these terms. Terms defined in the glossary are in bold print where first used in the main body of this report.

Anion.-An atom, group of atoms, or molecule that has a net negative charge.

Aquifer.-A layer of sediments or rocks that is porous and permeable enough to conduct a useful amount of water.

Cation.-An atom, group of atoms, or molecule that has a net positive charge.

Conceptual model.-A description or working hypothesis about cause-and-effect relations in processes or systems that cannot be observed directly. In this report, conceptual refers to the general concept of the ground-water system in Williams County.

Cone of depression.-A depression of water levels centered on a pumping well. The size and shape of the cone of depression is determined by the transmissivity and storage coefficient of the aquifer and by the rate of pumping of the well. Transmissive aquifers have shallow cones of depression with large diameters. Aquifers with low transmissivities have small but deep cones.

Confined aquifer.-A saturated aquifer confined by a layer of earth material that hampers movement of water in and out of the aquifer.

Consolidated rock.-Mineral particles of different sizes and shapes that have been welded by heat and pressure or by chemical reactions into a solid mass. Such rocks are commonly referred to in ground-water reports as "bedrock" (Heath, 1983). Examples of consolidated rock include limestone, sandstone, and shale.

Drawdown.-A water-level drop in a well caused by pumping.

End moraine.-A ridgelike accumulation of unconsolidated sediments that forms along the margin of a glacier.

Ground moraine.- Unconsolidated sediments that accumulated beneath a glacier; has little relief and no ridgelike structure.

Hydraulic conductivity.-The volume of water that will flow through a cross-sectional area under a specific gradient during a specific length of time. Hydraulic conductivity is reported as feet per day $(\mathrm{ft} / \mathrm{d})$ or meters per day $(\mathrm{m} / \mathrm{d})$. Clean sands and gravels 
can have hydraulic conductivities of $10 \mathrm{ft} / \mathrm{d}$ to $1,000 \mathrm{ft} / \mathrm{d}$, which are considered high to very high. Hydraulic conductivities of sandstones range from about 0.01 to 10 $\mathrm{ft} / \mathrm{d}$. Shale, silt, clay, till, and mixtures of sand, silt, and clay can have hydraulic conductivities of 0.0001 to $1 \mathrm{ft} / \mathrm{d}$, which are considered low to very low (Todd, 1980).

Hydraulic head.-The height above a given datum to which a column of ground water will rise.

Isotropic.-Identical in all directions.

Mathematical model.-A mathematical representation or simulation of a conceptual model by means of equations relating inputs, outputs, and internal characteristics of the system or process being modeled.

Parameter.-An element in a mathematical expression or equation that can be changed to bring about different cases of the system being represented. In this report, examples of parameters include values for recharge, hydraulic conductivity, and so forth, in the mathematical ground-water model.

Permeability.-The ability of a rock or sediment to transmit a fluid. Permeability depends on the amount of pore space (porosity) of a rock and how well the pores are connected. The larger the size and number of the connecting passages, the higher the permeability. A rock can have high porosity and low permeability if most of its pores are not connected. Sands and gravels usually have high permeabilities, whereas shales, clay, and till usually have low permeabilities. Permeability can vary, depending on the direction of fluid movement through rock or sediment. Most sediments are originally deposited in horizontal layers. Permeability is often much higher along these layers than it is between layers.

Porosity.-The amount of pore space or voids in rock. Some or all of this volume can be filled by water. Sand, gravel, and sandstone can have porosities as high as 30 to 40 percent-that is, 30 to 40 percent of the volume of the rock or sediment is empty space between grains and can be filled with water. Shale has a porosity of about 6 percent. Mixtures of sand, gravel, silt, and clay can have low porosities. Tills can have a range of porosities from low to about 30 percent (Freeze and Cherry, 1979).

Potentiometric surface.-A surface defined by the levels to which water will rise in tightly cased wells in confined or unconfined aquifers.

Semiconfined aquifer.-An aquifer capped by a leaky confining layer; that is, some water can seep up or down through the confining layer. 
Specific capacity.-The rate of discharge of a water well per unit of drawdown.

Steady state.-In equilibrium. In terms of ground-water systems, the amount of water leaving the system equals the amount of water entering the system.

Storage coefficient.-The amount or volume of water an aquifer takes into or releases from storage when the head changes by a specific amount. The head in an unconfined aquifer is equal to the water level. In a confined aquifer, however, the head is the level to which water will rise in a well open to the aquifer. The storage coefficient is large for unconfined aquifers-a great deal of water will go into or out of storage when the head changes. The coefficient is much smaller (10 to 1,000 times smaller) for confined aquifers.

Till.--Unsorted and unstratified glacial deposit consisting of a heterogeneous mixture of clay, sand, silt, gravel, and boulders varying widely in size, shape, and composition.

Transmissivity.-The hydraulic conductivity of an aquifer multiplied by the saturated thickness (in feet or in meters) of the aquifer.

Unconfined.-Not confined by an impermeable bed but open to the atmosphere. The water level near the ground surface in an unconfined aquifer is sometimes called the "water table."

Unconsolidated sediments.-Rock material consisting of uncemented particles, such as gravel, sand, silt, or clay. 


\title{
GROUND-WATER RESOURCES OF WILLIAMS COUNTY, OHIO, 1984-86
}

\author{
By Alban W. Coen, III
}

\begin{abstract}
This report presents the results of a county-wide ground-water appraisal of Williams County, a mostly agricultural county of more than 36,000 people that is undergoing gradual commercial and industrial development. Most of the County's ground water is in the 80- to 320-foot-thick cap of unconsolidated glacial sediments. The underlying Mississippian and older bedrock units are mostly shale and contain little potable water at economically recoverable depths. The glacial deposits are mostly Wisconsin till containing discontinuous lenses of sand and gravel. Two end moraines that cross the County form low northeast-southwest-trending ridges. Ground moraine covers the rest of the County, except for fine sand and silt lacustrine sediments in the southeastern corner. The waterbearing sand and gravel bodies appear to be thickest and most widespread in the end moraines and thinnest and more localized in the lacustrine sediments. A generally productive (up to 1,000 gallons per minute) zone of sand and gravel and broken, weathered rock is present in places at the contact of the unconsolidated sediments and the shale.
\end{abstract}

A study of well logs and aquifer tests shows that well yields of 500 gallons per minute are possible over all but the southeastern corner of the County. Transmissivities range from 2,800 to more than 64,300 feet squared per day. Storage coefficients that range from 0.0001 to 0.00038 indicate confined to semiconfined conditions.

A gently southeast-sloping water-level surface was identified by measuring water levels in an 87-well network. A potentiometric-surface map constructed from these water-level measurements shows a fairly consistent gradient of 10 to 30 feet per mile across the County, which indicates that the unconsolidated sediments, on a large scale, act as one aquifer. Ground water flows toward the southeast. The recharge area for the ground-water system includes Williams County and the area just to the northwest of Williams County, whereas the discharge areas are mainly the streams within and to the southeast of the County.

Water quality in the unconsolidated sediments was evaluated through the analysis of samples from 48 wells. The predominantly calcium magnesium bicarbonate type water generally is suitable for most uses, but is hard and high in iron. The median $\mathrm{pH}$ is 7.6, the median specific conductance is 660 microsiemens per centimeter, the median iron 
concentration is 1.4 milligrams per liter, and the median hardness $\left(\right.$ as $\mathrm{CaCO}_{3}$ ) is 290 milligrams per liter. Water in the southeastern corner of the County contains more sodium than elsewhere in the County. Seasonal variations in the ground-water quality are small. Analysis of four samples showed the water quality of area streams at base flow to be very similar, although slightly more dilute and less hard than the ground water.

\section{INTRODUCTION}

\section{Background}

Williams County (fig. 1) and the northwestern corner of Ohio have always had abundant ground water of good quality. The area continues to develop, and small industries have supplemented the agricultural economy. Information on the quantity and quality of the ground water is needed to ensure supplies for municipal and rural users and for industry. Previous studies have concentrated on specific areas of the County or on certain aspects of the hydrology. No study easily accessible to the layman has assimilated the previous work and presented a current assessment of the quality and quantity of the ground water in Williams County.

\section{Purpose and Scope}

The purpose of this report is to describe the availability, flow, and quality of ground water in the shallow aquifers ${ }^{1}$ in the unconsolidated sediments of Williams County, Ohio. Water levels in 87 wells were measured from November 1984 through November 1986, and potentiometric maps were drawn. Water-quality data were collected from 48 wells and four streams in 1985. A stream gain/loss study was conducted to help determine the relations between surface water and ground water. A conceptual model of the ground-water system was developed. Ground-water flow in the County was computer simulated as an aid to understanding the hydrologic system and to evaluate the aquifer's response to external stresses.

\section{Methods of Study}

Ground-water resources of Williams County were studied through examination of well-drillers' logs, by measurement of water levels in a network of wells, by preparation of potentiometric-surface maps, and by sampling selected wells and streams for waterquality analysis.

\footnotetext{
${ }^{1}$ Terms defined in the glossary are in bold print where first used in the main body of this report.
} 


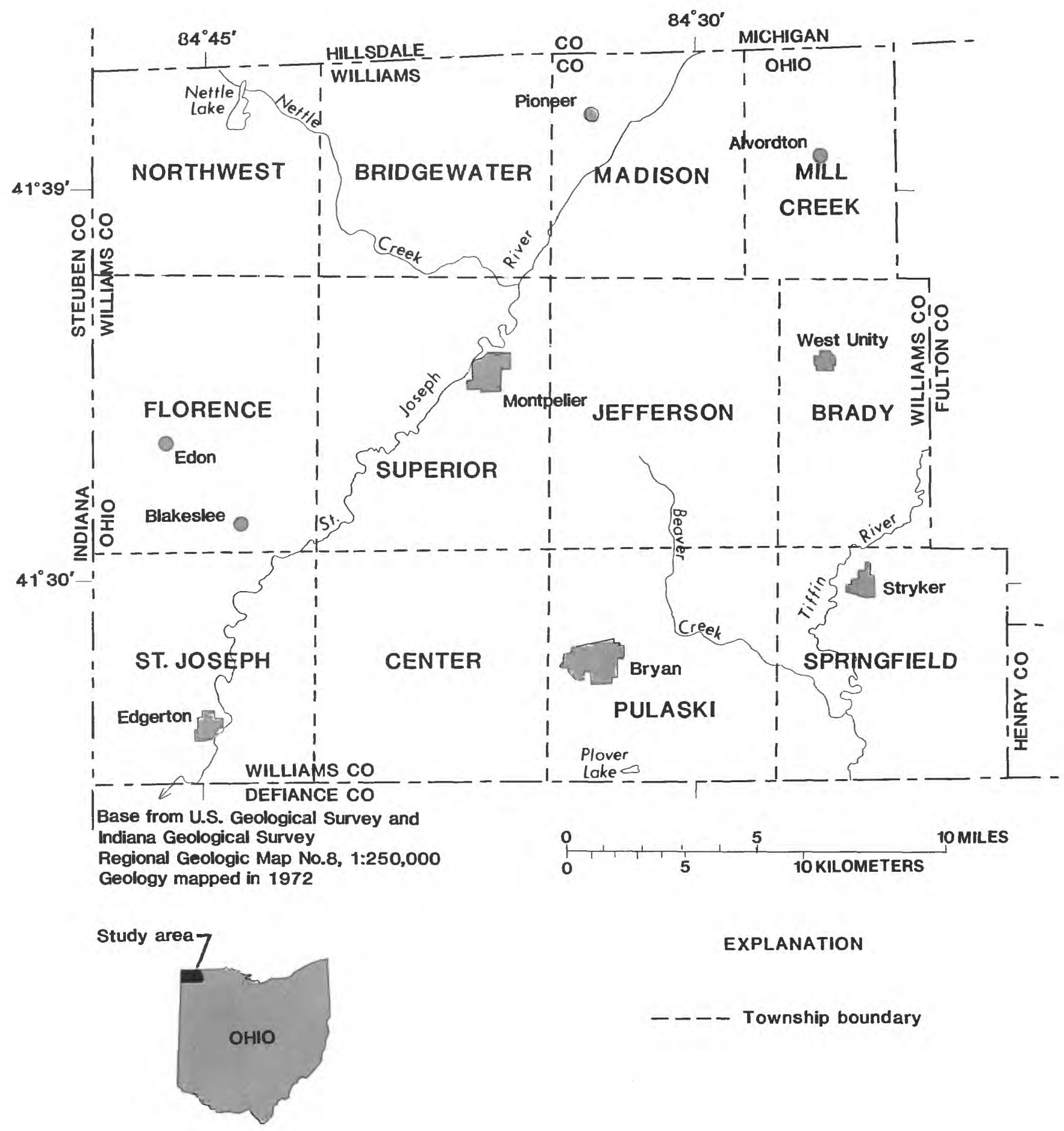

Figure 1.--Williams County, Ohio. 
Several thousand well-drillers' logs for Williams County are on file with the Ohio Department of Natural Resources, Division of Water, in Columbus, Ohio. More than 200 logs representing various geologic deposits in all townships of the County were selected for detailed study. The logs (a sample is shown in fig. 2) were of municipal, commercial, and private domestic wells. Almost all of the wells were drilled after 1974. Since then, new wells have been required to have the well casing extend above ground and have a removable cap, making it possible to easily measure the water level in the well. The logs were used to prepare geologic sections, help determine well yields, and select wells for the well network.

Eighty-seven wells were located in the field, and the altitudes of the wells were determined from U.S. Geological Survey 1:24,000-scale topographic maps. Locations of the wells are shown in figure 3 . All the wells were completed in the unconsolidated sediments. Some wells were drilled into the underlying shale, but produce water primarily from the sand and gravel or from the broken rock and gravel at the contact between the unconsolidated sediments and the shale. Data were collected for 2 years, from November 1984 through November 1986. Four wells were instrumented to continuously record the water level. Levels in 10 wells were measured monthly. The remaining wells were measured quarterly or semiannually. The depth to water below the land surface (water level) was measured through the well casing by means of a steel tape. Well information and the data collected were entered into the U.S. Geological Survey's Ground Water Site Inventory (GWSI) computer data base. Selected well data are presented in table 1 (at back of report).

The measured water levels were converted to altitude above sea level and were plotted to produce potentiometric-surface maps, which show the altitude of the groundwater surface in the unconsolidated deposits. The altitude of the water level in a well is equal to the hydraulic head at that point in the aquifer. The altitude, or head, values are then contoured - that is, lines are drawn on the map connecting points having the same altitude. A sampling program was designed to appraise the general water quality of the water in the unconsolidated sediments in Williams County. A network of 48 wells (fig. 4) was selected for water-quality analysis. The wells were located in all townships of the County. Municipal, commercial, and domestic water supplies were represented. Shallow and deep wells and a spring-fed cistern were included. Four rivers and streams also were sampled for comparison.

Water from the 48 wells was sampled in April 1985 to determine the concentrations of common dissolved constituents. Water from ten of the wells was resampled in November 1985 in order to determine seasonal variations. Water samples from ten wells, including several municipal supplies, and four streams were analyzed in August 1985 for U.S. Environmental Protection Agency priority pollutants and for volatile organic chemicals and toxic metals. The organic chemicals and toxic metals for which samples were analyzed are listed in table 2. Samples from 16 wells also were analyzed for barium. 


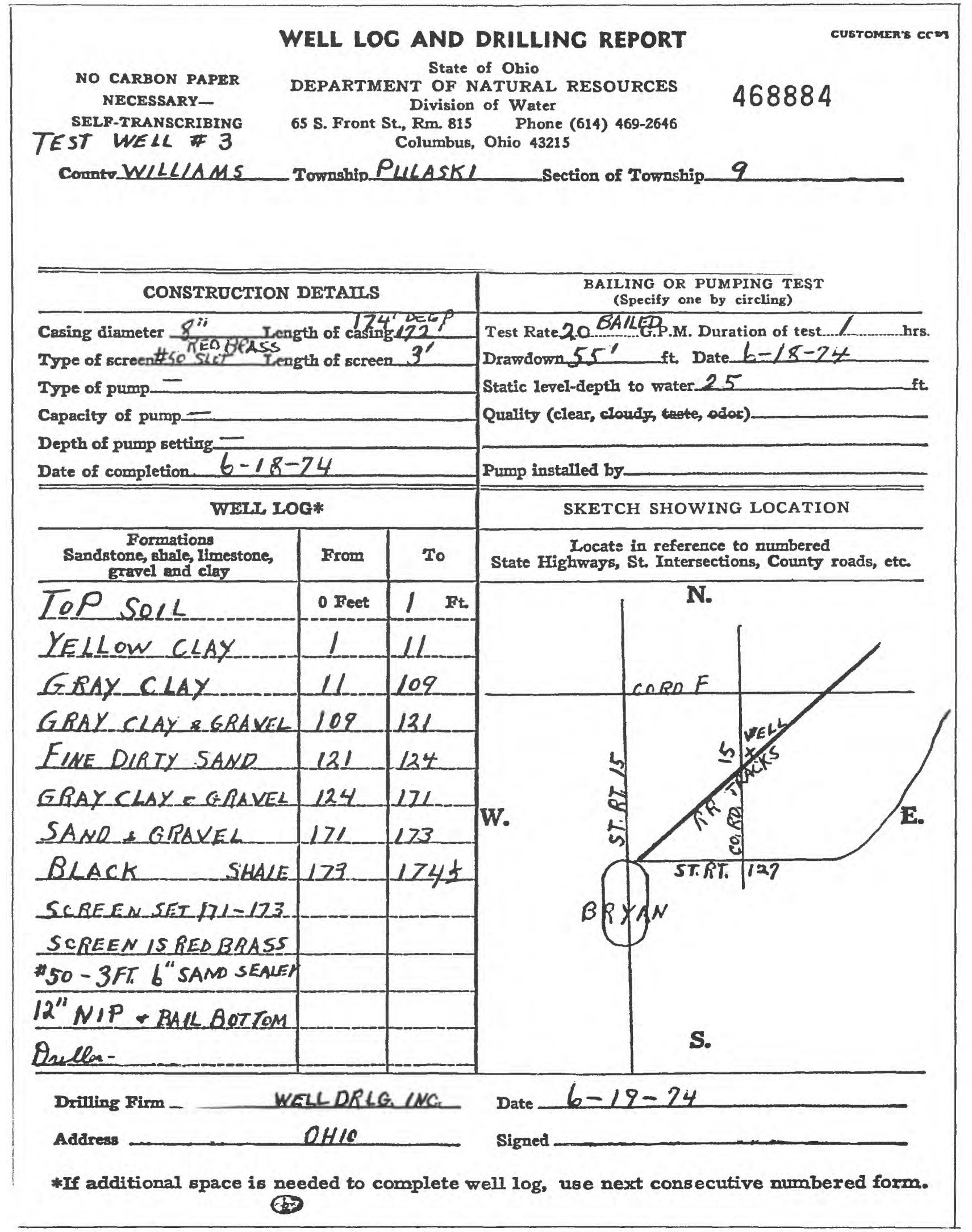

Figure 2.--Sample driller's log for well in Williams County (from Ohio Department of Natural Resources, Division of Water). 


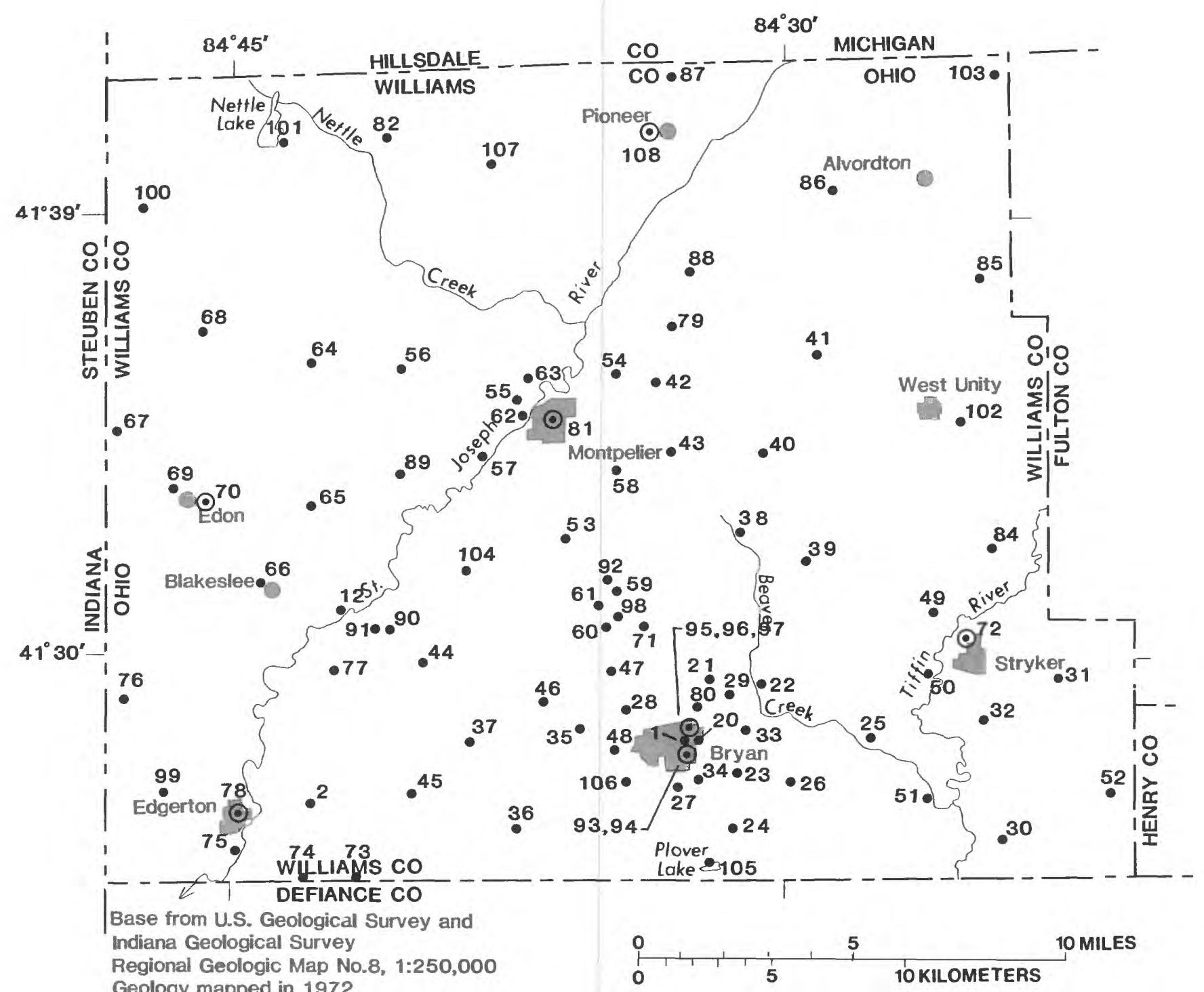

Geology mapped in 1972

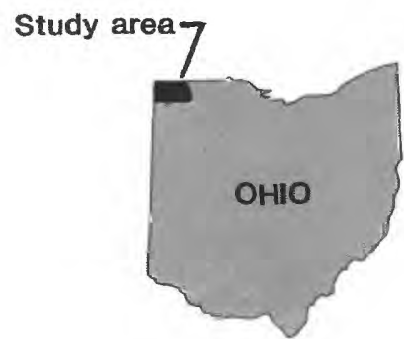

EXPLANATION

12 Domestic, commercial, or observation well

$\odot^{70}$ Municipal supply well

Figure 3.--Observation-well network (the well-code prefix "WM-" and location suffix have been omitted from well numbers). 

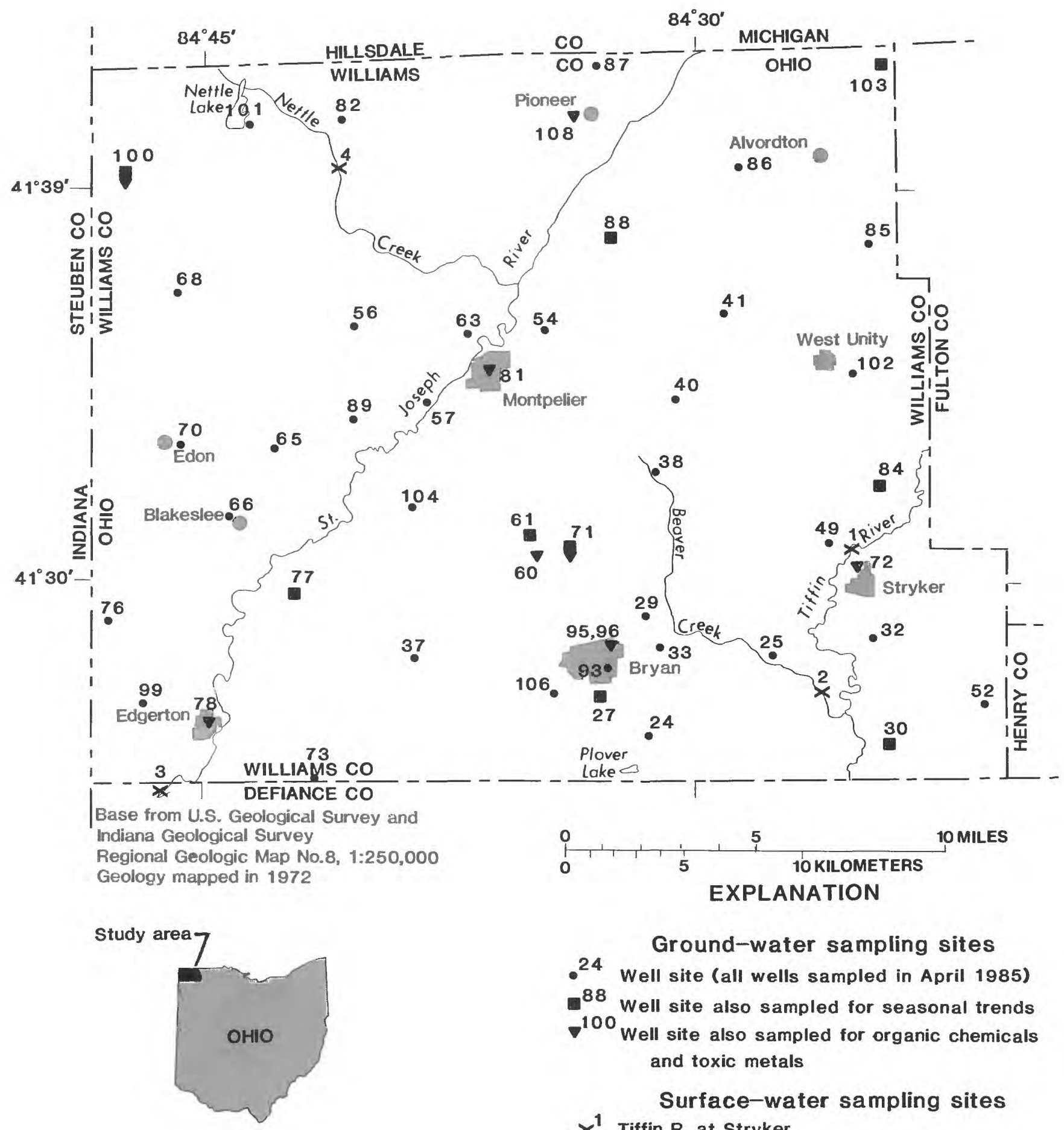
Ground-water sampling sites
-24 Well site (all wells sampled in April 1985)
- 88 Well site also sampled for seasonal trends $\nabla^{100}$ Well site also sampled for organic chemicals and toxic metals

\section{Surface-water sampling sites}

$x^{1}$ Tiffin R. at Stryker

$x^{2}$ Beaver C.. at Co. Rd. C nr Stryker

$\times 3$ St.Joseph R. nr Edgerton

$x^{4}$ Nettle C. at Co. Rd. P-50 nr Nettle Lake

Figure 4.--Water-quality sampling sites (the well-code prefix "WM-" and location suffix have been omitted from well numbers). 
Table 2.--organic chemicals and toxic metals selected for analysis

Organic chemicals

Acenaphthene

Acenaphthylene

Anthracene

Benzene

Benzidine

Benzo (a) anthracene

Benzo (a) pyrene

Benzo (b) fluoranthene

Benzo $(g, h, i)$ perylene

Benzo (k) fluoranthene

Bis(2-chloroethoxy) methane

Bis (2-chloroethyl) ether

Bis(2-chloroisopropyl) ether

Bis(2-ethylhexyl) phthalate

Bromoform

4-Bromophenylphenyl ether

Carbon tetrachloride

Chlorobenzene

Chlorodibromomethane

Chloroethane

Chloroethylene

2-Chloroethylvinyl ether

Chloroform

2-Chloronaphthalene

2-Chlorophenol

4-Chlorophenylphenyl ether

Chrysene

$1,2,5,6$-Dibenzanthracene

1,2-Dichlorobenzene

1,3-Dichlorobenzene

1,4-Dichlorobenzene

Dichlorobromomethane

Dichlorodifluoromethane

1,1-Dichloroethane

1,2-Dichloroethane

1,1-Dichloroethylene

2,4-Dichlorophenol

1,2-Dichloropropane

1,3-Dichloropropane

Diethyl phthalate

2,4-Dimethylphenol

Dimethyl phthalate

Di-n-butyl phthalate

4,6-Dinitroorthocresol

2,4-Dinitrotoluene

2,4-Dinitrotoluene

2,6-Dinitrotoluene 
Table 2.--Organic chemicals and toxic metals selected for analysis--Continued

Organic chemicals--Continued

Di-n-octyl phthalate

Ethylbenzene

Fluoranthene

Fluorene

Hexachlorobenzene

Hexachlorobutadiene

Hexachlorocyclopentadiene

Hexachloroethane

Indeno $(1,2,3$-cd) pyrene

Isophorone

Methylbromide

Methylene chloride

Naphthalene

N-Butyl benzylphthalate

Nitrobenezene

2-Nitrophenol

4-Nitrophenol

N-Nitrosodimethylamine

N-Nit rosodi-n-propylamine

N-Nitrosodiphenylamine

Parachlorometracresol

Pentachlorophenol

Phenanthrene

Pyrene

$2,3,7,8$-Tet rachlorodibenzo-p-dioxin

$1,1,2,2$-Tetrachloroethane

Tetrachloroethylene

Toluene

1,2,4-Trichlorobenzene

1,1,1-Trichloroethane

1,1,2-Trichloroethane

Trichlorofluoromethane

2,4,6-Trichlorophenol

Vinyl chloride

1,1,1-Trichloroethane

1, 1,2-Trichloroethane

Toxic metals

Antimony

Arsenic

Beryllium

Cadmium

Copper

Cyanide
Lead

Mercury

Nickel

Selenium

Silver

zinc 
All sampling was done according to U.S. Geological Survey procedures (Federal Interagency Work Groups, 1977; and U.S. Geological Survey, 1983). The domestic wells were sampled by drawing untreated water either from a field hydrant next to the well or from an outside faucet on the house. Before sampling, water was allowed to flow until measurements of $\mathrm{pH}$, specific conductance, dissolved-oxygen concentration, and temperature, made at 5-minute intervals, stabilized. This took from 20 to $30 \mathrm{~min}$ (minutes), and insured that water sampled most likely represented water in the aquifer. Water from municipal wells was collected from a raw-water tap at the wellhead. Municipal wells were pumping continuously when the samples were collected. Streams were sampled so as to collect a representative sample of all of the flow. The samples were then filtered, preserved, and chilled as needed and shipped on ice to U.S. Geological Survey National Water-Quality Laboratory for analysis. To assure quality and continuity in analytical methods, duplicates of some of the samples were submitted for analysis and the results were compared. Analysis for hydrogen sulfide was performed at the U.S. Geological Survey Ohio District laboratory. Alkalinity, pH, specific conductance, dissolved oxygen, and discharge were determined in the field.

\section{Acknowledgments}

The author thanks the City of Bryan; the Villages of Alvordton, Edgerton, Edon, Montpelier, Pioneer, Stryker, and West Unity; the Williams County Commissioners; the Ohio Department of Natural Resources, Division of Water; and Steve Baggett of the University of Toledo. Appreciation also is expressed to the private well owners of Williams County for making their wells available for measurement of water levels and sampling of ground water.

\section{DESCRIPTION OF STUDY AREA}

\section{Geographic Setting}

Williams County is located in northwestern Ohio and borders Michigan and Indiana (fig. 1). The County encompasses $421 \mathrm{mi}^{2}$ (square miles). In 1980, the population was 36,369 , which was about 8 percent higher than in 1970 . Bryan is the county seat and has more than 8,000 inhabitants. The villages of Alvordton, Blakeslee, Edgerton, Edon, Montpelier, Pioneer, Stryker, and West Unity accounted for a total of 11,884 people in 1980 (U.S. Bureau of the Census, 1981).

Agriculture and small industries are the mainstays of the economy. Corn, wheat, beans, and dairy cattle are produced. Local industries include metal finishing and manufacturing of toys, candy, automobile parts, and wood products. 
Topography ranges from flat to rolling. Altitudes range from about $680 \mathrm{ft}$ (feet) above sea level in the southeast to about $1,080 \mathrm{ft}$ above sea level in the northwest. The St. Joseph and Tiffin Rivers drain the County and flow southwest to the Maumee River, which, in turn, flows east-northeast into Lake Erie. This drainage pattern is controlled by the Wabash and Fort Wayne glacial end moraines.

Two subdivisions of the Central Lowlands physiographic province are represented in the County. Most of the County is made up of flat to hilly Till Plains, which contain end moraine, ground moraine, outwash, and alluvial material, and generally are poorly drained. The southeastern third of the County is flat Lake plains. This area is blanketed by poorly drained sand, silt, and clay-rich lake deposits (King, 1977).

The climate of Williams County can be characterized as temperate continental. Annual temperatures typically range from slightly below zero to the nineties. The mean annual temperature is $\mathbf{5 0 . 5}$ degrees Fahrenheit. The annual average precipitation of 34 in. (inches) includes an average of 27 in. of snowfall per year. Thunderstorms account for most of the summer rainfall. The growing season (from the last frost to the first freeze) is 156 days. Evaporation and transpiration often exceed rainfall by 10 in. in the months from May through September (King, 1977).

\section{Geologic Setting}

The rocks in Williams County consist of a series of consolidated rock formations capped by a layer or layers of unconsolidated sediments.

No bedrock is exposed in Williams County. The area is underlain by Mississippian and Devonian shales and sandstone. The rocks are very "tight;" that is, they have low porosity and permeability. Younger rocks were present in the County but were later eroded away (King, 1977). A generalized stratigraphic column of Mississippian and Devonian subsurface units for the area is shown in figure 5.

The rocks dip gently to the north-northwest at aout 20 feet per mile into the Michigan Basin. The Michigan Basin was formed during the Paleozoic Era, when massive amounts of sediments were deposited and later compressed into rock. The Michigan Basin and the Kankakee, Cincinnati, and Findlay Arches are the major structural features in the three-State area. There are several smaller anticlines and synclines (structural "wrinkles" or folds) in the bedrock. Little is known about the details of the local structures because not much subsurface information is available (King, 1977). Generalized bedrock geology of Williams County is shown in figure 6. 


\begin{tabular}{|c|c|c|c|c|c|}
\hline System & Series & Group & Formation & $\begin{array}{c}\text { Thickness } \\
\text { (feet) }\end{array}$ & $\begin{array}{l}\text { Lithologic } \\
\text { description }\end{array}$ \\
\hline \multirow{4}{*}{ Mississippian } & \multirow{4}{*}{ Kinderhookian } & & Cuyahoga Sh. & 272 & Mostly gray sh. \\
\hline & & & Sunbury Sh. & 25 & Brown to black fissile sh. \\
\hline & & & Berea Ss. & \multirow{2}{*}{38} & \multirow{2}{*}{$\begin{array}{l}\text { Impure quartz ss. with sh. } \\
\text { sh. partings underlain } \\
\text { by soft to hard gray } \\
\text { siliceous sh. }\end{array}$} \\
\hline & & & Bedford Sh. & & \\
\hline \multirow{8}{*}{ Devonian } & $\begin{array}{c}\text { Upper } \\
\text { Devonian }\end{array}$ & & Ohio Sh. & 171 & $\begin{array}{l}\text { Soft to fissile, dark gray } \\
\text { to brownish black sh. } \\
\text { with ls. in lower part. }\end{array}$ \\
\hline & \multirow{7}{*}{$\begin{array}{c}\text { Middle } \\
\text { Devonian }\end{array}$} & \multirow{2}{*}{$\begin{array}{c}\text { Traverse } \\
\text { Group }\end{array}$} & Ten Mile Creek & 56 & \multirow{2}{*}{$\begin{array}{l}\text { Soft, dark gray, shaly ls. } \\
\text { and dark brown sh. } \\
\text { with some greenish sh. }\end{array}$} \\
\hline & & & Silica Fm. & 56 & \\
\hline & & Dundee Ls. & & 43 & $\begin{array}{l}\text { Light to medium buff } \\
\text { ls. with medium to } \\
\text { dark gray dol. near } \\
\text { the base. }\end{array}$ \\
\hline & & \multirow{4}{*}{$\begin{array}{l}\text { Detroit } \\
\text { River } \\
\text { Group }\end{array}$} & Anderdon Mbr. & 35 & \multirow{3}{*}{$\begin{array}{l}\text { Light to medium gray } \\
\text { ls. grading to } \\
\text { brown dol. }\end{array}$} \\
\hline & & & Lucas Dol. & 74 & \\
\hline & & & Amherstburg Fm. & 15 & \\
\hline & & & Sylvania Ss. & 44 & Very pure quartz ss. \\
\hline
\end{tabular}

\section{EXPLANATION}

Dol., dol. Dolomite

Fm. Formation

Ls., Is. Limestone
Mbr. Member

Ss., ss. Sandstone

Sh., sh. Shale

Figure 5.--Stratigraphic column of bedrock units for Williams County, Ohio (modified from King, 1977). 
The shape and altitude of the erosional surface on the top of the bedrock (fig. 7) can be inferred from logs of wells that penetrate the bedrock, although little information is available for some parts of the County. Relief on the bedrock surface amounts to several hundred feet. The highest bedrock elevations, as well as the highest land-surface elevations, are in the northwest. Two possible drainage channels or former valleys begin in the south-central part of the County and trend to the southwest and to the northeast. Because no rocks or sediments remain from the approximately 330-million-year period between deposition of the Lower Mississippian shales and the glacial materials of the Quaternary Period, a history of the erosional surface is difficult to determine. The valleys may be part of the Teays Stage drainage system, which drained the Great Lakes area before the general onset of glaciation approximately 2 million years ago (Stout and others, 1943).

The unconsolidated sediments in Williams County consist of glacial, lake, and stream deposits. The kinds and distributions of these deposits are shown in figure 6 .

Ice covered the area during the pre-Illinoian, Illinoian, and Wisconsin glaciations, each of which was several thousand years long. The pre-Illinoian glaciation took place about 175,000 years ago, and the Wisconsin glaciation ended approximately 13,000 years ago. The Illinoian and Wisconsin glaciations destroyed evidence of the pre-Illinoian glaciation. The thickness and kinds of deposits left by the ice are the result of the thickness of the ice, the rate of advancement and retreat of the ice, the character of the underlying land, the material carried by the ice, and erosion after the ice left the area. The thickness of the glacial deposits in Williams County ranges from less than 80 feet in the southeastern part of the County to over $320 \mathrm{ft}$ in the northwest (King, 1977). Probable thickness of the unconsolidated sediments in Williams County is shown in figure 8.

The major glacial features are the Wabash and Fort Wayne end moraines. These end moraines, which formed on the edge of ice sheets as the sheets retreated, are made up of an unsorted mixture of till which is mostly clay with sands, gravel, and rock fragments deposited by the ice and lenses of silt, sand, and gravel deposited by meltwater.

To the southeast of each of the end moraines are ground-moraine deposits, which consist of sheets of debris (mostly till) left by the retreating ice. The ground moraines also contain lenses of sand and gravel, which were deposited by meltwater from the glacier and later covered with till. The lenses may be located on top of bedrock or at various levels in the till, and are up to $40 \mathrm{ft}$ thick. In a few places, the lenses are exposed at the surface.

The southeastern corner of Williams County is blanketed by sand, silt, and clay deposited by Lake Maumee. Lake Maumee contained glacial meltwaters trapped between the Fort Wayne and other moraines and the retreating ice sheet. At its highest level, Lake Maumee was about $200 \mathrm{ft}$ higher than modern Lake Erie. As the lake drained 

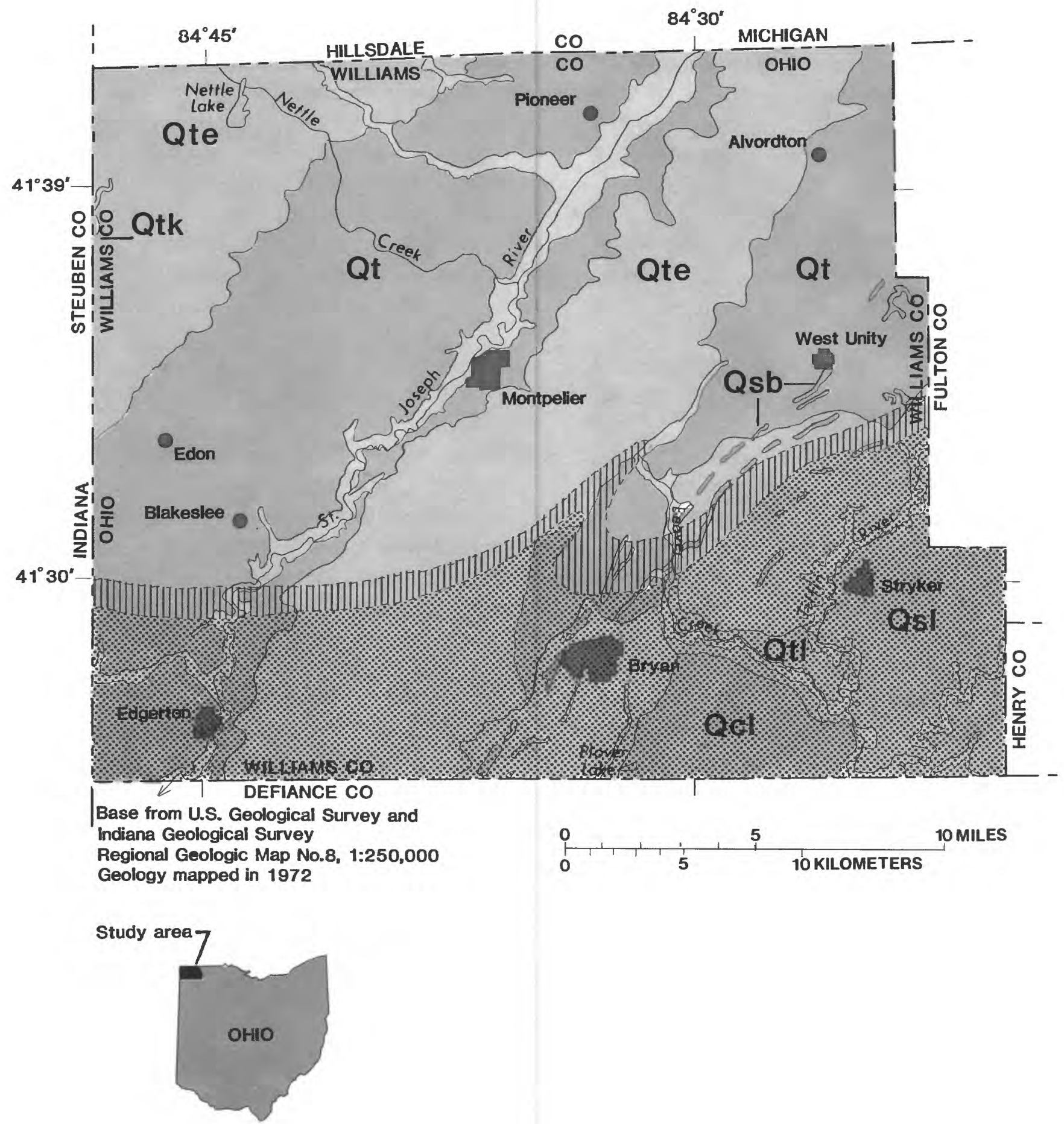


\section{CORRELATION OF MAP UNITS}

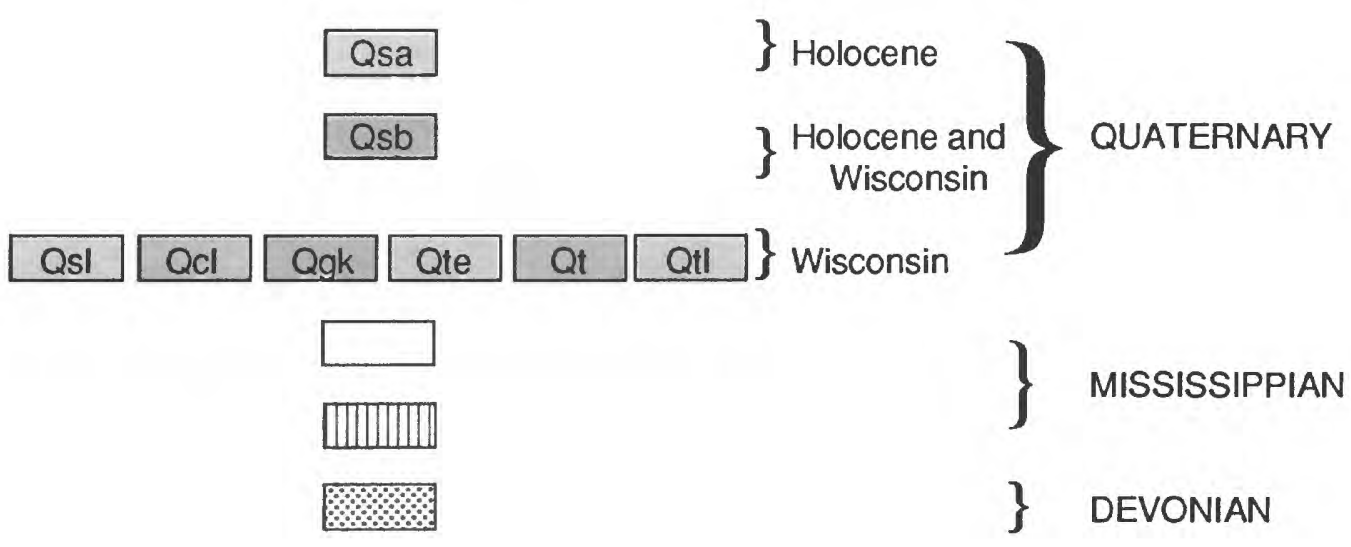

\section{DESCRIPTION OF MAP UNITS}

Unconsolidated Sediments

Qsa Sand, silt and gravel; alluvium and colluvium

Qsb Sand and gravel, some till; beach and shoreline deposits

QsI Sand, silt, and clay; lacustrine deposits

QCl Clay, silt, and sand; lacustrine deposits

Qgk Gravel, sand, some silt; kame deposits

Qte Till; mostly end moraine deposits

Qt Till; mostly ground moraine deposits

QtI Till; wave-scoured lake-bottom till

Bedrock Units

Cuyahoga Formation; shale

Berea Sandstone and Bedford Shale

Ohio Shale

Figure 6.--Distribution of bedrock and unconsolidated sediments, Williams County, Ohio. 


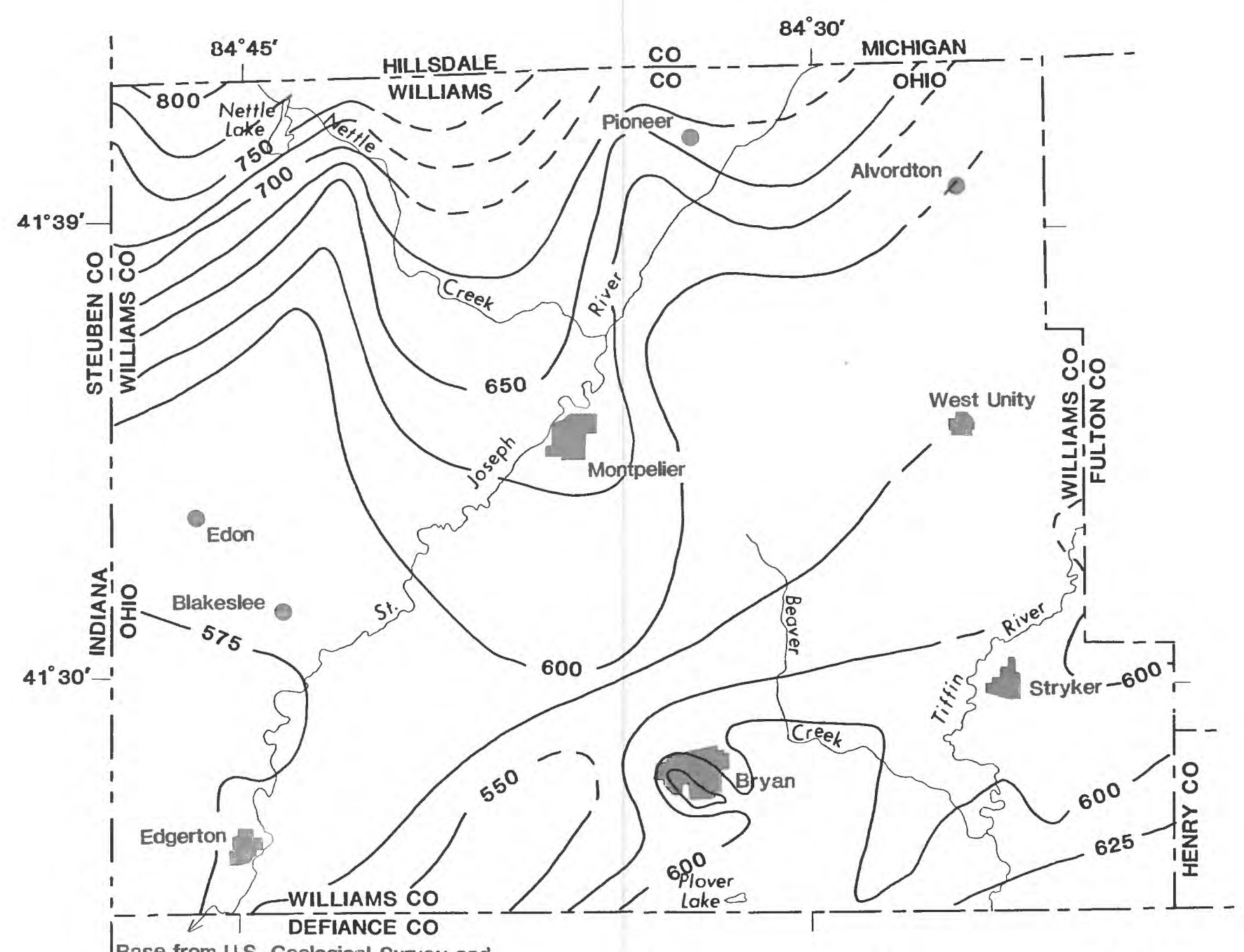

Base from U.S. Geological Survey and Indiana Geological Survey

Regional Geologic Map No.8, 1:250,000

Geology mapped in 1972
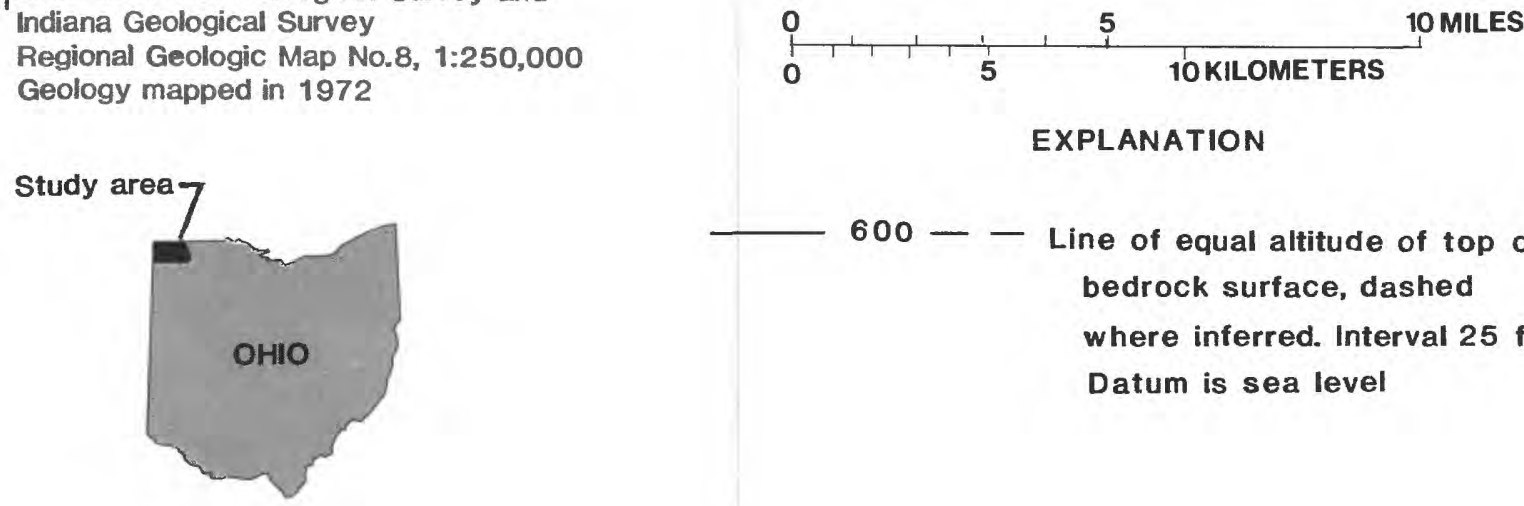

EXPLANATION

600 - Line of equal altitude of top of bedrock surface, dashed

where inferred. Interval 25 feet.

Datum is sea level

Figure 7.-Probable altitude of top of bedrock surface (after King, 1977, p.15.

and Baggett, 1987, p.15). 


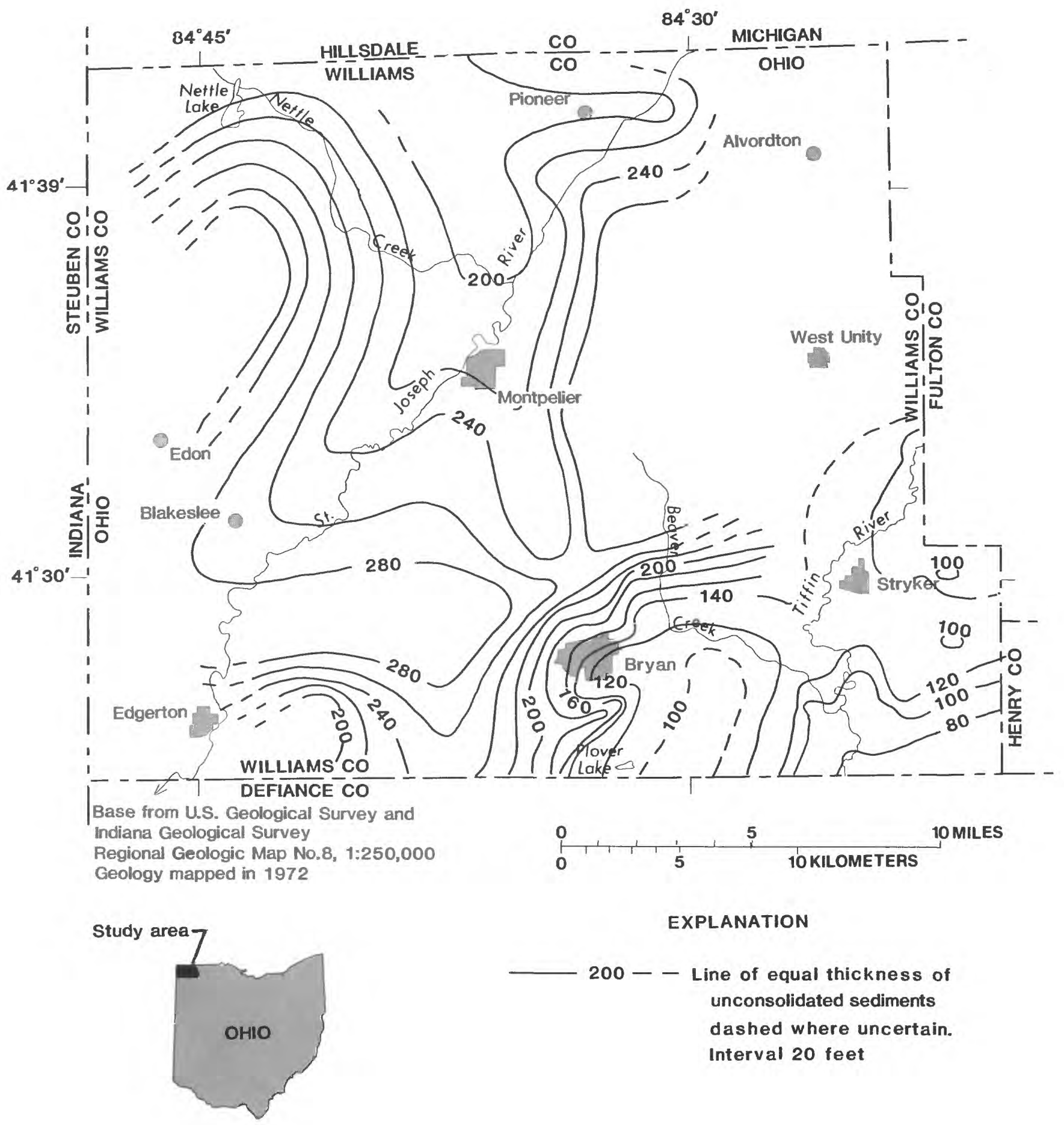

Figure 8.--Thickness of unconsolidated sediments in Williams County, Ohio (after King, 1977, p.15, and Baggett, 1987, p.15). 
through various outlets in the moraines, the water level of the lake fell, stabilized, and rose again several times. At each level, sandy beach ridges were deposited, many of which are still visible in the County. The lake also deposited sands and silts near the shore and silts and clays in deeper water. These lake sediments covered other glacial material already deposited. The area covered by the Lake Maumee sediments was poorly drained and became known as the "Black Swamp" (King, 1977).

Since the ice has retreated, streams and rivers have cut shallow valleys and floodplains and deposited alluvium consisting of sand, silt, and gravel.

The unconsolidated sediments in the area are discontinuous both vertically and horizontally, which can be seen in the generalized geologic sections of Williams County shown in figure 9 (in pocket). The sections were prepared from data recorded on several hundred well-drillers' logs on file at the Ohio Department of Natural Resources. Bedrock altitudes were determined from the top-of-bedrock map (fig. 7). The geologic sections illustrate that individual sand and gravel lenses are not continuous and sometimes cannot be traced from one well to another well only a few hundred feet away. The thickness of the lenses also differs greatly between some wells. Some reported differences may be due to inconsistencies in drillers' descriptions of similar material. The drillers' logs and geologic sections show that the two end moraines generally contain more sand and gravel than do the ground moraines and lake deposits. Much of the County has a 10- or 15-ftthick layer of clay at the surface. Most of the sand and gravel lenses are capped by a thin layer locally called "hardpan," that is, a layer of sand, gravel, and clay that is naturally cemented with calcium and is somewhat harder to drill through than is the underlying material. The geologic sections also indicate that, in many parts of the County, few wells penetrate the full thickness of the unconsolidated sediments. The extent and thickness of deeper sand and gravels is not known.

\section{GEOHYDROLOGIC FRAMEWORK}

A variety of physical properties of aquifers determines the amount and rate of movement of water through the ground. Aquifer properties have been determined at several places in the County through aquifer tests, which are conducted by pumping water from a well at a set rate for a number of hours or days. Drawdown is measured periodically at observation wells various distances from the pumping well. The pumping is then stopped and drawdowns are again measured periodically at all the wells as the water level recovers in the aquifers. Transmissivity and the storage coefficient can then be calculated by use of a series of equations.

Aquifer tests can sometimes detect changes or boundaries in the aquifer at some distance from the well being tested. This is noticed during the pumping when the cone of depression changes shape as it is enlarging. Transmissivities sometimes can be calcu- 
lated not only for the immediate vicinity of the well but also for a larger area or regional part of the aquifer. "Local" and "regional" transmissivities were calculated during some of the aquifer tests conducted on the north Bryan well field.

A simpler kind of aquifer test used to calculate the specific capacity of a well involves dividing the rate that a well is pumped by drawdown measured in the pumping well. For example, if a well is pumped at $10 \mathrm{gal} / \mathrm{min}$ (gallons per minute), and the water level drops $2 \mathrm{ft}$, then the specific capacity of the well is 5 . It is then assumed that this relation will hold for any pumping rate. Thus, if the well were pumped at $50 \mathrm{gal} / \mathrm{min}$, then the drawdown would be $10 \mathrm{ft}$. In general, the larger the specific capacity, the more transmissive the aquifer. This method does not take into account the length of pumping or the physical aspects of the well itself, but it does afford a rough estimate of productivity.

Short specific-capacity tests of this sort are usually done when a well is drilled. Pumping rate and drawdown are often recorded on well-drillers' logs, which are on file with the Ohio Department of Natural Resources. In Williams County, wells are often drilled only as far as necessary to obtain an adequate yield for the desired use. Many wells do not penetrate all of the unconsolidated sediments, but stop short of the sand and gravel layer found near the bedrock in some areas, a layer that often supplies large amounts of water. Therefore, in some areas, specific capacities calculated from logs may not give a true picture of the potential yield at a given site.

\section{Aquifers}

\section{Unconsolidated Sediments}

The unconsolidated sediments in Williams County are diverse in their composition, the manner in which they were deposited, and their distribution. These materials were deposited, reworked, and eroded from time to time by glaciers, lakes, and rivers; they are distributed, not in widespread homogeneous layers like the bedrock below, but more randomly in unsorted blankets of till, in piles of end moraine and ground moraine, and in sheets and ribbons of lake and stream deposits. Throughout all are small lenses of sand and gravel. In many places, there appears to be a layer of sand, gravel, and broken rock at the bottom of the unconsolidated deposits (that is, at the top of bedrock). Each kind of deposit, whether glacial, lake, or river, has different physical properties and will store, transmit, and release water differently.

Almost all of the usable ground water in Williams County is in the sands and gravels. The lenses and layers are discontinuous, as figure 9 illustrates. Hydraulic conductivity differs over small distances in unconsolidated materials, but because of the common glacial origin of the deposits in Williams County, hydraulic conductivities may be 
fairly similar among these sand and gravel lenses. The sand and gravel thicknesses, however, differ considerably, which, in turn, affects transmissivity and well yield.

Transmissivities of sands and gravels from eight aquifer tests in Williams County range from 2,800 to $64,300 \mathrm{ft}^{2} / \mathrm{d}$ (feet squared per day). Most of the transmissivities are less than $13,400 \mathrm{ft}^{2} / \mathrm{d}$. These transmissivities indicate productive aquifers similar to productive glacial aquifers in other parts of the midwestern United States. Transmissivity values do not, however, indicate the areal extent of an aquifer. Aquifer-test locations and transmissivity values are given in table 3 .

Storage coefficients for the sand and gravel aquifers calculated from the same aquifer tests also are listed in table 3 . The values range from 0.0001 to 0.00038 , which indicates that the sand and gravel beds are confined or semiconfined. Although clay and till are usually fairly impermeable, weathering can increase their permeabilities.

Specific capacities were calculated from logs for 121 wells, each over 100 feet deep, located in the south-central part of Williams County (Baggett, 1987). Usually, specific capacities for small domestic wells range from less than 1 to about $10 \mathrm{gal} / \mathrm{min} / \mathrm{ft}$ (gallons per minute per foot) of drawdown. Values for the City of Bryan's five large municipal wells, which are completed in sand and gravel just above the shale bedrock, range from 12 to $105 \mathrm{gal} / \mathrm{min} / \mathrm{ft}$ of drawdown.

The remaining unconsolidated sediments in Williams County have physical properties not conducive to transporting a great deal of water. The glacial tills, although they contain a range of material, are unsorted. They can be somewhat porous, but there is enough clay and silt to keep the permeability low. When tills become weathered, they can become permeable enough to allow some water to move up from or down to the more permeable sand and gravel below. The hydraulic conductivities of tills in the midwest and northern plains generally range from 0.001 to $0.01 \mathrm{ft} / \mathrm{d}$ (foot per day). The average hydraulic conductivity of weathered tills in South Dakota was about twice as high $(0.02 \mathrm{ft} / \mathrm{d})$ as that of unweathered tills (Norris, 1963$)$. Williams County tills probably are similar to the weathered tills in South Dakota. The lacustrine deposits of fine sand and silt contain some water. The hydraulic conductivities are low because of the fineness of the material. The alluvial clays and silts deposited on floodplains are very fine and also have low hydraulic conductivities.

\section{Bedrock}

The many hundreds of feet of bedrock beneath Williams County are characterized by a wide range of water-bearing properties; however, very little water is easily available from the bedrock or currently is being used. The upper 150 to $500 \mathrm{ft}$ of bedrock consists of rocks of Mississippian and Devonian age that are almost entirely shale, which has very 
Table 3.--Transmissivity and storage-coefficient values from pump tests in Williams County, Ohio

$\left[\mathrm{ft}^{2} / \mathrm{d}\right.$, feet squared per day; ODNR, Ohio Department of Natural Resources]

\begin{tabular}{|c|c|c|c|}
\hline $\begin{array}{c}\text { Well or area } \\
\text { of test }\end{array}$ & $\begin{array}{l}1_{\text {Transmis- }} \\
\text { sivity } \\
\left(f t^{2} / d\right)\end{array}$ & $\begin{array}{l}{ }^{1} \text { Storage } \\
\text { coef- } \\
\text { ficient }\end{array}$ & $\begin{array}{l}\text { Source } \\
\text { of data }\end{array}$ \\
\hline $\begin{array}{l}\text { Test well, } \\
\text { sec. } 25 \text {, } \\
\text { Bridgewater Twp. }\end{array}$ & 6,680 & -- & ODNR, 1969 \\
\hline $\begin{array}{l}\text { Test well, } \\
\text { sec. } 25, \\
\text { Florence Twp. }\end{array}$ & 26,700 & .0001 & ODNR, 1969 \\
\hline $\begin{array}{l}\text { North Bryan } \\
\text { municipal } \\
\text { well field }\end{array}$ & $\begin{array}{c}4,380 \\
\text { to } \\
64,300\end{array}$ & -- & $\begin{array}{l}\text { 2Jones and Henry, } \\
\text { Ltd., } 1968\end{array}$ \\
\hline do. & 6,680 & .00038 & $\begin{array}{l}\text { 2Basic Design } \\
\text { Associates, } 1973\end{array}$ \\
\hline do. & 7,080 & .00025 & $\begin{array}{l}{ }^{2} \text { Basic Design } \\
\text { Associates, } 1975\end{array}$ \\
\hline do. & 12,400 & .00012 & $\begin{array}{l}\text { King, } 1977 \text {, using } \\
\text { data from Basic } \\
\text { Design Associ- } \\
\text { ates, } 1975\end{array}$ \\
\hline do. & $\begin{array}{c}2,800 \\
\text { to } \\
13,400\end{array}$ & .00037 & Baggett, 1987 \\
\hline $\begin{array}{l}\text { South Bryan } \\
\text { municipal } \\
\text { well field }\end{array}$ & $\begin{array}{l}3,340 \\
\text { to } \\
7,490\end{array}$ & $\begin{array}{l}.00014 \\
\text { to } \\
.00018\end{array}$ & Baggett, 1987 \\
\hline \multicolumn{4}{|c|}{$\begin{array}{l}1_{\text {Information on test methods and calculations for each pump }} \\
\text { test are in the references listed. To convert transmissivities } \\
\text { from feet squared per day to gallons per day per foot, multiply } \\
\text { by } 7.481 \text {. }\end{array}$} \\
\hline \multicolumn{4}{|c|}{$\begin{array}{l}\text { 2unpublished report on file with Bryan Municipal Light and } \\
\text { water Utilities, Bryan, Ohio. }\end{array}$} \\
\hline
\end{tabular}


low porosity and hydraulic conductivity. The hydraulic conductivity of shale along bedding layers is usually $0.0001 \mathrm{ft} / \mathrm{d}$ or less (Freeze and Cherry, 1979). Because of the deposition and chemistry of shale, its hydraulic conductivity is often much less for flow perpendicular to the bedding than for flow parallel to it. Ancient weathering of the upper layers of the shale, at the former erosional surface (the top of the bedrock), may have increased the hydraulic conductivity in some areas.

Beneath these shales are about 3,000 ft of various formations of limestones, dolomites, sandstones, and shales. These formations differ in their water-bearing properties, and some contain unpotable water. The bedrock aquifer closest to the surface that could be tapped for use in Williams County is the Dundee Limestone of Devonian age. It is used in other areas of Ohio. However, this 40 - $\mathrm{ft}$-thick bed is 200 to $900 \mathrm{ft}$ below the land surface and so far is not an economically attractive water source.

\section{Ground-Water Levels. Recharge, and Discharge}

The potentiometric surface in the unconsolidated sediments in Williams County is shown on the map in figure 10. The depth to the water surface was less than $75 \mathrm{ft}$ in all wells measured. In all parts of the County, except the area covered by the Fort Wayne Moraine, water levels generally were less than $30 \mathrm{ft}$ below the land surface. In the area covered by the Fort Wayne Moraine, water levels generally were between 30 and $75 \mathrm{ft}$ below the land surface. Water levels were near or at the land surface in some areas; in some cases, the wells were flowing.

If the confining layer above the aquifer is leaky, ground water may discharge at the surface as seeps or springs. This discharge may form swamps or lakes, or may enter streams. Plover Lake and Nettle Lake (fig. 1) and some other small lakes are partially fed by springs. Flowing wells seen during this study were near Nettle Lake, in Bryan, along Beaver Creek near Bryan, and in southern Hillsdale County, Michigan, north of Pioneer. Surface water also may seep down through the leaky confining beds and recharge, or enter, the aquifer.

In many areas, sandy till or small lenses of sand and gravel may be near the surface and above the aquifers tapped by wells. The lenses may contain small amounts of water. There may be unsaturated zones beneath the lenses, and water may slowly "leak" down. These lenses are called "perched" aquifers. The water table commonly found close to the surface may be the water level in a perched aquifer, or it may be the level in a shallow, more continuous aquifer.

The natural cycle of water-level fluctuations (pumping effects are not included here) is the result of the interplay of rainfall, climate, and land use. These factors affect the recharge and discharge of ground water. 


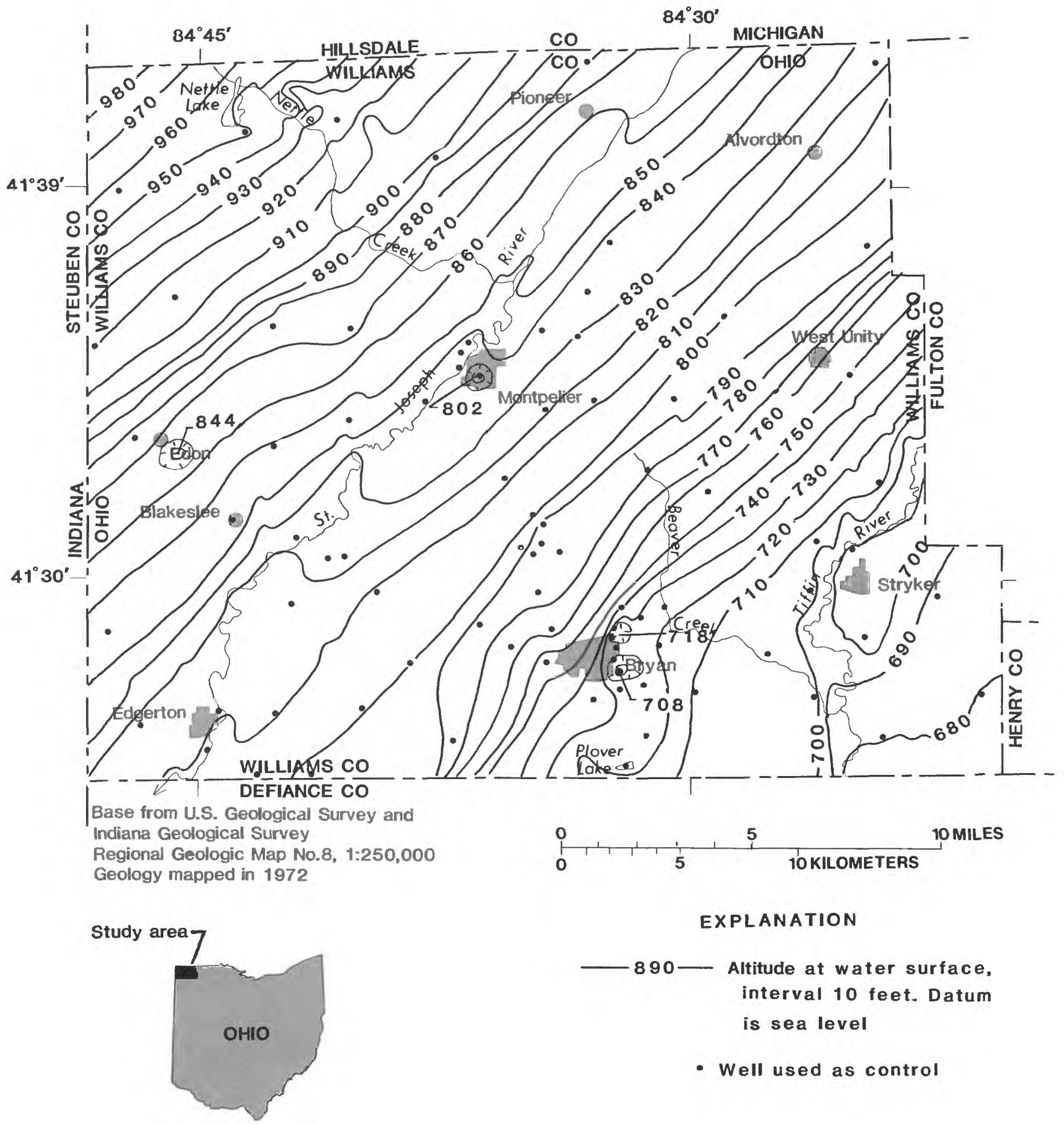

Figure 10.--Potentiometric surface of Williams County, Ohio, July 1985. 
Rain and snow are the sources of surface and ground water. Precipitation either soaks into the ground, evaporates, or runs off as streams and rivers. Hard, short rains such as thunderstorms produce more runoff than gentle, long rains, which allow more water to infiltrate the ground. Pavement, buildings, field drain tiles, impermeable soils, and steep slopes lessen infiltration and increase runoff. Vegetation and crops decrease infiltration. Permeable soils and gentle slopes lessen runoff and increase infiltration.

Vegetation also draws water from the soil. Hot weather increases the evaporation of water from the surface, plants, and the upper layers of the soil. Any water infiltrating the ground that does not evaporate and is not used by plants can percolate down and recharge the ground water.

In Williams County, except for wells affected by pumping, water levels in most of the measured wells fluctuated less than $4 \mathrm{ft}$ during the 2-year study. Levels were highest in late spring and lowest in late fall, as is shown in the well hydrographs in figure 11. (Locations of the selected wells are shown in figure 12.) The wells range from 15 to 170 $\mathrm{ft}$ deep. Spring rains and snowmelt take time to percolate down and raise water levelsmore than a month will elapse in the deeper sand and gravel aquifers. Water levels drop in summer because the amount of rainfall usually is less than the amount of evaporation plus transpiration. Freezing weather in the fall and winter ties up much precipitation as snow until spring, but the cold temperatures also slow evaporation and transpiration, and water levels start a slow recovery. Well WM-12, which is close to the St. Joseph River near Blakeslee, shows the effect of recharge more quickly, probably because of infiltration of water from the river.

Comparison of precipitation records from the 2-year study of Williams County with long-term records for northwestern Ohio shows that the rainfall total of 31 and $38 \mathrm{in.per}$ year for 1985 and 1986 is close to the yearly average of $34 \mathrm{in}$. Both summers were slightly wetter than average.

Recharge of water in the aquifers in Williams County comes from two principal sources. About half of the recharging water flows into the County as ground water. The recharge area includes Williams County and the area just to the northwest in Branch and Hillsdale Counties, Michigan, and in Steuben County, Indiana. The area northwest of the County is a topographic high and contains the headwaters of several rivers that flow to Lake Michigan or to Lake Erie. There are many lakes, and ground-water levels appear to be near the surface.

The second source of recharge is precipitation that falls inside the County that infiltrates the ground and eventually reaches the aquifers. The greatest amount of recharge by infiltration takes place on the two end moraines. Here, the permeable sands and gravels may be at or closer to the surface than in other areas. Soil studies also have shown that many of the soils derived from end moraines are more permeable than soils derived from ground moraines or lake deposits (U.S. Department of Agriculture, 1978). 

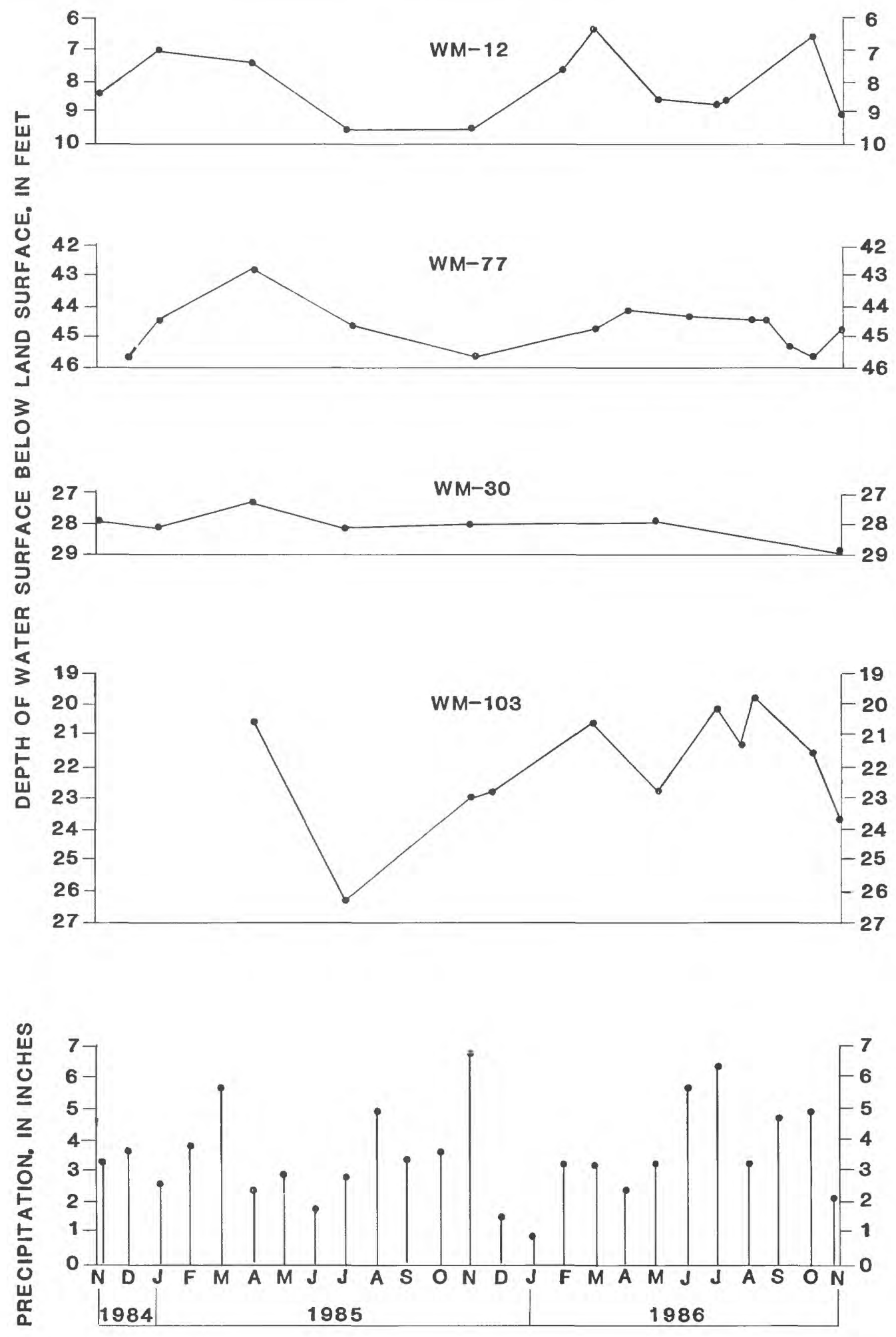

Figure 11.--Hydrographs of water levels in selected wells and of precipitation in Williams County, Ohio, November 1984 through November 1986. 

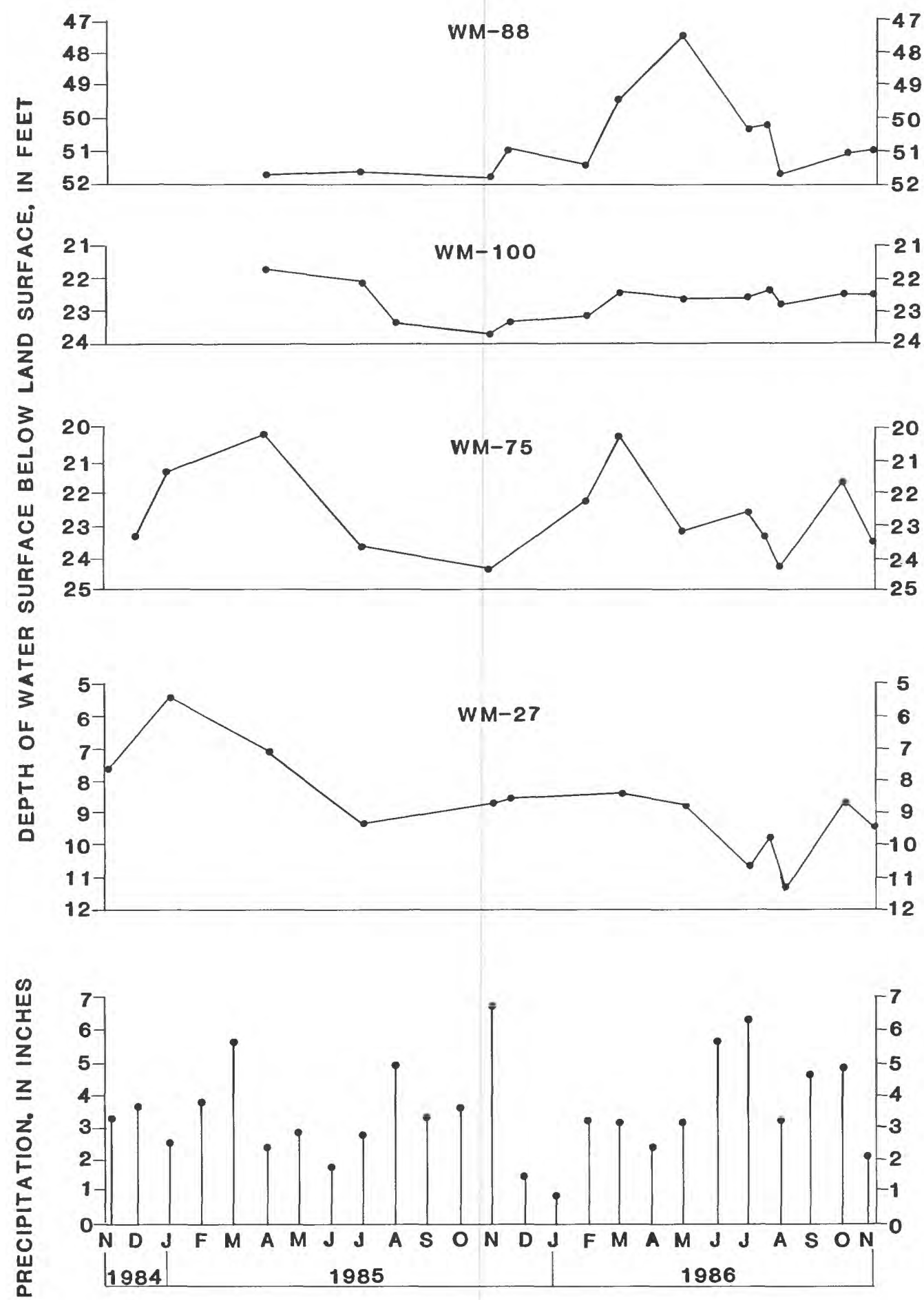

Figure 11.--Hydrographs of water levels in selected wells and of precipitation in Williams County, Ohio, November 1984 through November 1986---Continued. 

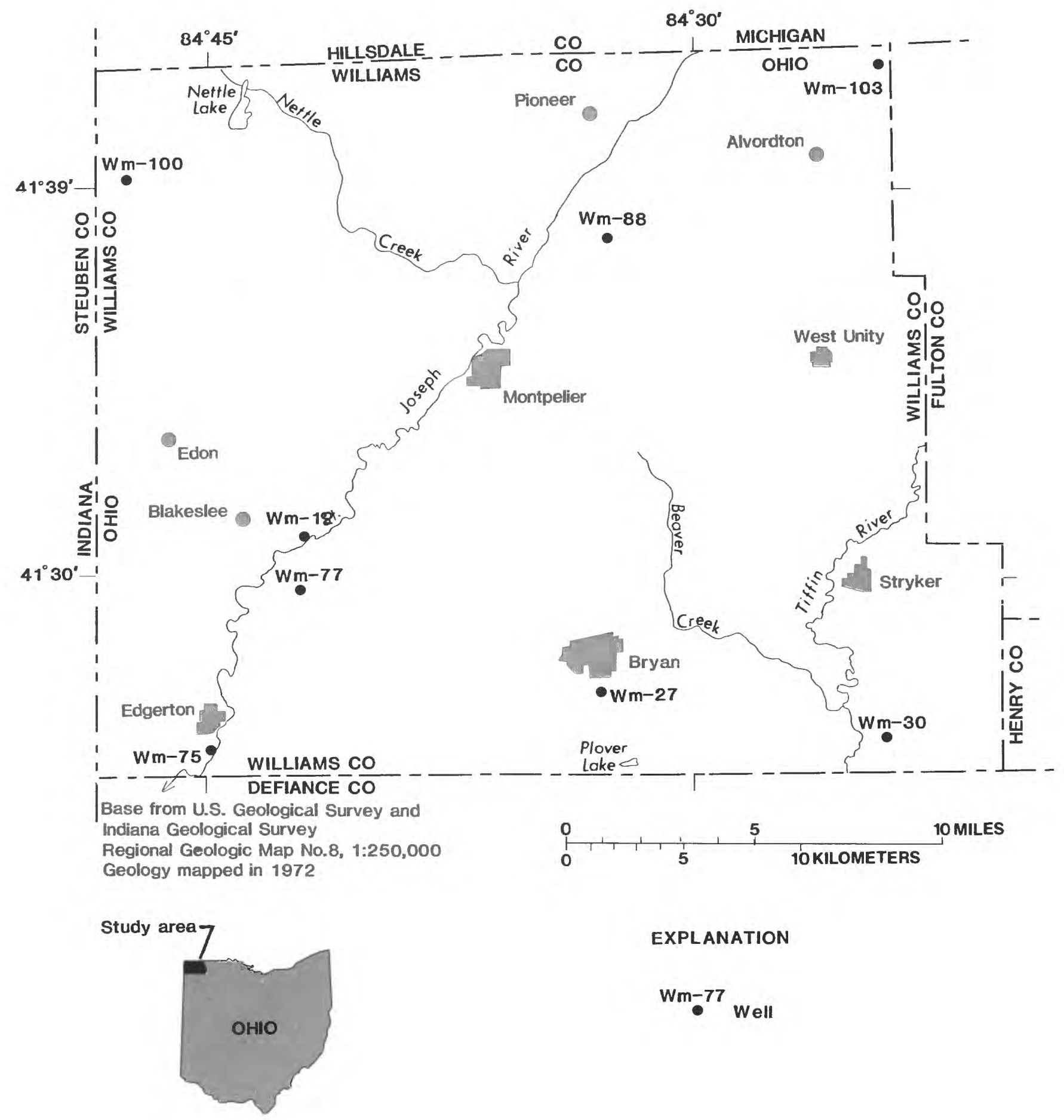

EXPLANATION

Wm-77 well

Figure 12.--Location of wells for which hydrographs are shown in Figure 11. 
Water leaves the ground-water system in several ways. Most of the ground water discharges into streams. A small amount is removed by pumping. The water can come from seeps or springs or enter the stream directly through the streambed. Ground-water levels adjacent to most of the streams and lakes are higher than water levels in the streams; thus, ground water flows slowly but steadily into the stream. This is shown on the potentiometric-surface map (fig. 10) and in the geologic sections (fig. 9).

The part of the streamflow that comes from ground water is called base flow. Pettyjohn and Henning (1977) have estimated that between 35 and 80 percent of a stream's yearly flow is base flow. The proportions of base flow and surface runoff in any stream varies throughout the year. During winter or long dry spells, most or all of the water in a stream may be base flow. During spring or rainy weather, most streamflow is likely surface runoff. When stream levels are very high, streams that normally gain ground water may, instead, temporarily recharge the aquifer below.

Shallow ground water also can be lost to transpiration by plants and by evaporation, particularly during hot weather. Some ground water, following the regional flow patterns, continues moving through the glacial aquifers to the southeast.

\section{Ground-Water/Surface-Water Relations}

A stream gain/loss study was conducted on November 6 and 7, 1986, to determine if the streams in Williams County are receiving water from or discharging water to the aquifers below. Discharge on six streams, Nettle Creek, Eagle Creek, Bear Creek, Mill Creek, Beaver Creek, and Prairie Creek, was measured. Locations of the measurement sites, as well as discharges and drainage areas, are shown in figure 13. Drainage areas for the sites ranged from 2.83 to $44.8 \mathrm{mi}^{2}$. The study was done during a time of low flow. At low flow, there is very little if any runoff in the stream, and any gain or loss would be a larger percentage of the total flow and would be easier to detect than at times of high flow. The stream hydrograph is flat-that is, the discharge is steady or changes very little over time. Base-flow conditions were determined by checking for steady streamflow after periods of at least 2 weeks without rain. Discharge measurements were made at four to seven places on each stream, and all measurements on each stream were done by one person on the same day. Suitable conditions were found in November 1986. Before and after the study, the flow in Beaver Creek at County Road C was measured and changed by less than 1.5 percent over 48 hours. The steady flow indicates a flat recession (little if any runoff contributing to the stream), and that the measured changes in discharge between sites on a stream are not due to time.

The six streams measured in the gain/loss study all either gained water or maintained constant discharges over the reaches measured, that is, water from the groundwater system was discharging into the streams. Discharge increased as the drainage area increased at progressively downstream sites on each stream. Some changes in discharge 


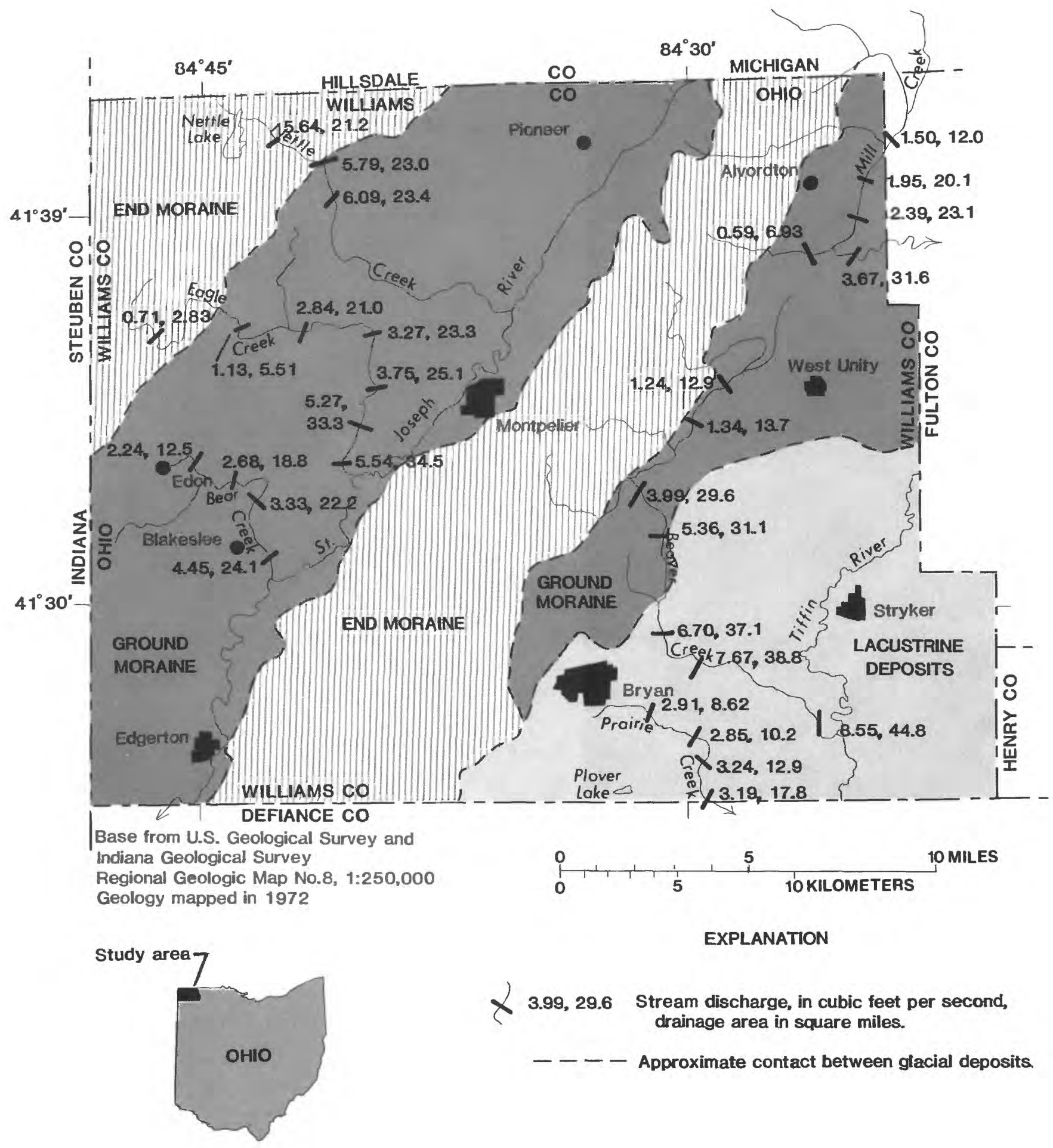

Figure 13.--Stream gain / loss study sites, stream discharge, and stream drainage areas. 
were smaller than the 5-percent margin of error of the measurements and cannot be accurately interpreted.

Most of the stream segments measured were flowing across ground-moraine sediments. Many of the stream segments that flow across end moraines and were flowing earlier in the year were dry during the study and could not be measured. The dry segments were mainly the headwaters of the stream, where drainage areas are very small. This could indicate losing streams, and that some parts of the end moraines are recharge areas for the aquifers below. Reaches of the streams that flowed across the finer grained lacustrine deposits gained less water than the reaches that crossed coarser groundmoraine deposits. Prairie Creek, which flows across fine-grained lacustrine deposits, gained about $0.03\left(\mathrm{ft}^{3} / \mathrm{s}\right) / \mathrm{mi}^{2}$ (cubic foot per second per square mile). Eagle Creek, which flows across coarser ground-moraine deposits, gained $0.15\left(\mathrm{ft}^{3} / \mathrm{s}\right) / \mathrm{mi}^{2}$. Beaver Creek, which flows across coarser ground moraine, wave-scoured till, and alluvium deposits, gained about $0.23\left(\mathrm{ft}^{3} / \mathrm{s}\right) / \mathrm{mi}^{2}$.

\section{GROUND-WATER AVAILABILITY}

\section{Well Yields}

Information on well yields was compiled from a review of previous studies and aquifer tests and by calculating specific capacities from well logs.

\section{Unconsolidated Sediments}

The most abundant ground-water supplies are in the unconsolidated sediments that cap the bedrock in Williams County. Yields of more than $500 \mathrm{gal} / \mathrm{min}$ are possible from properly constructed wells. Sand and gravel lenses and beds with this kind of yield are most common where the glacial deposits are thickest. Yields of 1,000 gal/min have been reached by several municipal wells. High-yielding supplies tap beds close to the contact with the bedrock below. The sands and gravels seem to be thicker and cover a larger area laterally in the end-moraine deposits than in the ground moraines. Where the glacial deposits are very thick, however, little is known about the composition of the lower part of the deposits.

The sand and gravel deposits become less widespread and are smaller in size (and the corresponding well yields decrease) toward the southeastern part of the County, where the surficial deposits are thinnest and contain more fine-grained material. In the extreme southeast, wells usually can be developed that are adequate for domestic use, but they often are drilled a few feet into the shale below to provide a reservoir for the pump 
to draw from. Where sand and gravel lenses are located, yields of $25 \mathrm{gal} / \mathrm{min}$ or less are obtained (Ohio Department of Natural Resources, 1959).

About 80 percent of the wells in Williams County produce from within 50 to $130 \mathrm{ft}$ of the surface (King, 1977). However, because of the heterogeneity of the surficial deposits, new wells occasionally may have to be drilled deeper than $130 \mathrm{ft}$ or abandoned and restarted at a different location to obtain an adequate yield of water.

\section{Bedrock}

Very little water is produced from the shales underlying Williams County. A few wells in the southern part of the County produce small (less than $5 \mathrm{gal} / \mathrm{min}$ ) amounts of water for domestic use. In this study, no wells were found that produce water from bedrock formations deeper than $200 \mathrm{ft}$, such as the water-bearing Dundee Limestone. However, in the summer of 1988 , a test well completed in the limestone to a depth of about $500 \mathrm{ft}$ was reportedly pumped at $240 \mathrm{gal} / \mathrm{min}$ for 24 hours. The well was drilled in the extreme southeastern corner of Williams County, about $4 \mathrm{mi}$ (miles) southeast of Stryker (Corrections Commission of Northwest Ohio, written commun., 1988). Unless water demands or the economics of water production change drastically, the deep bedrock aquifers probably will remain untapped.

\section{Effects of Pumping}

In 1983, about 3 percent of the ground water was withdrawn for use by pumping. Some of the water withdrawn by pumping may eventually return to the ground-water system; for example, some of the water used for irrigation or discharged through septic fields infiltrates the ground. Some of the water (such as water released by municipal treatment plants and industries) is discharged into streams and rivers after use. Table 4 shows the quantities of water withdrawn for public-supply, commercial, industrial, and rural-domestic uses. Williams County residents used 1.65 billion gallons of water in 1983.

Withdrawing water from a well lowers the water level in the aquifer around the well and causes the formation of a cone of depression. The area affected by the pumping depends on several factors-the size of the well, the rate and length of time that water is pumped from the well, and the properties of the aquifer.

In most rural parts of Williams County, pumping water for domestic use causes few problems. The drawdowns measured during this study after 20 to $30 \mathrm{~min}$ of pumping at $5 \mathrm{gal} / \mathrm{min}$ (before water-quality sampling of 40 of the wells) generally were $5 \mathrm{ft}$ or less. In most cases, water levels recovered fully in a few minutes. 


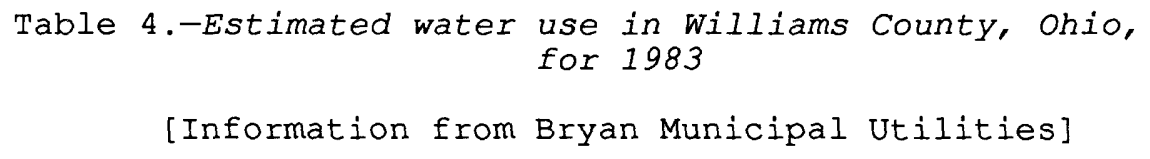

\begin{tabular}{lrrr}
\hline Type of use & $\begin{array}{c}\text { Daily use } \\
\text { (gallons) }\end{array}$ & $\begin{array}{r}\text { Annual use } \\
\text { (gallons) }\end{array}$ \\
\hline Municipal public supplies & 2.98 million & 1.09 billion \\
Commercial and industrial & .17 million & 62 million \\
Rural domestic & 1.37 million & 500 million \\
& 4.52 million & & 1.65 billion
\end{tabular}

In some parts of the southeastern corner of the County, and in other areas where less productive water supplies are used for homes, well drawdowns can be a problem. Some well owners report that water uses such as large loads of laundry need to be spaced throughout the day to allow water levels to recover.

Large municipal wells for the communities in Williams County can affect water levels over a large area. The drawdowns measured at wells in two villages were more than $40 \mathrm{ft}$, and the cone of depression at a well in a third village was, although shallower, more than $2 \mathrm{mi}$ in diameter. Changes in water levels such as these can affect the wells of private landowners several miles away. The effect of pumping varies with pumping rates and pumping schedules, and with seasonal variations in precipitation and aquifer recharge.

\section{GROUND-WATER FLOW}

Ground water flows from areas of high hydraulic head to areas of low hydraulic head. The contours on a potentiometric-surface map represent lines of equal hydraulic head. Ground-water movement is perpendicular to the contour lines on the potentiometric-surface map, from the high altitudes or heads to the low altitudes or heads. The slope of the potentiometric surface, or the change in head per unit of distance, is called the hydraulic gradient.

The ground-water flow in an aquifer depends on the hydraulic gradient on the water and on the hydraulic conductivity of the aquifer. The flow of water, in $\mathrm{ft} 3 / \mathrm{d}$ (cubic feet per day), that will move through an aquifer is equal to the hydraulic conductivity, in $\mathrm{ft} / \mathrm{d}$ 
(feet per day), times the hydraulic gradient, in $\mathrm{ft} / \mathrm{mi}$ (feet per mile), times the crosssectional area (in square feet) of the aquifer.

Ground water moves very slowly. Velocities usually range from $10 \mathrm{ft} / \mathrm{yr}$ to $10 \mathrm{ft} / \mathrm{d}$ (Todd, 1980). Velocities are faster near wells that are pumped as a result of an increase in the hydraulic gradient.

The direction of ground-water flow was determined from the water-level surface maps that were drawn using data from the County-wide well network. Although most of the field work for this study was done in Williams County, well logs and water levels also were obtained for some areas outside the County.

\section{Directions of Flow}

The general direction of ground-water flow in Williams County is from the northwest to the southeast. The potentiometric surface (fig. 10), which slopes to the southeast from about $980 \mathrm{ft}$ to about $680 \mathrm{ft}$ above sea level, represents a regional ground-water flow pattern. Water enters the ground-water system in Williams County or in a recharge area northwest of Williams County, flows mostly to the southeast through the County deep in the unconsolidated sediments, and discharges mostly to tributary streams of the Maumee River in Williams County and to the southeast.

The water-surface map also shows local ground-water flow patterns. Ground water closer to the surface flows toward and discharges into most of the streams in the County. On the map, discharge to streams is shown by contour lines that make a " $v$ " pointing upstream when they cross a stream. The water level in the ground is higher than the water level in the stream. In a few places, the water level in the ground is lower than the stream level. The stream "loses" water to the aquifer below. Stream losses are shown on the map by contour lines that make a " $v$ " downstream.

Across the middle part of the County, the regional flow pattern is modified by water entering the ground-water system from the Fort Wayne Moraine, which is just east of the St. Joseph River. This influx is represented in figure 10 as a small ridge or mound in the potentiometric surface. Some recharging water flows northwest toward the St. Joseph River, and some flows to the southeast as part of the regional flow.

Locally, cones of depression from several municipal well fields (shown in figure 10 as contours that make closed circles) modify the flow. The shape of the cones is not accurate on the map because of the scale of the map and the regional spacing of the wells in the measurement network. These low spots in the water surface are points of discharge (by pumping) from the aquifer. 
A generalized hydrogeologic section through Williams County showing regional and local flow patterns is presented in figure 14.

\section{$\underline{\text { Simulation of Flow }}$}

The ground-water system in Williams County is complex. The variety of the types of glacial deposits, the discontinuity of the many sand and gravel lenses in these deposits, and the lack of subsurface information for some parts of the deposits make understanding the ground-water system difficult.

A mathematical model of the ground-water system can help in understanding the system. A mathematical model is a simplified numerical representation of the groundwater system and is based on a conceptual model of how the ground-water system works. The various components of the system, such as the shape and properties of the aquifers or the amount of recharge, are determined or estimated. The conceptual model is generalized to make the mathematical model manageable, but the most important components of the ground-water system are considered so that the mathematical model represents observed conditions.

Information collected in the field is used as much as possible when constucting the mathematical model. When the mathematical model is run on a computer, a map of the potentiometric surface of the area is produced. The map is compared to the water levels measured in the field. If the simulated and measured water levels do not agree, some of the information used in the mathematical model is adjusted and the model is run again. This "calibration" process goes on until the simulated water levels are close to the water levels measured in the field.

Much can be learned about ground-water flow by simulating it with a mathematical model. Values for parameters that cannot easily be measured, such as hydraulic conductivity, can be estimated and tested in the mathematical model. Values also can be varied individually and the ground-water system's response or "sensitivity" to each parameter can be evaluated. A calibrated mathematical model also can be used to predict the ground-water system's response to changes such as increased pumpage. The assumptions and limitations of the mathematical model need to be kept in mind when drawing conclusions between results of the mathematical model and the actual ground-water system.

\section{Description of the Conceptual Model}

In the conceptual model of the ground-water system for the Williams County area, the entire group of unconsolidated sediments act as one unit on a regional scale. Water 


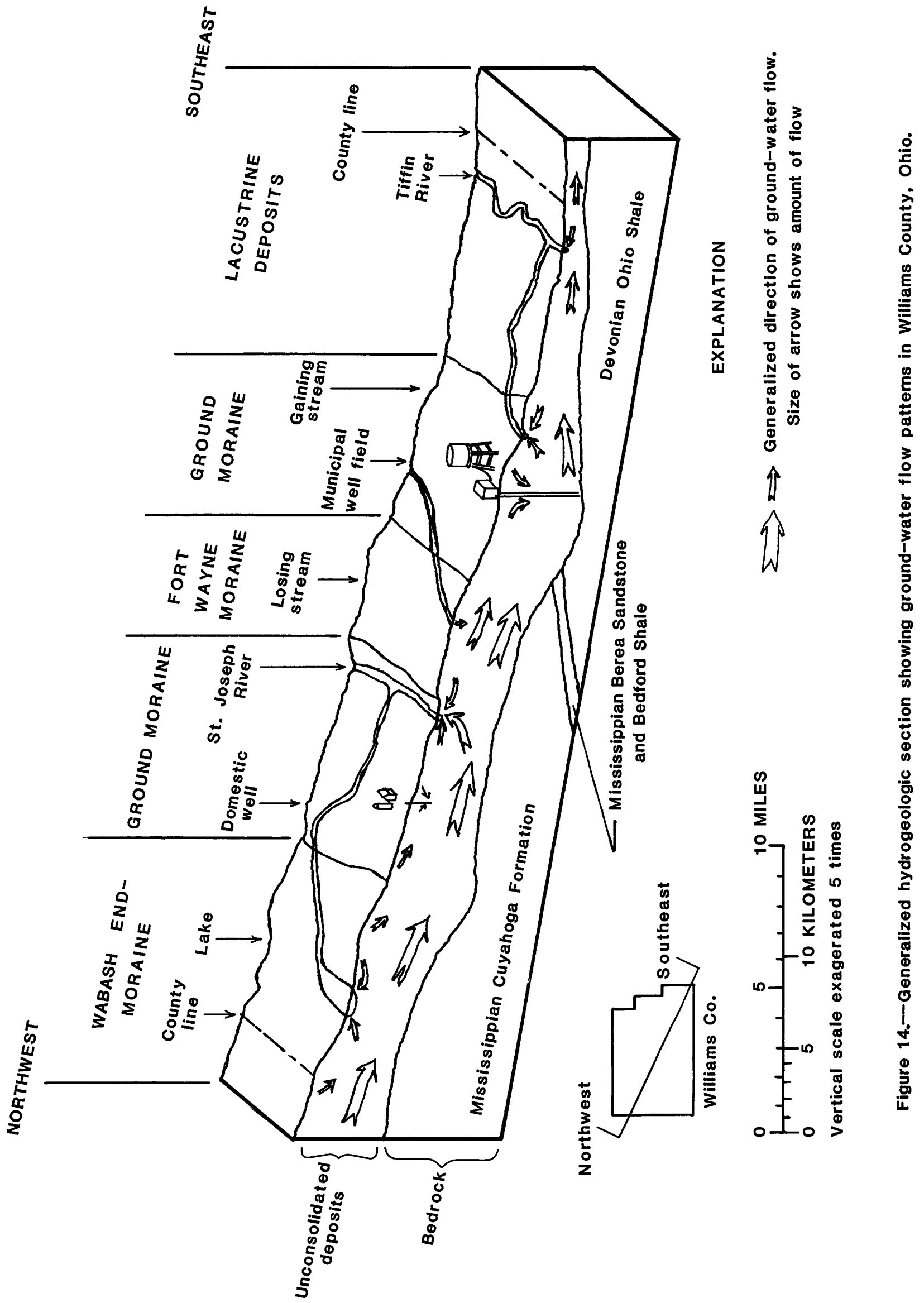


enters the flow system as precipitation. Any water that does not run off, is not used, or is not evaporated or transpired reaches the aquifer. The major recharge areas are just northwest of the County and the simulated area, although some recharge takes place over the entire area. A small amount of water seeps into the ground from losing streams, especially from the very small streams on the end moraines. Regional ground-water flow is southeastward through the simulated area, including Williams County. Local flow is toward streams. Most (about 88 percent) of the ground water is discharged to streams. Some water remains in the ground-water system as it leaves the County and the simulated area. Water also leaves the ground-water system as evapotranspiration and through withdrawal by pumping. Figure 15 is a representation of the conceptual model of the ground-water system in Williams County.

\section{Estimated Water Budget for the Williams County Area}

An estimated water budget for the ground-water system in the Williams County simulated area is shown in table 5. Estimates of recharge and discharge were calculated as follows:

- Ground-water flow into and out of the study area was calculated by use of Darcy's Law, on the basis of data from the potentiometric-surface map and the map showing thickness of unconsolidated sediments.

- Recharge values were calculated by use of Pettyjohn and Henning's (1977) hydrograph-separation techniques.

- Ground-water discharge to streams was estimated from low-flow data for the Tiffin and St. Joseph Rivers (Johnson and Metzker, 1981) and from the gain/loss stream-study data.

- Ground-water pumping information was provided by Bryan Municipal Utilities (Kevin Maynard, Bryan Municipal Light and Water Utilities, written commun., 1985).

The ground-water system is in steady state. On the average, the amount of water entering the system equals the amount of water leaving the system. If a large amount of water enters the system through recharge during a wet year, the water will either be discharged (as streamflow, for example), or the total amount of water in the system will increase and raise water levels in the aquifer. If discharge from the system increases (from increased pumping, for example, or from higher evapotranspiration), either more water will be drawn into the system (if available) or water levels will fall in the aquifer. An equilibrium will be reached and recharge will again balance discharge. 


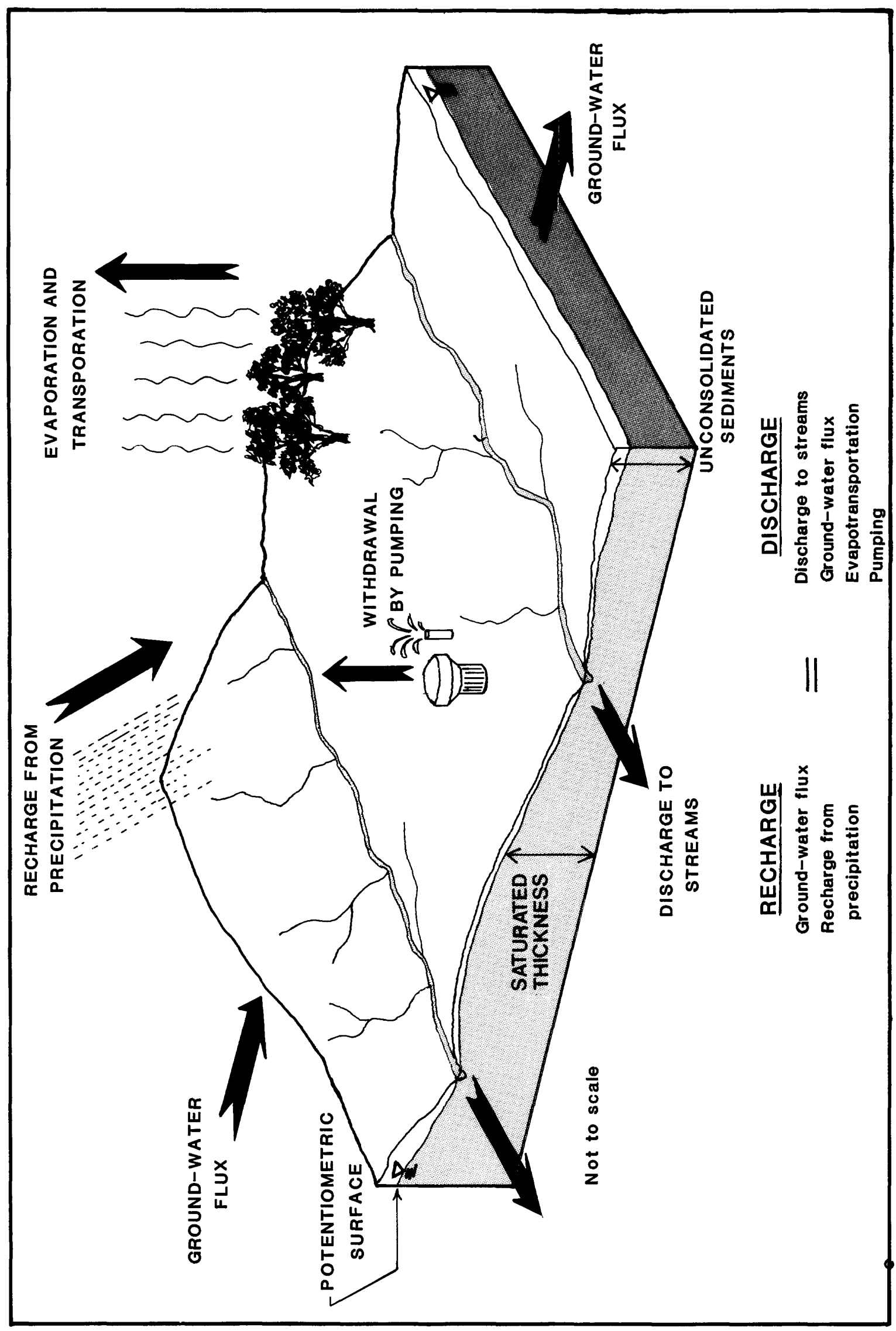

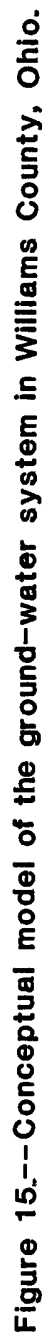




\begin{tabular}{|c|c|c|c|c|c|}
\hline $\begin{array}{l}\text { Type of } \\
\text { recharge }\end{array}$ & $\begin{array}{c}\text { Simu- } \\
\text { lated } \\
\text { re- } \\
\text { charge, } \\
\left(\mathrm{ft}^{3} / \mathrm{s}\right)\end{array}$ & $\begin{array}{c}\text { Esti- } \\
\text { mated } \\
\text { re- } \\
\text { charge, } \\
\left(\mathrm{ft}^{3} / \mathrm{s}\right)\end{array}$ & $\begin{array}{l}\text { Type of } \\
\text { discharge }\end{array}$ & $\begin{array}{l}\text { Simu- } \\
\text { lated } \\
\text { dis- } \\
\text { charge, } \\
\left(\mathrm{ft}^{3} / \mathrm{s}\right)\end{array}$ & $\begin{array}{l}\text { Esti- } \\
\text { mated } \\
\text { dis- } \\
\text { charge, } \\
\left(\mathrm{ft}^{3} / \mathrm{s}\right)\end{array}$ \\
\hline $\begin{array}{l}\text { Ground-water flow } \\
\text { into study area }\end{array}$ & 166 & 150 & $\begin{array}{l}\text { Ground-water flow } \\
\text { out of study area }\end{array}$ & 14 & 30 \\
\hline \multirow[t]{2}{*}{ Precipitation } & 175 & 160 & $\begin{array}{l}\text { Ground-water discharge } \\
\text { to streams }\end{array}$ & 322 & 273 \\
\hline & & & Ground-water pumping & 5 & 7 \\
\hline Total recharge & $\overline{341}$ & $\overline{310}$ & Total discharge & $\overline{341}$ & $\overline{310}$ \\
\hline
\end{tabular}

\section{Description and Construction of the Mathematical Model}

The mathematical model used in this study is the modular, three-dimensional, finitedifference ground-water flow model developed by McDonald and Harbaugh (1984). In this study, the model was used as a two-dimensional model. To simulate the groundwater system, the study area is divided into a grid of small, three-dimensional, six-sided blocks. Values for parameters (recharge, hydraulic conductivity, and so forth) of the ground-water system are assigned to each block in the mathematical model. The value for each parameter is constant for the entire volume of each block. The flow of ground water through each block can be in or out through each of the six faces on the block, and is determined by solving mathematical equations. Ground-water flow through the entire system is represented by the flow calculated in all of the blocks in the mathematical model.

Ground-water flow in the unconsolidated sediments in and surrounding Williams County was simulated for this study. These sediments were simulated as one layer for two reasons. First, although the sand and gravel lenses within the unconsolidated sediments are discontinuous and hard to correlate, the potentionmetric surface shows that the lenses are hydraulically connected and act as one unit. Secondly, there is not enough information available to separate units and to identify aquifer properties for each unit. In addition, this type of detail is not necessary to describe regional flow. The bedrock was not simulated as part of the active flow system. Most of the shale bedrock immediately under the unconsolidated sediments is relatively impermeable. No information was found that showed an appreciable flow in or out of the shale. As far as could be determined, any flow in or out of the bedrock would be insignificant when compared with the flow in the unconsolidated sediments above. 
The study area was broken into 2,025 blocks in a uniform grid of 45 rows and 45 columns. The grid (fig. 16, in pocket) is one layer thick. The blocks are $3,300 \mathrm{ft}$ on a side and have a surface area per block of $0.391 \mathrm{mi}^{2}$. The simulated area covers $791 \mathrm{mi}^{2}$. The blocks have no set thickness; rather, the thickness varies with the saturated thickness of the aquifer. The altitude of the bottom of the blocks is set equal to the approximate altitude of the top of the bedrock in the center of each block. The grid is aligned so that two sides of the grid are parallel to the regional flow direction, which is from northwest to southeast. The edges of the grid are turned about 45 degrees from the north-south and east-west political boundaries of Williams County.

In order to construct a mathematical model of flow in the unconsolidated sediments in Williams County, the following assumptions and simplifications have been made:

1. The aquifer as a whole is homogeneous and isotropic. Although individual sand and gravel bodies are not widespread, the unconsolidated deposits of each type are considered to be consistent in composition on a regional scale.

2. Ground-water flow in the aquifer is horizontal.

3. The hydraulic conductivities of the unconsolidated deposits are constant with depth but differ areally.

4. The vertical hydraulic conductivity is 100 times less than the horizontal hydraulic conductivity. This figure is derived from tests on clay from the Bryan municipal well field and from the literature (Todd, 1980, and Freeze and Cherry, 1979).

5. The ground-water system is in a steady state. The amount of water that enters the system (from precipitation and ground-water flux) equals the amount of water that leaves (by stream discharge, pumping, and groundwater flux) the system.

6. Streambeds are $1 \mathrm{ft}$ thick.

7. The ground-water system is simulated as an unconfined system. Local confined conditions are accounted for in the model.

8. Streams are simulated as drains. This means that ground water will discharge into a stream as long as the water level in the ground is higher than the water level in the stream. If the ground-water level drops below the stream level, the mathematical model will not show stream water 
discharging into the aquifer. The potentiometric-surface map and the stream gain/loss study show that almost all of the streams in Williams County are gaining streams. Some small streams are gaining such a small amount of water that they are not included in the model.

The simulated area includes an area outside Williams County because a mathem cal model should extend to the natural boundaries of the ground-water system if at all possible. Some of the natural boundaries of the flow system are far enough beyond th Williams County line that they cannot be used in the mathematical model. For examf similar geologic conditions continue for many miles to the northeast and southwest of County. Arbitrary boundaries parallel to ground-water flow lines were picked for eas constructing the model. The simulated boundaries do not coincide with the natural boundaries of the ground-water system in these cases.

The natural boundaries of the ground-water system are as follows:

- The lower boundary of flow is the bedrock below the unconsolidated sediments. Flow in or out of the bedrock is assumed to be small.

- The upper boundary to flow is either the free-water surface or leaky confining clays.

- A ground-water divide in the major recharge area is the boundary to the northwest of the simulated area.

- To the southeast, the unconsolidated sediments thin or are eroded away, and bedrock is exposed in places along the Maumee River. It is assumed that most of the remaining ground water discharges into the Maumee River. In some areas southeast of the County and the simulated area, the bedrock beneath the unconsolidated sediments is limestone of Devonian age. Ground water may flow into the limestone.

- To the northeast and southwest (the "sides" of the mathematical model or the direction perpendicular to the regional flow), the ground-water system extends for a long distance before reaching any physical boundaries. Ground-water flow follows, and does not cross, flow lines.

The flow-system boundaries used for the mathematical model are as follows:

- The lower boundary is bedrock and is assumed to be impermeable.

- The system is simulated as an unconfined system, and the upper boundary is thus the free-water surface. 
- The northwestern and southeastern edges of the grid are simulated as constant-flux (constant-flow) boundaries. These two boundaries have ground water flowing in or out across them. The amount of water entering or leaving the model was calculated using the formula for Darcy's Law, which states that the discharge for a block of aquifer is equal to the crosssectional area of the saturated thickness of the block times the hydraulic conductivity times the change in head (or gradient) across the block. For each block along the constant-flux boundary of the model, the thickness of the unconsolidated deposits, the hydraulic conductivity, and the hydraulic gradient from the potentiometric-surface map were calculated and used in the formula.

- The northeastern and southwestern sides of the grid are parallel to the regional flow lines. These boundaries are simulated as no-flow boundaries.

Individual characteristics of the ground-water system were simulated as follows:

- The bottom elevations of the unconsolidated sediments were input into the mathematical model, assigning a value to each block in the mathematical model. Information was based on bedrock-surface maps.

No surface elevations were input. Water levels could rise as high as necessary to let the simulated system reach equilibrium. Water levels above land surface were noted when the model-generated water levels were compared to land-surface and measured water-level data.

- Hydraulic conductivity also was entered, by use of a grid of values, so that rates could differ areally. A range of rates was determined from aquifer tests and from the literature, as previously explained. The simulated area was divided into regions of high, moderate, and low hydraulic conductivity that correspond approximately to the end moraine, ground moraine, and lacustrine deposits, respectively. Values were assigned to the three regions according to their estimated or measured hydraulic conductivities.

- Regional recharge rates for Ohio were calculated by Pettyjohn and Henning (1977), who used stream hydrograph-separation techniques to determine the relative amounts of ground-water base flow and surface runoff in the total flow of streams, and to determine average recharge rates for the river basins in Ohio. Recharge rates for the St. Joseph and Tiffin River basins ranged from 2 to 8 in. per year, depending on the amount of rainfall. This is the amount of precipitation that actually reaches the groundwater system. Water lost to evapotranspiration is not included, and thus is not part of the simulation. 
Recharge was input into the mathematical model by use of a grid to allow the rate to differ across the County. Areas of high, moderate, and low recharge were determined from U.S. Soil Conservation Service soil surveys, which give infiltration rates for the soils in the modeled area. Generally, the area of the Wabash Moraine has a high recharge rate, the area of the Fort Wayne Moraine has a moderate recharge rate, and the ground-moraine and lacustrine deposits have low recharge rates. Recharge rates were spread among the three areas so that the total volume of recharge was approximately equal to the volume calculated by Pettyjohn and Henning (1977).

- The hydraulic conductivity of the streambed is a factor in determining how much water exchanges from the stream to the aquifer below. Values for the streambed hydraulic conductivity were estimated from published values (Freeze and Cherry, 1979) after inspecting the streambed material. Values were entered for the St. Joseph and Tiffin Rivers and for the major tributaries.

- Major pumping centers incorporated into the model included all of the municipal well fields and some of the larger commercial and industrial wells. Pumping centers were simulated as a single well in a single block that withdraws water at the well field's average daily pumping rate from the aquifer. The well was located in the grid block that is closest to the center of the well field.

Withdrawals from all of the small domestic wells throughout the area were calculated by multiplying an average daily water use of $80 \mathrm{gal} / \mathrm{d}$ (gallons per day) times the rural population of 17,104 to get an average daily withdrawal of $1.37 \mathrm{Mgal} / \mathrm{d}$ (million gallons per day) (Kevin Maynard, Bryan Municipal Light and Water Utilities, written commun., 1985). This volume of water was then spread evenly among the blocks in the grid. The discharge from each block was very small. Most of the withdrawn water is returned to the ground-water system through individual septic systems; therefore, a value for rural domestic withdrawals was not included in the simulation.

\section{Calibration and Sensitivity Analysis}

The mathematical model was calibrated against the potentiometric surface measured from July 8 through 11,1985 . Initially, only the regional gradient was simulated. Constant-head blocks were placed along the northwestern and southeastern edges of the grid to simulate the actual water levels at these boundaries. These constant-head blocks keep 
the simulated hydraulic head at the specified level, but allow as much water as is needed to produce that hydraulic head to enter or leave the mathematical model. Values for recharge and hydraulic conductivity were constant for the entire grid. The stream grid was then added. A rough match of the hydraulic gradient was attained, although the total amount of water in the system did not match the water budget in table 5 .

The constant-head blocks were replaced with constant-flux blocks. These blocks allowed a specified volume of water to enter or leave the model, but let the hydraulic head in the block change. The fluxes or flows for the blocks were calculated by use of Darcy's Law, as previously explained. Differing values for hydraulic conductivities and recharge then replaced the uniform values for these parameters. Hydraulic conductivity, recharge, and streambed hydraulic conductivity were then adjusted until the simulated water levels closely matched the July 1985 measured water levels.

The simulated potentiometric surface is compared with the measured potentiometric surface in figure 17 (in pocket). In most areas, simulated water levels are within 5 or 10 $\mathrm{ft}$ of the measured levels. This is close to the accuracy of the well elevations on which the water levels are based.

The simulated water budget is shown in table 5. Water entering the simulated area is about evenly split between water falling as recharge in the simulated area and water that is already in the ground-water system. Most of the water leaves the simulated area as discharge to streams.

Changing the range of hydraulic conductivities changed the gradient of the water surface. By adjusting the conductivity values in the end-moraine, ground-moraine, and lacustrine deposits, the hydraulic gradients in these areas could be more closely matched by the mathematical model. When the hydraulic conductivity was changed in a constantflux block, the flux volume was recalculated. Hydraulic-conductivity values were varied from 10 to $100 \mathrm{ft} / \mathrm{d}$ in the low-conductivity (mostly lacustrine) areas, from 50 to $180 \mathrm{ft} / \mathrm{d}$ in the moderate-conductivity areas, and from 150 to $250 \mathrm{ft} / \mathrm{d}$ in the high-conductivity (mostly end-moraine) areas. The final values of 75,180 , and $220 \mathrm{ft} / \mathrm{d}$ are close to values derived from aquifer tests.

Changing the amount of recharge over the area did not have a large effect on the shape of the simulated potentiometric surface. It mainly raised or lowered the entire surface. Recharge values were varied from 1 to 4 in. in the low areas and from 3 to 9 in. in the high areas. Final values used were 2, 4, and 5, which fall in the range determined by Pettyjohn and Henning (1977).

Changes in the streambed hydraulic-conductivity values partially control the volume of water that leaves the simulated system as discharge to streams. This also causes local changes in the potentiometric surface by raising or lowering the surface a few feet near 
streams. Higher values let more water enter the streams and cause contour lines on the potentiometric-surface map to form larger " $v$ 's" pointing upstream than when lower values are used. Streambed hydraulic conductivity values were varied from 0.0001 to $10 \mathrm{ft} / \mathrm{s}$. Streambed thickness is assumed to be $1 \mathrm{ft}$. Final values for the streambed hydraulic conductivity were 0.1 to $1 \mathrm{ft} / \mathrm{s}$, the lower values corresponding to streams flowing across less permeable deposits. These values agree with values from the literature (Freeze and Cherry, 1979; Todd, 1980).

\section{Prediction of Effects of Hypothetical Pumping Scenarios}

Once the mathematical model was calibrated, several hypothetical wells and well fields were added to the simulation to show their effects on the simulated potentiometric surface. Wells that withdraw 2 and $5 \mathrm{Mgal} / \mathrm{d}$ of water were added to the simulation at various locations. This is a regional study, and grid blocks are $3,300 \mathrm{ft}$ on a side. Therefore, for well fields with wells spaced closer than $3,300 \mathrm{ft}$ apart, the wells were grouped together as one well and placed in the center of the block for purposes of simulation. The location of the test wells and the resulting simulated potentiometric surface are shown in figure 18 (in pocket). Simulated drawdowns are shown in figure 19.

Eight wells were added to the simulation. Locations for these hypothetical wells were selected to represent various geologic conditions, but otherwise were arbitrary. The pumping rates also were arbitrarily assigned, but are within a range of withdrawals typical of municipalities or industry. The potentiometric surface shown in figure 18 shows the effect on the existing water-level surface of withdrawals from all eight hypothetical wells. The total rate of pumping of the eight hypothetical wells exceeds total ground-water withdrawals in Williams County at the date of writing; such a pumping rate is not likely to be reached in the near future.

When water is pumped from a well, water levels are lowered in the area of the well. In figure 18 , this is shown by the shifting of the simulated-pumping water-surface contours to the left of the simulated water-surface contours. The greater the shift (the farther the distance between the lines), the more water levels are affected.

Wells A and B both have a simulated pumping rate of $2 \mathrm{Mgal} / \mathrm{d}$. Well $\mathrm{B}$ is located in an area of fine lacustrine deposits and lower hydraulic conductivities. The cone of depression for well $\mathrm{B}$ is narrower and deeper than the cones for the other wells. The average drawdown for the model block $(3,300 \mathrm{ft}$ on a side) containing well $\mathrm{B}$ is about $18 \mathrm{ft}$. The drawdown at the well would be more. The cones of depression for the other wells are broader and shallower because they are in coarser sediments having higher hydraulic conductivities. The average drawdown for the model block ( $3,300 \mathrm{ft}$ on a side) containing well $\mathrm{A}$ is about $12 \mathrm{ft}$. The drawdown at the well would be more. Water levels were lowered by more than $5 \mathrm{ft}$ for more than $1 \mathrm{mi}$ from wells A and B (fig. 19). 

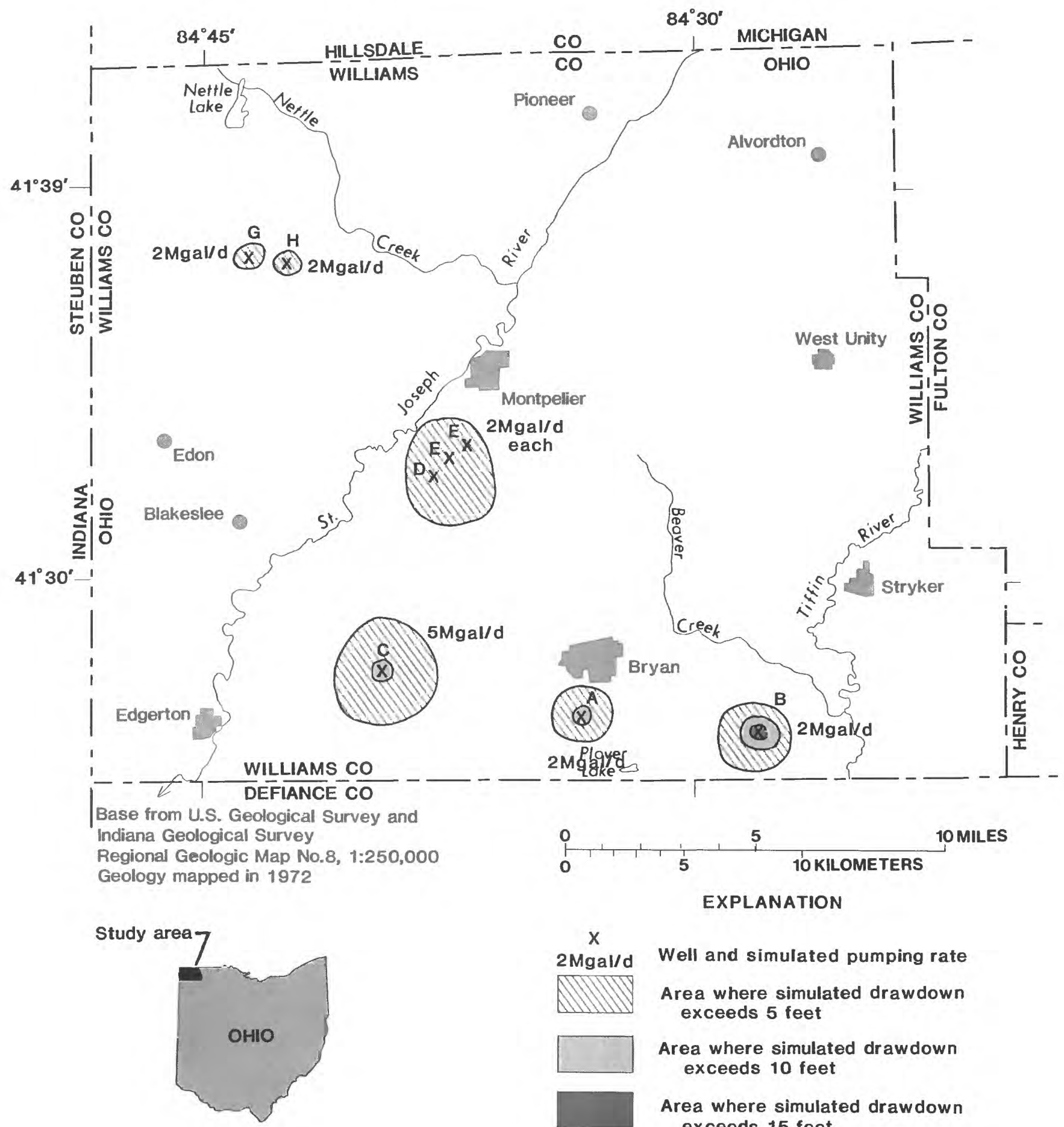

$x$

$2 \mathrm{Mgal} / \mathrm{d}$ Well and simulated pumping rate
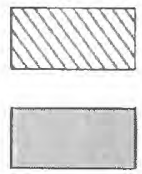

Area where simulated drawdown exceeds 10 feet

Area where simulated drawdown exceeds 15 feet

Figure 19.-- Simulated drawdowns for hypothetical wells in Williams County, Ohio. 
The area around well $\mathrm{C}$, which was simulated at $5 \mathrm{Mgal} / \mathrm{d}$, shows water levels being affected over a larger area than around well $\mathrm{A}$ because of the higher rate of pumping. The average drawdown for the model block ( $3,300 \mathrm{ft}$ on a $\left.\mathrm{s}^{*} \mathrm{de}\right)$ containing well $\mathrm{A}$ is about $12 \mathrm{ft}$. Water levels were lowered at least $5 \mathrm{ft}$ up to about $2 \mathrm{mi}$ away (fig. 19).

Wells D, E, and F, each simulated at $2 \mathrm{Mgal} / \mathrm{d}$, are aligned across the water-surface gradient and spaced 3,300 ft apart. The effects of pumping from each well overlap with each and form a large cone of depression (fig. 19).

The total effect of all eight of the hypothetical wells, on a regional scale, does not have a large effect on the ground-water system in Williams County. Locally, however, small or shallow wells, such as many of the domestic wells in Williams County, could be affected by large withdrawals, depending on the pumping rate and their distance from the new well. The size and shape of the cone of depression for a well of a particular size depends on the ground-water system properties at the location of the well. In this simulation, these properties are generalized over large areas. Thus, the effects of a 2-Mgal/d withdrawal at a location in the simulation may not be the same as those at another location. In addition, because of the assumptions and limitations of a mathematical model, the simulated effects of pumping may be different from the actual effects of a well at the same place in the field.

It is not the purpose of this simulation to predict withdrawal rates and drawdown effects for specific locations. However, the above examples give an idea of the possible effects of withdrawals after a well is installed and developed. Site-specific investigations would be needed before any new major well fields were developed.

\section{GROUND-WATER QUALITY}

Ground water in the unconsolidated sediments in Williams County generally is suitable for most uses. The water is hard, high in iron, and is primarily of the calcium and magnesium bicarbonate type except in the southeastern corner of the County, where the water contains more sodium. The general composition of the water samples is shown in a Piper water-quality diagram in figure 20. Water-quality data are presented in table 6 (at back of report). The maximum, minimum, median, and mean values for some major constituents are given in table 7. Table 8 (at back of report) explains some of the characteristics and constituents that affect water quality. Table 9 (at back of report) presents some methods of dealing with objectionable properties of water.

Calcium and magnesium are the major cations. The median concentrations for water in the 48 wells sampled were $67 \mathrm{mg} / \mathrm{L}$ (milligrams per liter) and $31 \mathrm{mg} / \mathrm{L}$, respectively. Sodium concentration ranged from 5 to $260 \mathrm{mg} / \mathrm{L}$, with a median value of 29 $\mathrm{mg} / \mathrm{L}$. The higher concentrations were mostly in the southeastern part of the County. 


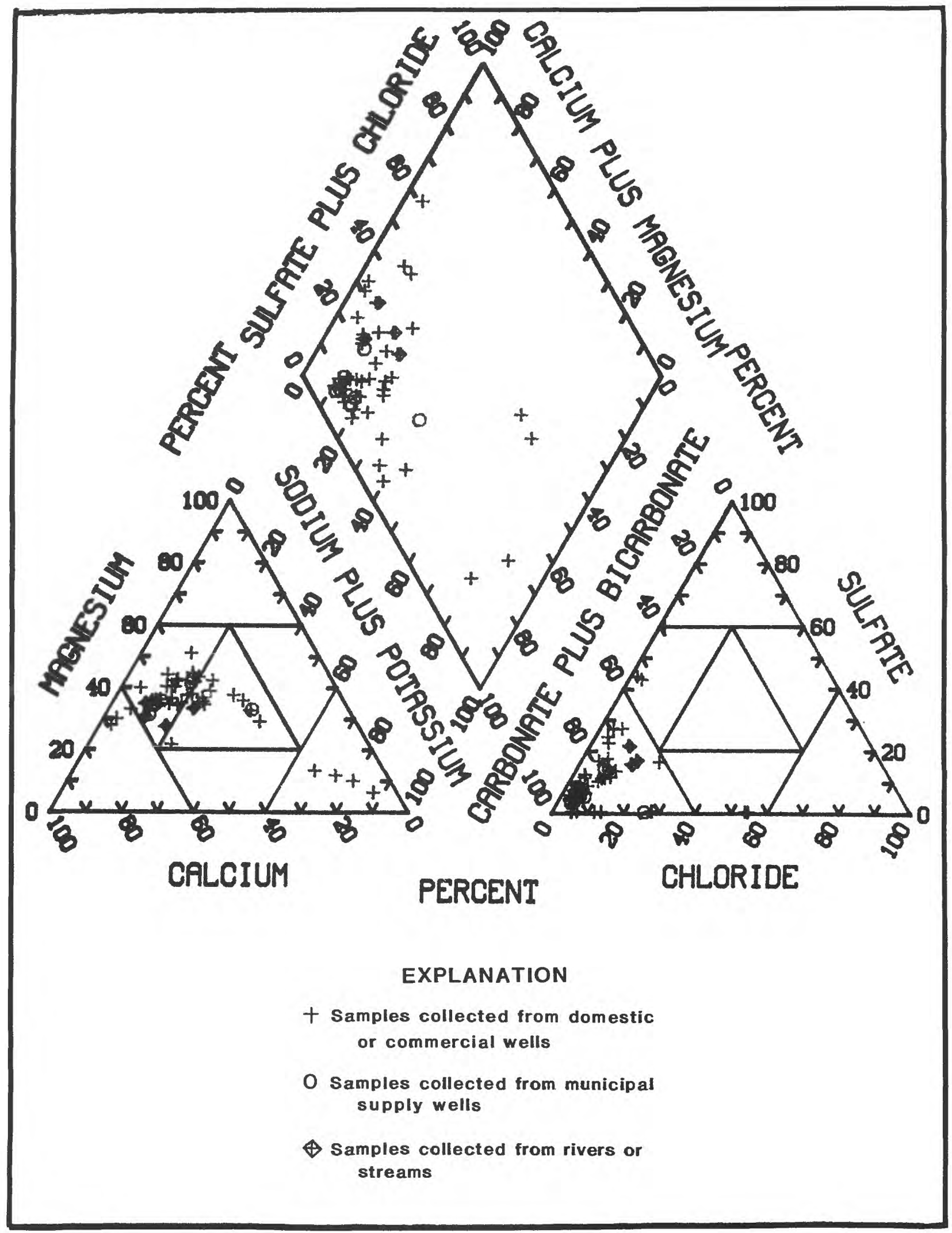

Figure 20.--Piper diagram showing general water-quality relations of ground water and surface water in Williams County, Ohio (all samples collected in 1985.) 
Table 7.-Water-quality statistics for ground water in Williams County, Ohio

[mg/L, milligrams per liter; $\mu \mathrm{g} / \mathrm{L}$, micrograms per liter; $\mu \mathrm{S} / \mathrm{cm}$, microsiemens per centimeter at 25 degrees Celsius. Statistics are based on at least 46 values for each property or constituent.]

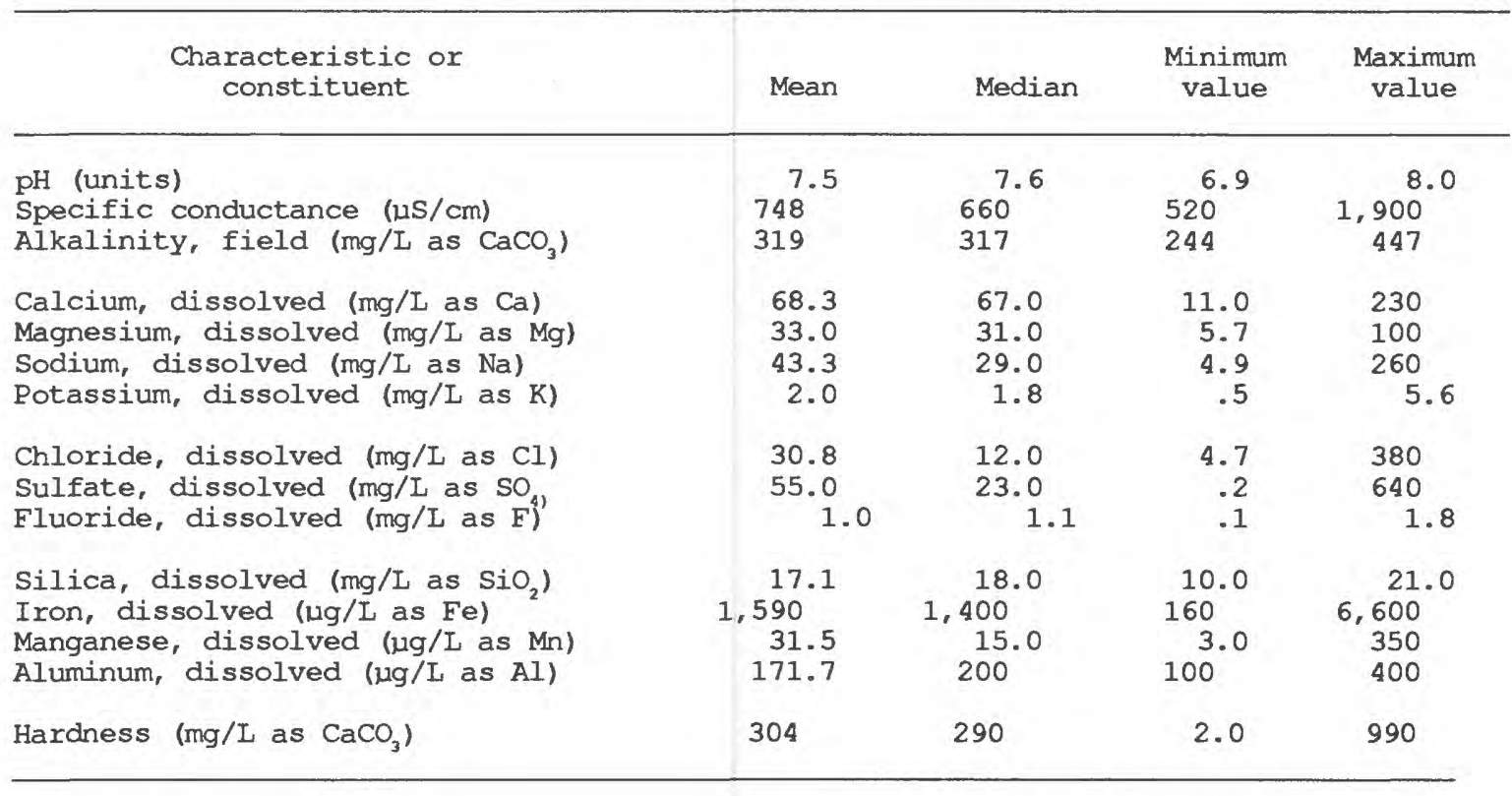

Hardness ( $a \mathrm{CaCO}_{3}$ ) had a median of $290 \mathrm{mg} / \mathrm{L}$; thus, the water is considered hard (Hem, 1970). When the hardness is above $150 \mathrm{mg} / \mathrm{L}$, water softeners often are installed on domestic wells.

Bicarbonate, the major anion, ranged in concentration from $297 \mathrm{mg} / \mathrm{L}$ to $544 \mathrm{mg} / \mathrm{L}$.

The concentration of iron in most of the wells sampled was above the Ohio Environmental Protection Agency standard of $300 \mu \mathrm{g} / \mathrm{L}$ (micrograms per liter). The median was $1,400 \mu \mathrm{g} / \mathrm{L}$. The median concentration of manganese was $15 \mu \mathrm{g} / \mathrm{L}$. Several samples, how0 ever, had manganese concentrations above the $50-\mu \mathrm{g} / \mathrm{L}$ standard.

The median $\mathrm{pH}$ of the water was 7.6. The median specific conductance was $660 \mu \mathrm{S} / \mathrm{cm}$ (microsiemens per centimeter at 25 degrees Celsius).

All samples were analyzed for hydrogen sulfide. Although other research has detected some hydrogen sulfide in samples from southern Williams County, none was detected during this study.

Some barium concentrations greater than the drinking-water standard of $1,000 \mu \mathrm{g} / \mathrm{L}$ have been reported in the County. Thus, samples from 16 sites were analyzed for dissolved barium. Concentrations ranged from less than 100 to $700 \mu \mathrm{g} / \mathrm{L}$ (table 6). Dissolved barium is not common in waters high in sulfate. Barium is found in some 
clays and feldspars common in glacial deposits and in some pyritic shales, including the shales under Williams County. It is also a byproduct of some chemical, glass, ceramic, and rubber industries and is used in drilling muds (Baggett, 1987). More than 20 abandoned gas wells drilled in the 1890's (some with wood casings) are located in southcentral Williams County, and neither the type of drilling mud used nor the method of plugging the wells is known (Ohio Geological Survey, written commun., 1897).

Four stream samples were collected to compare surface-water quality with groundwater quality. The Piper diagram in figure 20 shows the similarity between surface-water and ground-water composition in Williams County. This, along with the conceptual model of ground-water flow, indicates that ground-water discharge makes up a large proportion of streamflow during low-flow periods.

The concentrations of most constituents are, however, lower in the surface-water samples than in ground water. The small percentage of the surface water that is runoff appears to reduce the concentrations of alkalinity and iron in the surface water. The higher levels of potassium, phosphorus, and chloride in the streams may be the result of human activities such as waste discharges or agricultural runoff.

Samples from 10 wells and the 4 streams were analyzed for the organic chemicals and toxic metals listed in table 2. The wells are spread throughout the County and are representative of its various deposits. No concentrations above laboratory detection limits were found.

\section{Areal Differences}

The quality of ground water in glacial deposits can differ areally because of the different materials and methods of deposition of the sediments, and the sediment's difference in chemical and hydraulic properties. Although most all of the samples analyzed showed a similar type of water - predominantly a calcium magnesium bicarbonate typethere is some difference in the proportion and concentration of the individual constituents across the County.

A picture of the water quality in the form of Stiff diagrams for some of the wells and municipal water supplies is plotted on a map of the County in figure 21. Stiff diagrams show the concentrations of some of the cations and anions in a form that can be easily compared. This figure and the Piper diagram in figure 20 suggest both the uniformity of the ground-water system as a whole (except for the lacustrine deposits in the southeastern part of the County) and the individuality of the sand and gravel bodies. The tight grouping of most of the water samples on the Piper diagram agrees with the other evidence indicating that the unconsolidated sediments generally act as one aquifer. The differences seen in the Stiff diagrams and the few outlying points on the Piper diagram suggest 

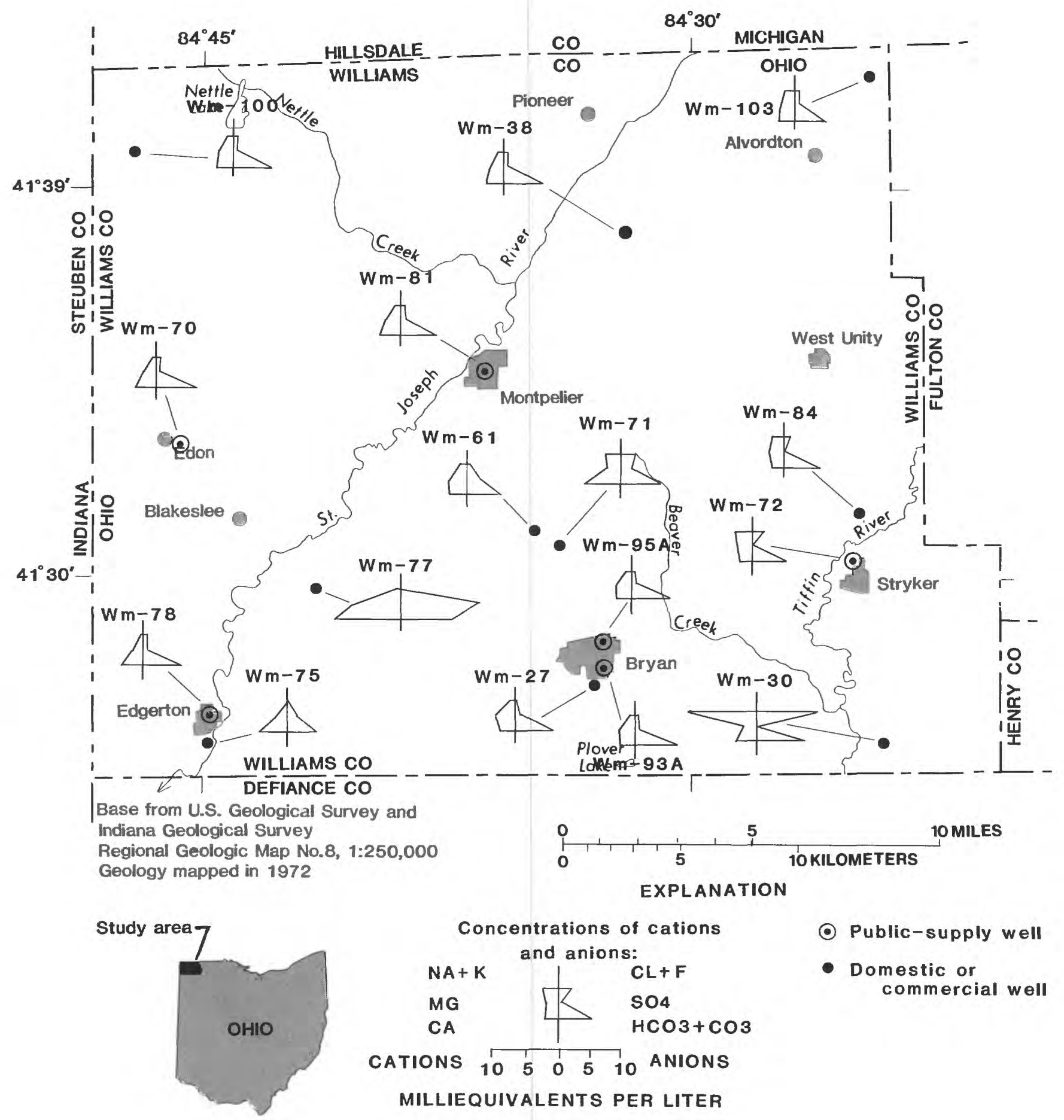

- Public-supply well

- Domestic or commercial well

Figure 21.--Stiff diagrams showing areal differences in water-quality in Williams County, Ohio. 


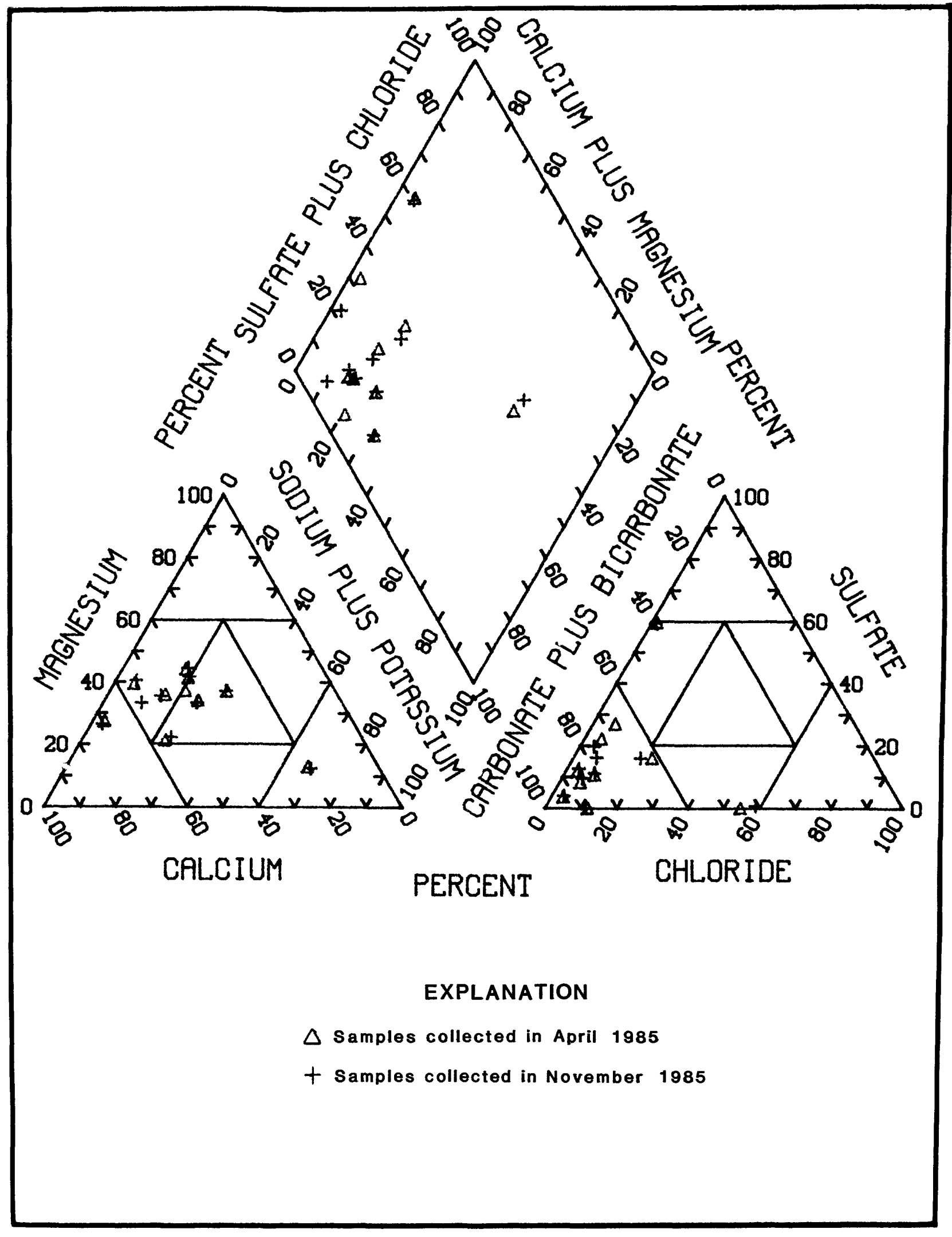

Figure 22.--Piper diagram showing seasonal variations in ground-water quality. 
that differences in the depth or composition of the sand and gravel bodies, their proximity to the shale below or to recharge areas, or the length of time that the ground water has been in the system may affect the quality of the water. The higher sodium content of the water in the southeastern corner of the County may be due to the composition of the lacustrine deposits in that part of the County.

\section{Seasonal Variations}

The Piper diagram in figure 22 compares the water quality of samples from 10 wells in April 1985 with samples from the same wells in November 1985. The April samples generally represent the yearly high in water levels, and the November sampling generally represents the annual low in water levels. The difference in water level was less than 10 $\mathrm{ft}$ at all wells measured. The chemical composition of the water was also similar between seasons. The lack of seasonal change in water level and water quality suggests that ground-water recharge and movement in the aquifer are quite slow.

\section{SUMMARY}

Williams County is flat to gently sloping and is mostly agricultural. The main topographic and geologic features are two northeast-southwest-trending end moraines. Almost half of the County's more than 36,000 residents live in the County's nine small towns. The County seat is Bryan.

Williams County is underlain by 60 to $320 \mathrm{ft}$ of unconsolidated sediments that are mostly of glacial origin. The sediments, which are thickest in the northwest and thin towards the southeast, can be categorized as unsorted tills containing end-moraine and ground-moraine deposits, outwash, and lacustrine and alluvial deposits. The unconsolidated sediments consist of gravel, sand, clay, and silt and contain many sand and gravel lenses. The sand and gravel bodies range from inches to tens of feet in thickness, but are discontinuous and cannot be correlated over long distances. A gravel and broken-rock zone at the bottom of the unconsolidated sediments, at the contact with the bedrock below, is present in many places.

Beneath the unconsolidated sediments are several hundred feet of Mississippian and Devonian rocks composed mostly of shale. The shales are not exposed at the surface in Williams County, and they yield little water. Beneath the shales is a thick column of older sedimentary rocks. The first formation that contains potable water is the Devonian Dundee Limestone.

Most ground water is withdrawn from the sand and gravel bodies in the unconsolidated sediments. Although these bodies are not all physically connected, the unconsoli- 
dated sediments appear to act as one aquifer on a regional scale. In most of the area the aquifer is semiconfined. Aquifer tests show that the silt or clay often covering or between the sand and gravel lenses is leaky. In areas where the sand and gravel is at or close to the surface, such as in parts of the end-moraine deposits or in other scattered areas, the aquifer is unconfined.

Hydraulic conductivities in the area are similar to the hydraulic conductivities reported in the literature for other unconsolidated sediments of glacial origin. Hydraulic conductivities range from 100 to $200 \mathrm{ft} / \mathrm{d}$ in the end- and ground-moraine deposits and are about an order of magnitude lower in the finer lacustrine sediments. These values are approximate, as the deposits are not homogeneous, and the sand and gravel bodies are not continuous. Vertical hydraulicconductivities may approach the horizontal hydraulic conductivities in the unsorted sand and gravel bodies, but are at least one or two orders of magnitude lower in the clays that cover much of the area.

Williams County is part of a larger, regional ground-water system. Water enters the system as precipitation. Of the 34 in. of annual precipitation that falls on the County on the average, about 2 to 8 in. eventually becomes ground water. The recharge area includes Williams County and parts of southern Michigan and northeastern Indiana. In Williams County, most of the recharge takes place on the two areas of end-moraine deposits.

Regional flow is toward the southeast, and the hydraulic gradient is about 10 to $30 \mathrm{ft} / \mathrm{mi}$. Locally, ground water flows toward streams. The principal means of discharge of water from the system is to the streams and rivers that drain the County. Water withdrawn by pumping is a small percentage of the total discharge.

From November 1984 through November 1986, water levels were usually less than $60 \mathrm{ft}$ below the surface throughout the County. Seasonally, water levels fluctuated an average $4 \mathrm{ft}$ or less. Highs occurred in late spring and lows occurred in late fall. Historically, water levels have generally reflected long-term climatic and cultural patterns, rising and falling slowly to keep the system in balance with long-term changes in precipitation, evapotranspiration, and increasingly, with changes in withdrawal demands.

Well yields for all but the southeastern corner of the County, where the lacustrine sediments are mostly more fine-grained and thinner, can be greater than $500 \mathrm{gal} / \mathrm{min}$. Yields adequate for domestic use are readily available, usually within $130 \mathrm{ft}$ of the surface. Yields of more than 1,000 gal/min are possible if a productive sand and gravel lens or the deeper gravel/broken-rock zone is tapped. In the extreme southeastern corner of the County, yields average $25 \mathrm{gal} / \mathrm{min}$.

All but the smallest streams appear to gain water from the aquifer below. This allows some streams, such as Beaver Creek, to sustain flows during dry periods. The 
headwaters of some streams appear to lose water to the unconsolidated sediments below as the streams cross the end moraines.

A mathematical simulation of ground-water flow in Williams County results in a potentiometric-surface map that approximates the actual measured water-level surface. The simulated water budget is close to the estimated water budget. The simulation also shows the ground-water system can support additional withdrawals. The effect of the additional stress on the system is controlled by the location, spacing, and discharge rate of the new wells. In other words, the amount of drawdown and the extent of the cone of depression depends on the size and location of the new well.

In terms of quality, ground water in Williams County generally is suitable for most uses. Water from 48 wells and 4 streams was analyzed. The ground water is mostly a calcium magnesium bicarbonate type. It is generally hard and contains elevated concentrations of iron. In the southeast, it also contains elevated concentrations of sodium. The proportions and concentrations of the constituents differ somewhat throughout the County, which reflects the differing geology and properties of the individual sand and gravel bodies. Seventeen samples analyzed for toxic metals and organic chemicals were free of detectable levels of these constituents. Seasonal variations in the water quality were very small.

The quality of the surface water was similar to that of ground water, though many constituents were less concentrated. Stream-water-quality data support other data that show most of the streamflow is ground water during times of low flow.

The unconsolidated sediments underlying Williams County contain adequate water of suitable quality for use by an expanding population.

\section{SELECTED REFERENCES}

Baggett, S. M., 1987, Ground-water resources of the Bryan area, Williams County, Ohio: Toledo, Ohio, Unpublished Master's Thesis, The University of Toledo, Department of Geology, 145 p.

Bryan Municipal Utilities, 1985a, Annual report for 1984, Bryan, Ohio: $36 \mathrm{p}$.

_ 1985b, Monthly pumping data: Bryan, Ohio: File Report.

- 1986, Annual report for 1985, Bryan, Ohio: $49 \mathrm{p}$.

Burgess and Niple, Ltd., 1967, Northwest Ohio water development plan: Ohio Department of Natural Resources, 299 p. 
Federal Interagency Work Groups, 1977, National handbook of recommended methods for water-data acquisition: U.S. Geological Survey, Office of Water Data Coordination, Reston, Virginia.

Fetter, C. W., Jr., 1980, Applied hydrogeology: Columbus, Ohio, Charles E. Merrill $488 \mathrm{p}$.

Freeze, A. R., and Cherry, J. A., 1979, Groundwater: Englewood Cliffs, New Jersey, Prentice-Hall, $604 \mathrm{p}$.

Goldthwait, R. P, 1959, Scenes in Ohio during the last Ice Age: Ohio Journal of Science, v. 59 , no. 4 , p. 193-216.

Hantush, M. S., 1960, Modification of the theory of leaky aquifers: Journal of Geophysical Research, v. 65, no. 11, p. 3713-3725.

Harlement, P. A., and Heck, H. E., 1968, Bryan, Ohio water-resources report: Toledo, Ohio, Jones and Henry, Ltd., 13 p.

Heath, R. C., 1983, Basic ground-water hydrology: U.S. Geological Survey Water Supply Paper 2220, 85 p.

Hem, J. D., 1970, The study and interpretation of the chemical characteristics of water: U.S. Geological Survey Water Supply Paper 1473, 363 p.

Hough, J. L., 1958, Geology of the Great Lakes: Urbana, Illinois, University of Illinois Press, 313 p.

Johnson, D. P., and Metzker, K. D., 1981, Low flow characteristics of Ohio streams: U.S. Geological Survey Open-File Report 81-1195, 285 p.

Johnson, G. H., and Keller, S. J., 1972, Geologic map of the 1' x 2' Fort Wayne Quadrangle, Indiana, Michigan and Ohio, showing bedrock and unconsolidated deposits: Bloomington, Indiana, Indiana Department of Natural Resources, Regional Geologic Map 8.

King, J. M., 1977, Ground-water resources of Williams County, Ohio: Toledo, Ohio, Unpublished Master's Thesis, The University of Toledo, Department of Geology, $114 \mathrm{p}$.

King, J. M., and Ruedisili, L. C, 1981, The effects of municipal pumping from a shallow glacial aquifer at Bryan, northwestern Ohio: Ohio Journal of Science, v. 82, no. 2, p. 55-63. 
Lohman, S. W., 1972, Ground-water hydraulics: U.S. Geological Survey Professional Paper 708, $70 \mathrm{p}$.

McDonald, M. G., and Harbaugh, A. W., 1984, A modular three-dimensional finitedifference ground-water flow model: U.S. Geological Survey Water-Resources Investigations Report 83-875, 528 p.

Norris, S. E, 1963, Permeability of glacial till: U.S. Geological Survey Professional Paper 450-E, Article 224, p. E150-E151.

Ohio Department of Natural Resources, Division of Lands and Soil, 1975, An inventory of Ohio soils, Williams County: Columbus, Ohio, Progress Report 44, 71 p.

Ohio Department of Natural Resources, Division of Water, 1959, Tiffin River basin, underground resources: Columbus, Ohio, Ohio Water Plan Inventory, File Index Map A-8.

_ 1960, Water inventory of the Maumee River basin: Columbus, Ohio, Ohio Water Plan Inventory Report 11, $112 \mathrm{p}$.

_ 1962, Hydrologic atlas: Columbus, Ohio, Ohio Water Plan Inventory Report 13, 4 plates.

_ـ 1969a, Well Number M-44, Williams County: Columbus, Ohio, Report 43. 1969b, Well Number M-43, Williams County: Columbus, Ohio, Report 49.

- 1970, Ground-water planning in northwest Ohio: A study of the carbonate rock aquifers: Columbus, Ohio, Ohio Water Plan Inventory Report 22, 63 p..

Ohio Drilling Company, 1985, Report concerning the test pumping of municipal wells nos. 1 through 5: Massillon, Ohio, $17 \mathrm{p}$.

Ohio Environmental Protection Agency, 1985, Williams County Landfill: Open-File Report.

Orton, E., 1898, The rock waters of Ohio: U.S. Geological Survey 19th Annual Report, Part 4B, p. 633-717.

Pettyjohn, W. A., and Henning, R. J., 1977, Regional ground-water recharge rates in Ohio: Geological Society of America Abstracts with Programs, 11th Annual Meeting, North-Central Section, v. 9, no. 5, p. 641. 
Piper, A. M., 1944, A graphic procedure in the geochemical interpretation of water analyses: American Geophysical Union Transactions, v. 25, p. 914-923.

Soil Testing and Engineering, Inc., 1979, Williams County Landfill soil test report: Fort Wayne, Indiana, $5 \mathrm{p}$.

Stout, W., Ver Steeg, K., and Lamb, G. F., 1943, Geology of water in Ohio: Columbus, Ohio, Ohio Department of Natural Resources, Division of Geological Survey, Fourth Series, Bulletin 44, 694 p.

Theis, C. V., 1935, The relation between the lowering of the piezometric surface and the rate and duration of discharge of a well using ground-water storage: American Geophysical Union Transactions, part 2, p. 519-524.

Todd, D. K., 1980, Groundwater Hydrology: New York, Wiley, 535 p.

U.S. Bureau of the Census, 1981, Advance reports, 1980 census of population and housing, Ohio: $43 \mathrm{p}$.

U.S. Department of Agriculture, Soil Conservation Service, 1978, Soil Survey of Williams County, Ohio: Columbus, Ohio, 139 p.

U.S. Environmental Protection Agency, 1982a, Maximum contaminant levels (subpart B of part 141, National interim primary drinking water regulations): U.S. Code of Federal Regulations, Title 40, Parts 100 to 140, p. 315-318.

— 1982b, Secondary maximum contaminant levels (section 143.3 of part 143, National secondary drinking water regulations): U.S. Code of Federal Regulations, Title 40, Parts 100 to 149 , p. 374.

Walton, W. C., 1970, Groundwater resource evaluation: New York, McGraw-Hill, $664 \mathrm{p}$.

Wastewater Treatment Plant, City of Bryan, 1985, Monthly precipitation data for the Bryan Wastewater Treatment Plant: Bryan, Ohio, Open-File Report. 
Table 1.--Well information and water levels from selected wells in Williams County, Ohio [--, data not available]

\begin{tabular}{|c|c|c|c|c|c|c|}
\hline $\begin{array}{l}\text { Local } \\
\text { well } \\
\text { number }\end{array}$ & Site number & Owner & $\begin{array}{l}\text { Depth } \\
\text { of well } \\
(\text { feet })^{1}\end{array}$ & $\begin{array}{c}\text { Altitude } \\
\text { (feet above } \\
\text { sea level) }\end{array}$ & Date & $\begin{array}{l}\text { Water } \\
\text { level } \\
\text { (feet) }\end{array}$ \\
\hline WM-1-D14 & 412821084323600 & $\begin{array}{l}\text { Ohio Dept. } \\
\text { of Natural } \\
\text { Resources }\end{array}$ & 118 & 747 & $\begin{array}{l}01 / 09 / 85 \\
04 / 25 / 85 \\
07 / 11 / 85 \\
11 / 05 / 85 \\
05 / 14 / 86 \\
11 / 14 / 86\end{array}$ & $\begin{array}{l}20.00 \\
23.30 \\
27.30 \\
28.20 \\
30.10 \\
28.40\end{array}$ \\
\hline WM-2-B5 & 412711084424400 & do. & 119 & 835 & $\begin{array}{l}04 / 15 / 85 \\
07 / 10 / 85 \\
09 / 09 / 85 \\
11 / 05 / 85 \\
05 / 13 / 86 \\
11 / 13 / 86\end{array}$ & $\begin{array}{l}36.27 \\
38.81 \\
37.43 \\
39.65 \\
38.67 \\
39.40\end{array}$ \\
\hline WM-20-D14 & 412842084321300 & $\begin{array}{r}\text { City of } \\
\text { Bryan }\end{array}$ & -- & 748 & $\begin{array}{l}11 / 05 / 84 \\
04 / 23 / 85 \\
07 / 09 / 85 \\
11 / 06 / 85 \\
05 / 13 / 86 \\
11 / 13 / 86\end{array}$ & $\begin{array}{l}28.83 \\
24.20 \\
27.30 \\
26.80 \\
25.50 \\
23.70\end{array}$ \\
\hline WM-21-E15 & 412930084320900 & do. & 174 & 770 & $\begin{array}{l}11 / 05 / 84 \\
01 / 09 / 85 \\
04 / 24 / 85 \\
07 / 09 / 85 \\
11 / 06 / 85 \\
05 / 13 / 86 \\
11 / 13 / 86\end{array}$ & $\begin{array}{l}20.60 \\
17.02 \\
16.05 \\
21.20 \\
20.60 \\
18.60 \\
19.00\end{array}$ \\
\hline WM-22-E16 & 412929084304900 & do. & 133 & 720 & $\begin{array}{l}01 / 09 / 85 \\
04 / 24 / 85 \\
06 / 28 / 85 \\
07 / 09 / 85 \\
11 / 05 / 85 \\
11 / 06 / 85 \\
05 / 14 / 86 \\
11 / 12 / 86\end{array}$ & $\begin{array}{l}-3.00 \\
-2.95 \\
-3.00 \\
-3.00 \\
-1.96 \\
-3.00 \\
-3.00 \\
-3.00\end{array}$ \\
\hline$W M-23-C 15$ & 412742084313600 & do. & -- & 730 & $\begin{array}{l}11 / 05 / 84 \\
01 / 09 / 85 \\
04 / 02 / 85 \\
07 / 09 / 85 \\
11 / 04 / 85 \\
05 / 13 / 86 \\
11 / 13 / 86\end{array}$ & $\begin{array}{l}3.45 \\
1.05 \\
2.32 \\
4.42 \\
5.50 \\
5.15 \\
4.70\end{array}$ \\
\hline
\end{tabular}


Table 1.--Well information and water levels from selected wells in Williams County, Ohio--Continued

\begin{tabular}{|c|c|c|c|c|c|c|}
\hline $\begin{array}{l}\text { Local } \\
\text { well } \\
\text { number }\end{array}$ & Site number & Owner & $\begin{array}{l}\text { Depth } \\
\text { of well } \\
(\text { feet })^{1}\end{array}$ & $\begin{array}{c}\text { Altitude } \\
\text { (feet above } \\
\text { sea level) }\end{array}$ & Date & $\begin{array}{l}\text { Water } \\
\text { level } \\
\text { (feet) }^{1}\end{array}$ \\
\hline WM-24-B15 & 412632084312500 & A. Rupp & 108 & 730 & $\begin{array}{l}11 / 06 / 84 \\
01 / 09 / 85 \\
04 / 22 / 85 \\
07 / 11 / 85 \\
11 / 05 / 85 \\
05 / 14 / 86 \\
11 / 14 / 86\end{array}$ & $\begin{array}{l}4.23 \\
3.52 \\
3.50 \\
4.40 \\
7.40 \\
4.10 \\
5.80\end{array}$ \\
\hline WM-25-D18 & 412820084274600 & J. Livengood & -- & 720 & $\begin{array}{l}11 / 06 / 84 \\
01 / 09 / 85 \\
04 / 15 / 85 \\
07 / 11 / 85 \\
11 / 06 / 85 \\
05 / 14 / 86 \\
11 / 14 / 86\end{array}$ & $\begin{array}{l}16.09 \\
18.79 \\
15.30 \\
16.30 \\
16.70 \\
16.10 \\
16.60\end{array}$ \\
\hline WM-26-C17 & 412729084295000 & N. Martin & 104 & 720 & $\begin{array}{l}11 / 06 / 84 \\
01 / 09 / 85 \\
04 / 15 / 85 \\
07 / 11 / 85 \\
11 / 07 / 85 \\
05 / 14 / 86 \\
11 / 14 / 86\end{array}$ & $\begin{array}{l}11.35 \\
10.84 \\
10.12 \\
11.42 \\
11.80 \\
10.90 \\
11.60\end{array}$ \\
\hline WM-27-C14 & 412723084325300 & N. McBride & 138 & 740 & $\begin{array}{l}11 / 06 / 84 \\
01 / 09 / 85 \\
04 / 23 / 85 \\
07 / 11 / 85 \\
11 / 07 / 85 \\
05 / 14 / 86 \\
11 / 12 / 86\end{array}$ & $\begin{array}{l}7.62 \\
5.39 \\
7.08 \\
9.25 \\
8.70 \\
8.90 \\
9.40\end{array}$ \\
\hline WM-28-013 & 412906084341800 & R. Rataiczak & 123 & 795 & $\begin{array}{l}11 / 06 / 84 \\
01 / 08 / 85 \\
04 / 24 / 85 \\
07 / 10 / 85 \\
11 / 06 / 85 \\
05 / 13 / 86 \\
11 / 12 / 86\end{array}$ & $\begin{array}{l}24.08 \\
21.65 \\
22.40 \\
19.60 \\
24.18 \\
27.20 \\
28.60\end{array}$ \\
\hline WM-29-E15 & 412913084313800 & w. Timerman & 71 & 745 & $\begin{array}{l}11 / 06 / 84 \\
01 / 09 / 85 \\
04 / 15 / 85 \\
07 / 10 / 85 \\
11 / 06 / 85 \\
05 / 14 / 86 \\
11 / 12 / 86\end{array}$ & $\begin{array}{l}20.13 \\
13.50 \\
13.81 \\
22.30 \\
20.50 \\
17.00 \\
15.70\end{array}$ \\
\hline
\end{tabular}


Table 1.--Well information and water levels from selected wells in Williams County, Ohio--Continued

\begin{tabular}{|c|c|c|c|c|c|c|}
\hline $\begin{array}{l}\text { Local } \\
\text { well } \\
\text { number }\end{array}$ & Site number & Owner & $\begin{array}{l}\text { Depth } \\
\text { of well } \\
(\text { feet })^{1}\end{array}$ & $\begin{array}{c}\text { Altitude } \\
\text { (feet above } \\
\text { sea level) }\end{array}$ & Date & $\begin{array}{l}\text { Water } \\
\text { level } \\
\text { (feet) }^{1}\end{array}$ \\
\hline $\mathrm{WM}-30-\mathrm{B} 21$ & 412630084241500 & B. Woolace & 100 & 710 & $\begin{array}{l}11 / 06 / 84 \\
01 / 09 / 85 \\
04 / 15 / 85 \\
07 / 11 / 85 \\
11 / 07 / 85 \\
05 / 14 / 86 \\
11 / 14 / 86\end{array}$ & $\begin{array}{l}27.95 \\
28.16 \\
27.38 \\
28.08 \\
28.00 \\
27.00 \\
28.90\end{array}$ \\
\hline WM-31-E23 & 412935084222300 & W. Nafziger & 128 & 715 & $\begin{array}{l}11 / 06 / 84 \\
01 / 07 / 85 \\
04 / 24 / 85 \\
07 / 08 / 85 \\
11 / 06 / 85\end{array}$ & $\begin{array}{l}31.62 \\
31.12 \\
31.20 \\
31.40 \\
31.15\end{array}$ \\
\hline WM-32-D21 & 412840084244300 & R. Coy & 95 & 720 & $\begin{array}{l}11 / 06 / 84 \\
01 / 07 / 85 \\
04 / 19 / 85 \\
07 / 08 / 85 \\
11 / 06 / 85 \\
05 / 12 / 86 \\
11 / 12 / 86\end{array}$ & $\begin{array}{l}18.45 \\
17.20 \\
17.52 \\
18.22 \\
18.05 \\
16.00 \\
18.00\end{array}$ \\
\hline WM-33-D15 & 412840084310800 & F. Meek & 117 & 740 & $\begin{array}{l}11 / 06 / 84 \\
01 / 09 / 85 \\
04 / 15 / 85 \\
07 / 11 / 85 \\
11 / 07 / 85 \\
05 / 14 / 86 \\
11 / 12 / 86\end{array}$ & $\begin{array}{l}18.60 \\
17.30 \\
18.65 \\
22.89 \\
25.95 \\
23.10 \\
22.20\end{array}$ \\
\hline WM-34-C14 & 412740084320700 & G. Vincent & 115 & 735 & $\begin{array}{l}11 / 06 / 84 \\
01 / 09 / 85 \\
04 / 24 / 85 \\
07 / 11 / 85 \\
11 / 07 / 85 \\
05 / 14 / 86 \\
11 / 12 / 86\end{array}$ & $\begin{array}{l}5.10 \\
2.35 \\
4.10 \\
6.40 \\
6.00 \\
6.40 \\
6.10\end{array}$ \\
\hline WM-35-D12 & 412842084352800 & R. Hetz & 91 & 790 & $\begin{array}{l}11 / 06 / 84 \\
01 / 09 / 85 \\
04 / 23 / 85 \\
07 / 10 / 85 \\
11 / 06 / 85 \\
05 / 13 / 86 \\
11 / 12 / 86\end{array}$ & $\begin{array}{l}17.22 \\
15.78 \\
13.30 \\
17.66 \\
17.50 \\
15.40 \\
16.50\end{array}$ \\
\hline $\mathrm{WM}-36-\mathrm{B} 10$ & 412629084371600 & S. Davis & -- & 815 & $\begin{array}{l}11 / 07 / 84 \\
01 / 09 / 85 \\
04 / 24 / 85 \\
07 / 10 / 85 \\
11 / 05 / 85 \\
05 / 13 / 86 \\
11 / 13 / 86\end{array}$ & $\begin{array}{l}24.92 \\
23.93 \\
23.30 \\
24.75 \\
25.10 \\
22.60 \\
24.70\end{array}$ \\
\hline
\end{tabular}


Table 1.--Well information and water levels from selected wells in williams County, Ohio--Continued

\begin{tabular}{|c|c|c|c|c|c|c|}
\hline $\begin{array}{l}\text { Local } \\
\text { well } \\
\text { number }\end{array}$ & Site number & Owner & $\begin{array}{l}\text { Depth } \\
\text { of well } \\
(\text { feet })^{1}\end{array}$ & $\begin{array}{c}\text { Altitude } \\
\text { (feet above } \\
\text { sea level) }\end{array}$ & Date & $\begin{array}{l}\text { Water } \\
\text { level } \\
\text { (feet) }{ }^{1}\end{array}$ \\
\hline WM-37-D9 & 412814084384300 & A. Stuble & -- & 840 & $\begin{array}{l}11 / 07 / 84 \\
01 / 09 / 85 \\
04 / 16 / 85 \\
07 / 10 / 85 \\
11 / 06 / 85 \\
05 / 13 / 86 \\
11 / 12 / 86\end{array}$ & $\begin{array}{l}40.50 \\
40.38 \\
39.48 \\
40.02 \\
39.10 \\
42.60 \\
39.90\end{array}$ \\
\hline WM-38-115 & 413240084311400 & R. Opdycke & 43 & 795 & $\begin{array}{l}11 / 07 / 84 \\
01 / 07 / 85 \\
04 / 24 / 85 \\
07 / 08 / 85 \\
11 / 06 / 85 \\
05 / 14 / 86 \\
11 / 12 / 86\end{array}$ & $\begin{array}{l}17.02 \\
16.08 \\
16.37 \\
17.40 \\
17.25 \\
16.70 \\
17.00\end{array}$ \\
\hline WM-39-H17 & 413208084291300 & W. Oberlin & 144 & 765 & $\begin{array}{l}11 / 07 / 84 \\
01 / 07 / 85 \\
04 / 22 / 85 \\
07 / 08 / 85 \\
11 / 06 / 85 \\
05 / 14 / 86 \\
11 / 12 / 86\end{array}$ & $\begin{array}{r}9.55 \\
8.65 \\
9.09 \\
10.70 \\
10.10 \\
9.30 \\
9.60\end{array}$ \\
\hline WM-40-J16 & 413417084302600 & R. Miller & 69 & 815 & $\begin{array}{l}11 / 07 / 84 \\
01 / 07 / 85 \\
04 / 22 / 85 \\
07 / 08 / 85 \\
11 / 06 / 85 \\
05 / 14 / 86 \\
11 / 12 / 86\end{array}$ & $\begin{array}{l}26.52 \\
25.28 \\
25.40 \\
23.45 \\
26.85 \\
25.60 \\
28.90\end{array}$ \\
\hline WM-41-M17 & 413604084290100 & D. Borton & -- & 830 & $\begin{array}{l}11 / 07 / 84 \\
01 / 07 / 85 \\
04 / 24 / 85 \\
07 / 08 / 85 \\
11 / 06 / 85 \\
05 / 12 / 86 \\
11 / 12 / 86\end{array}$ & $\begin{array}{l}21.95 \\
20.68 \\
20.42 \\
22.08 \\
22.30 \\
21.20 \\
21.60\end{array}$ \\
\hline WM-42-613 & 413541084331700 & J. Seto & 84 & 890 & $\begin{array}{l}11 / 07 / 84 \\
01 / 07 / 85 \\
04 / 24 / 85 \\
07 / 09 / 85 \\
11 / 06 / 85 \\
05 / 14 / 86 \\
11 / 13 / 86\end{array}$ & $\begin{array}{l}59.75 \\
57.38 \\
57.40 \\
59.75 \\
58.80 \\
58.40 \\
58.00\end{array}$ \\
\hline
\end{tabular}


Table 1.--Well information and water levels from selected wells in Williams County, Ohio--Continued

\begin{tabular}{|c|c|c|c|c|c|c|}
\hline $\begin{array}{l}\text { Local } \\
\text { well } \\
\text { number }\end{array}$ & Site number & Owner & $\begin{array}{l}\text { Depth } \\
\text { of well } \\
(\text { feet })^{1}\end{array}$ & $\begin{array}{l}\text { Altitude } \\
\text { (feet above } \\
\text { sea level) }\end{array}$ & Date & $\begin{array}{l}\text { Water } \\
\text { level } \\
\text { (feet) }\end{array}$ \\
\hline WM-43-J14 & 413418084330300 & J. Niday & 94 & 875 & $\begin{array}{l}11 / 07 / 84 \\
01 / 07 / 85 \\
04 / 24 / 85 \\
07 / 09 / 85 \\
11 / 06 / 85 \\
05 / 14 / 86 \\
11 / 13 / 86\end{array}$ & $\begin{array}{l}64.33 \\
62.22 \\
61.85 \\
64.16 \\
64.39 \\
64.00 \\
63.70\end{array}$ \\
\hline$W M-44-E 8$ & 412958084394700 & M. Smith & 143 & 880 & $\begin{array}{l}11 / 07 / 84 \\
01 / 08 / 85 \\
04 / 24 / 85 \\
07 / 10 / 85 \\
11 / 05 / 85 \\
05 / 13 / 86 \\
11 / 13 / 86\end{array}$ & $\begin{array}{l}71.39 \\
70.70 \\
69.60 \\
70.53 \\
71.26 \\
70.00 \\
71.20\end{array}$ \\
\hline$W M-45-B 8$ & 412720084400700 & G. McCool & 89 & 860 & $\begin{array}{l}11 / 07 / 84 \\
01 / 09 / 85 \\
04 / 24 / 85 \\
07 / 10 / 85 \\
11 / 05 / 85 \\
05 / 13 / 86 \\
11 / 13 / 86\end{array}$ & $\begin{array}{l}59.34 \\
58.48 \\
57.10 \\
58.70 \\
59.40 \\
58.20 \\
62.30\end{array}$ \\
\hline WM-46-E11 & 412912084361400 & R. Pickering & 74 & 820 & $\begin{array}{l}11 / 07 / 84 \\
01 / 08 / 85 \\
04 / 24 / 85 \\
07 / 10 / 85 \\
11 / 06 / 85 \\
05 / 13 / 86 \\
11 / 12 / 86\end{array}$ & $\begin{array}{l}33.30 \\
32.18 \\
31.55 \\
33.40 \\
33.50 \\
33.90 \\
32.40\end{array}$ \\
\hline WM-47-E12 & 412957084342900 & G. Martin & 120 & 815 & $\begin{array}{l}11 / 07 / 84 \\
01 / 08 / 85 \\
04 / 24 / 85 \\
07 / 11 / 85 \\
11 / 06 / 85 \\
05 / 14 / 86 \\
11 / 12 / 86\end{array}$ & $\begin{array}{l}27.63 \\
26.18 \\
25.89 \\
27.86 \\
28.00 \\
26.60 \\
26.90\end{array}$ \\
\hline WM-48-D12 & 412820084342500 & T. Ringer & 146 & 790 & $\begin{array}{l}11 / 08 / 84 \\
01 / 08 / 85 \\
04 / 24 / 85 \\
07 / 10 / 85 \\
11 / 07 / 85 \\
05 / 13 / 86 \\
11 / 13 / 86\end{array}$ & $\begin{array}{l}45.69 \\
37.18 \\
33.70 \\
36.18 \\
37.35 \\
34.10 \\
33.80\end{array}$ \\
\hline
\end{tabular}


Table 1.--Well information and water levels from selected wells in williams County, Ohio--Continued

\begin{tabular}{|c|c|c|c|c|c|c|}
\hline $\begin{array}{l}\text { Local } \\
\text { well } \\
\text { number }\end{array}$ & Site number & Owner & $\begin{array}{l}\text { Depth } \\
\text { of well } \\
(\text { feet })^{1}\end{array}$ & $\begin{array}{c}\text { Altitude } \\
\text { (feet above } \\
\text { sea level) }\end{array}$ & Date & $\begin{array}{l}\text { Water } \\
\text { level } \\
\text { (feet) }^{1}\end{array}$ \\
\hline$W M-49-G 20$ & 413055084255800 & D. Clemens & 120 & 720 & $\begin{array}{l}11 / 08 / 84 \\
01 / 07 / 85 \\
04 / 18 / 85 \\
07 / 08 / 85 \\
11 / 06 / 85 \\
05 / 12 / 86 \\
11 / 12 / 86\end{array}$ & $\begin{array}{l}13.37 \\
11.93 \\
12.68 \\
13.45 \\
14.10 \\
11.75 \\
12.50\end{array}$ \\
\hline WM-50-E19 & 412952084262100 & R. Rosebrook & 92 & 715 & $\begin{array}{l}11 / 08 / 84 \\
01 / 07 / 85 \\
04 / 18 / 85 \\
07 / 08 / 85 \\
11 / 06 / 85 \\
05 / 12 / 86 \\
11 / 12 / 86\end{array}$ & $\begin{array}{r}11.70 \\
9.90 \\
9.90 \\
12.30 \\
11.40 \\
8.80 \\
10.90\end{array}$ \\
\hline WM-51-B20 & 412722084261000 & $\begin{array}{l}\text { Oak Grove } \\
\text { Church }\end{array}$ & 103 & 710 & $\begin{array}{l}11 / 08 / 84 \\
01 / 09 / 85 \\
04 / 15 / 85 \\
07 / 11 / 85 \\
11 / 07 / 85 \\
05 / 14 / 86 \\
11 / 14 / 86\end{array}$ & $\begin{array}{l}10.80 \\
10.55 \\
10.05 \\
10.60 \\
10.80 \\
10.40 \\
10.20\end{array}$ \\
\hline WM- 52-B24 & 412719084211000 & M. Niese & 98 & 715 & $\begin{array}{l}11 / 08 / 84 \\
01 / 07 / 85 \\
04 / 15 / 85 \\
07 / 08 / 85 \\
11 / 07 / 85 \\
05 / 12 / 86 \\
11 / 12 / 86\end{array}$ & $\begin{array}{l}35.27 \\
34.93 \\
34.82 \\
35.00 \\
35.06 \\
35.30 \\
35.80\end{array}$ \\
\hline WM-53-H11 & 413233084353700 & $\begin{array}{l}\text { Bethesda } \\
\text { Church }\end{array}$ & -- & 870 & $\begin{array}{l}11 / 13 / 84 \\
01 / 08 / 85 \\
04 / 24 / 85 \\
07 / 09 / 85 \\
11 / 06 / 85 \\
05 / 14 / 86 \\
11 / 13 / 86\end{array}$ & $\begin{array}{l}58.30 \\
79.90 \\
55.70 \\
57.95 \\
58.42 \\
53.90 \\
57.70\end{array}$ \\
\hline WM-54-L12 & 413557084342200 & V. Boardner & 84 & 880 & $\begin{array}{l}11 / 13 / 84 \\
01 / 08 / 85 \\
04 / 22 / 85 \\
07 / 10 / 85 \\
11 / 06 / 85\end{array}$ & $\begin{array}{l}41.20 \\
39.40 \\
40.18 \\
42.63 \\
42.60\end{array}$ \\
\hline WM-55-L10 & 413512084371800 & R. Whetro & 45 & 860 & $\begin{array}{l}11 / 13 / 84 \\
01 / 08 / 85 \\
04 / 24 / 85 \\
07 / 09 / 85 \\
11 / 05 / 85 \\
05 / 13 / 86 \\
11 / 13 / 86\end{array}$ & $\begin{array}{l}17.98 \\
16.87 \\
18.90 \\
21.22 \\
21.11 \\
20.40 \\
20.80\end{array}$ \\
\hline
\end{tabular}


Table 1.--Well information and water levels from selected wells in williams County, Ohio--Continued

\begin{tabular}{|c|c|c|c|c|c|c|}
\hline $\begin{array}{l}\text { Local } \\
\text { well } \\
\text { number }\end{array}$ & Site number & Owner & $\begin{array}{l}\text { Depth } \\
\text { of well } \\
(\text { feet })^{1}\end{array}$ & $\begin{array}{c}\text { Altitude } \\
\text { (feet above } \\
\text { sea level) }\end{array}$ & Date & $\begin{array}{l}\text { Water } \\
\text { level } \\
\text { (feet) }^{1}\end{array}$ \\
\hline WM-56-L7 & 413556084401600 & D. Gulick & 60 & 890 & $\begin{array}{l}11 / 13 / 84 \\
01 / 08 / 85 \\
04 / 23 / 85 \\
07 / 09 / 85 \\
11 / 05 / 85 \\
05 / 13 / 86 \\
11 / 13 / 86\end{array}$ & $\begin{array}{l}18.39 \\
17.20 \\
17.00 \\
18.45 \\
18.61 \\
17.80 \\
18.20\end{array}$ \\
\hline WM-57-J9 & 413417084381400 & L. Zigler & 62 & 850 & $\begin{array}{l}11 / 13 / 84 \\
01 / 08 / 85 \\
04 / 23 / 85 \\
07 / 09 / 85 \\
11 / 05 / 85 \\
05 / 13 / 86 \\
11 / 13 / 86\end{array}$ & $\begin{array}{r}11.20 \\
9.98 \\
11.30 \\
15.40 \\
13.40 \\
13.00 \\
10.00\end{array}$ \\
\hline WM-58-J12 & 413403084342100 & P. Ruble & 215 & 870 & $\begin{array}{l}11 / 13 / 84 \\
01 / 08 / 85 \\
04 / 24 / 85 \\
07 / 10 / 85 \\
11 / 06 / 85 \\
05 / 14 / 86 \\
11 / 13 / 86\end{array}$ & $\begin{array}{l}46.40 \\
42.40 \\
42.20 \\
43.00 \\
45.00 \\
43.80 \\
43.60\end{array}$ \\
\hline WM-59-G12 & 413122084342300 & R. Rigg & 85 & 820 & $\begin{array}{l}11 / 13 / 84 \\
01 / 08 / 85 \\
04 / 24 / 85 \\
07 / 10 / 85 \\
11 / 06 / 85 \\
05 / 14 / 86 \\
11 / 13 / 86\end{array}$ & $\begin{array}{l}33.16 \\
31.73 \\
30.70 \\
33.00 \\
33.60 \\
31.60 \\
32.80\end{array}$ \\
\hline WM- 60-F12 & 413056084344700 & Smith-Hurley & -- & 830 & $\begin{array}{l}11 / 14 / 84 \\
01 / 08 / 85 \\
04 / 24 / 85 \\
07 / 10 / 85 \\
08 / 13 / 85 \\
05 / 14 / 86 \\
11 / 06 / 86 \\
11 / 13 / 86\end{array}$ & $\begin{array}{l}41.70 \\
37.70 \\
40.28 \\
41.67 \\
42.35 \\
40.50 \\
42.20 \\
41.40\end{array}$ \\
\hline WM- $61-G 12$ & 413056084350400 & $\begin{array}{l}\text { Williams Co. } \\
\text { Landfill }\end{array}$ & -- & 840 & $\begin{array}{l}11 / 14 / 84 \\
01 / 08 / 85 \\
04 / 23 / 85 \\
07 / 10 / 85 \\
11 / 19 / 85 \\
05 / 14 / 86 \\
11 / 13 / 86\end{array}$ & $\begin{array}{l}44.39 \\
42.62 \\
45.65 \\
43.80 \\
48.80 \\
42.60 \\
44.00\end{array}$ \\
\hline
\end{tabular}


Table 1.--Well information and water levels from selected wells in Williams County, Ohio---Continued

\begin{tabular}{|c|c|c|c|c|c|c|}
\hline $\begin{array}{l}\text { Local } \\
\text { well } \\
\text { number }\end{array}$ & Site number & Owner & $\begin{array}{l}\text { Depth } \\
\text { of well } \\
\text { (feet) }^{1}\end{array}$ & $\begin{array}{c}\text { Altitude } \\
\text { (feet above } \\
\text { sea level) }\end{array}$ & Date & $\begin{array}{l}\text { Water } \\
\text { level } \\
\text { (feet) }^{1}\end{array}$ \\
\hline WM- $62-\mathrm{K} 10$ & 413458084372200 & $\begin{array}{l}\text { City of } \\
\text { Montpelier }\end{array}$ & -- & 850 & $\begin{array}{l}11 / 14 / 84 \\
01 / 08 / 85 \\
04 / 17 / 85 \\
07 / 09 / 85 \\
11 / 05 / 85 \\
05 / 13 / 86 \\
11 / 13 / 86\end{array}$ & $\begin{array}{r}8.57 \\
7.49 \\
18.52 \\
16.30 \\
16.10 \\
16.10 \\
11.20\end{array}$ \\
\hline WM- 63-I10 & 413525084364200 & M. DeGroff & 58 & 850 & $\begin{array}{l}11 / 14 / 84 \\
01 / 08 / 85 \\
04 / 23 / 85 \\
07 / 09 / 85 \\
11 / 05 / 85 \\
05 / 13 / 86 \\
11 / 13 / 86\end{array}$ & $\begin{array}{l}18.40 \\
17.60 \\
19.30 \\
21.50 \\
21.45 \\
20.70 \\
19.80\end{array}$ \\
\hline$W M-64-L 5$ & 413604084423800 & R. Gilbert & 85 & 910 & $\begin{array}{l}11 / 14 / 84 \\
01 / 08 / 85 \\
04 / 24 / 85 \\
07 / 09 / 85 \\
11 / 05 / 85 \\
05 / 13 / 86 \\
11 / 13 / 86\end{array}$ & $\begin{array}{l}34.28 \\
33.26 \\
32.30 \\
38.50 \\
34.32 \\
33.70 \\
34.55\end{array}$ \\
\hline WM-65-I5 & 413315084423800 & M. Tingley & 45 & 865 & $\begin{array}{l}11 / 14 / 84 \\
01 / 08 / 85 \\
04 / 17 / 85 \\
07 / 10 / 85 \\
11 / 05 / 85 \\
05 / 13 / 86 \\
11 / 13 / 86\end{array}$ & $\begin{array}{l}14.33 \\
13.25 \\
13.20 \\
17.25 \\
34.32 \\
33.70 \\
34.55\end{array}$ \\
\hline$W M-66-G 4$ & 413139084435400 & L. Gearhart & 65 & 875 & $\begin{array}{l}11 / 14 / 84 \\
01 / 08 / 85 \\
04 / 17 / 85 \\
07 / 10 / 85 \\
11 / 05 / 85 \\
05 / 13 / 86 \\
11 / 13 / 86\end{array}$ & $\begin{array}{l}37.48 \\
36.95 \\
36.85 \\
38.09 \\
39.20 \\
38.60 \\
39.10\end{array}$ \\
\hline$W M-67-I 1$ & 413526084481300 & J. Hadix & 76 & 940 & $\begin{array}{l}11 / 14 / 84 \\
01 / 08 / 85 \\
04 / 17 / 85 \\
07 / 09 / 85 \\
11 / 05 / 85 \\
05 / 13 / 86 \\
11 / 13 / 86\end{array}$ & $\begin{array}{l}21.55 \\
19.83 \\
19.95 \\
19.00 \\
21.60 \\
20.00 \\
21.10\end{array}$ \\
\hline
\end{tabular}


Table 1.--Well information and water levels from selected wells in williams County, Ohio--Continued

\begin{tabular}{|c|c|c|c|c|c|c|}
\hline $\begin{array}{l}\text { Local } \\
\text { well } \\
\text { number }\end{array}$ & Site number & Owner & $\begin{array}{l}\text { Depth } \\
\text { of well } \\
\text { (feet) }^{1}\end{array}$ & $\begin{array}{c}\text { Altitude } \\
\text { (feet above } \\
\text { sea level) }\end{array}$ & Date & $\begin{array}{l}\text { Water } \\
\text { level } \\
\text { (feet) }^{1}\end{array}$ \\
\hline$W M-68-M 3$ & 413635084453800 & Patterson & 63 & 950 & $\begin{array}{l}11 / 14 / 84 \\
01 / 08 / 85 \\
04 / 23 / 85 \\
07 / 09 / 85 \\
11 / 05 / 85 \\
05 / 13 / 86 \\
11 / 13 / 86\end{array}$ & $\begin{array}{l}38.65 \\
38.82 \\
38.20 \\
38.40 \\
38.95 \\
38.70 \\
39.00\end{array}$ \\
\hline$W M-69-J 2$ & 413325084470700 & M. Meyers & 63 & 905 & $\begin{array}{l}01 / 08 / 85 \\
04 / 17 / 85 \\
07 / 10 / 85 \\
11 / 05 / 85 \\
11 / 14 / 85 \\
05 / 13 / 86 \\
11 / 13 / 86\end{array}$ & $\begin{array}{l}26.38 \\
26.60 \\
26.60 \\
28.25 \\
16.22 \\
25.90 \\
24.80\end{array}$ \\
\hline$W M-70-13$ & 413313084470700 & $\begin{array}{l}\text { Village of } \\
\text { Edon }\end{array}$ & 137 & 900 & $\begin{array}{l}11 / 14 / 84 \\
01 / 08 / 85 \\
04 / 17 / 85 \\
07 / 10 / 85 \\
11 / 05 / 85 \\
05 / 13 / 86 \\
11 / 13 / 86\end{array}$ & $\begin{array}{l}60.48 \\
14.63 \\
15.00 \\
55.80 \\
16.60 \\
18.00 \\
18.00\end{array}$ \\
\hline WM-71-F13 & 413050084355200 & G. Beucler & 52 & 810 & $\begin{array}{l}11 / 15 / 84 \\
01 / 08 / 85 \\
04 / 23 / 85 \\
07 / 10 / 85 \\
08 / 13 / 85 \\
11 / 06 / 85 \\
05 / 14 / 86 \\
11 / 13 / 86\end{array}$ & $\begin{array}{l}23.88 \\
23.80 \\
23.18 \\
24.20 \\
25.49 \\
24.69 \\
22.30 \\
22.10\end{array}$ \\
\hline WM-72-F21 & 413040084250800 & $\begin{array}{r}\text { City of } \\
\text { Bryan }\end{array}$ & -- & 715 & $\begin{array}{l}01 / 07 / 85 \\
04 / 16 / 85 \\
07 / 08 / 85 \\
08 / 12 / 85 \\
11 / 06 / 85 \\
05 / 12 / 86 \\
11 / 12 / 86\end{array}$ & $\begin{array}{l}38.02 \\
28.70 \\
14.00 \\
32.44 \\
28.50 \\
13.80 \\
20.70\end{array}$ \\
\hline WM- 73-A6 & 412536084413300 & E. Hahn & 247 & 850 & $\begin{array}{l}12 / 04 / 84 \\
04 / 16 / 85 \\
07 / 10 / 85 \\
11 / 05 / 85 \\
05 / 13 / 86 \\
11 / 13 / 86\end{array}$ & $\begin{array}{l}52.58 \\
50.29 \\
52.40 \\
53.40 \\
52.60 \\
56.00\end{array}$ \\
\hline
\end{tabular}


Table 1.--Well information and water levels from selected wells in williams County, Ohio--Continued

\begin{tabular}{|c|c|c|c|c|c|c|}
\hline $\begin{array}{l}\text { Local } \\
\text { well } \\
\text { number }\end{array}$ & Site number & Owner & $\begin{array}{l}\text { Depth } \\
\text { of well } \\
\text { (feet) }\end{array}$ & $\begin{array}{l}\text { Altitude } \\
\text { (feet above } \\
\text { sea level) }\end{array}$ & Date & $\begin{array}{l}\text { Water } \\
\text { level } \\
\text { (feet) }\end{array}$ \\
\hline WM-74-A5 & 412535084432200 & D. Hamman & 124 & 850 & $\begin{array}{l}11 / 14 / 84 \\
01 / 08 / 85 \\
04 / 17 / 85 \\
05 / 13 / 85 \\
07 / 10 / 85 \\
11 / 13 / 86\end{array}$ & $\begin{array}{l}16.22 \\
26.38 \\
26.60 \\
44.80 \\
26.60 \\
45.50\end{array}$ \\
\hline WM-75-A4 & 412613084445300 & L. Mason & 74 & 835 & $\begin{array}{l}12 / 04 / 84 \\
01 / 09 / 85 \\
04 / 16 / 85 \\
07 / 10 / 85 \\
11 / 05 / 85 \\
05 / 13 / 86 \\
11 / 13 / 86\end{array}$ & $\begin{array}{l}23.20 \\
21.28 \\
20.12 \\
23.73 \\
24.40 \\
23.30 \\
23.70\end{array}$ \\
\hline $\mathrm{WM}-76-\mathrm{E} 1$ & 412903084474200 & K. Dietsch & 76 & 870 & $\begin{array}{l}12 / 04 / 84 \\
01 / 08 / 85 \\
04 / 16 / 85 \\
07 / 10 / 85 \\
11 / 05 / 85 \\
05 / 13 / 86 \\
11 / 12 / 86\end{array}$ & $\begin{array}{l}27.32 \\
26.18 \\
25.63 \\
27.70 \\
27.86 \\
27.40 \\
27.70\end{array}$ \\
\hline WM-77-E6 & 412944084420700 & J. Hug & 108 & 860 & $\begin{array}{l}12 / 04 / 84 \\
01 / 08 / 85 \\
04 / 16 / 85 \\
07 / 10 / 85 \\
11 / 05 / 85 \\
05 / 13 / 86 \\
11 / 13 / 86\end{array}$ & $\begin{array}{l}45.70 \\
44.44 \\
42.93 \\
44.72 \\
45.72 \\
44.20 \\
45.80\end{array}$ \\
\hline WM-78-B4 & 412707084442600 & $\begin{array}{r}\text { Village of } \\
\text { Edgerton }\end{array}$ & -- & 835 & $\begin{array}{l}12 / 05 / 84 \\
01 / 09 / 85 \\
04 / 16 / 85 \\
07 / 10 / 85 \\
08 / 13 / 85 \\
11 / 05 / 85 \\
05 / 13 / 86 \\
11 / 13 / 86\end{array}$ & $\begin{array}{l}24.34 \\
22.79 \\
20.33 \\
23.20 \\
24.05 \\
26.10 \\
26.30 \\
40.80\end{array}$ \\
\hline WM-79-M14 & 413637084331800 & Holiday Inn & -- & 900 & $\begin{array}{l}01 / 07 / 85 \\
04 / 24 / 85 \\
07 / 09 / 85 \\
11 / 06 / 85 \\
05 / 14 / 86 \\
11 / 13 / 86\end{array}$ & $\begin{array}{l}61.42 \\
62.30 \\
65.45 \\
64.60 \\
69.50 \\
64.50\end{array}$ \\
\hline
\end{tabular}


Table 1.--Well information and water levels from selected wells in williams County, Ohio--Continued

\begin{tabular}{|c|c|c|c|c|c|c|}
\hline $\begin{array}{l}\text { Local } \\
\text { well } \\
\text { number }\end{array}$ & Site number & Owner & $\begin{array}{l}\text { Depth } \\
\text { of well } \\
(\text { feet })^{1}\end{array}$ & $\begin{array}{l}\text { Altitude } \\
\text { (feet above } \\
\text { sea level) }\end{array}$ & Date & $\begin{array}{l}\text { Water } \\
\text { level } \\
\text { (feet) }^{1}\end{array}$ \\
\hline WM-80-D14 & 412907084321800 & K. Pettit & -- & 755 & $\begin{array}{l}12 / 05 / 84 \\
01 / 07 / 85 \\
04 / 24 / 85 \\
07 / 10 / 85 \\
11 / 06 / 85 \\
05 / 14 / 86 \\
11 / 12 / 86\end{array}$ & $\begin{array}{l}29.00 \\
21.00 \\
29.36 \\
35.13 \\
31.40 \\
31.20 \\
26.50\end{array}$ \\
\hline WM-81-K11 & 413452084363100 & $\begin{array}{l}\text { City of } \\
\text { Montpelier }\end{array}$ & -- & 875 & $\begin{array}{l}01 / 08 / 85 \\
04 / 17 / 85 \\
07 / 09 / 85 \\
11 / 05 / 85 \\
05 / 13 / 86 \\
11 / 13 / 86\end{array}$ & $\begin{array}{l}67.00 \\
71.00 \\
73.00 \\
72.00 \\
72.00 \\
74.00\end{array}$ \\
\hline$W M-82-07$ & 414043084405900 & F. Boyer & 93 & 955 & $\begin{array}{l}03 / 27 / 85 \\
04 / 17 / 85 \\
07 / 09 / 85 \\
11 / 05 / 85 \\
05 / 13 / 86 \\
11 / 13 / 86\end{array}$ & $\begin{array}{l}28.90 \\
28.90 \\
29.47 \\
29.20 \\
28.90 \\
29.50\end{array}$ \\
\hline$W M-83-08$ & 413842084401000 & D. st. John & 83 & 915 & $04 / 23 / 85$ & 7.00 \\
\hline WM-84A-H21 & 413209084242801 & E. Graber & -- & 725 & $\begin{array}{l}07 / 08 / 85 \\
11 / 06 / 85 \\
05 / 12 / 86 \\
11 / 12 / 86\end{array}$ & $\begin{array}{l}15.45 \\
15.50 \\
15.50 \\
15.80\end{array}$ \\
\hline WM-85-N21 & 413730084255400 & W. Grau & 75 & 815 & $\begin{array}{l}04 / 01 / 85 \\
07 / 08 / 85 \\
11 / 06 / 85 \\
05 / 12 / 86 \\
11 / 12 / 86\end{array}$ & $\begin{array}{l}20.00 \\
21.37 \\
20.70 \\
18.70 \\
19.80\end{array}$ \\
\hline WM-86-P17 & 413936084283500 & B. Clark & 112 & 905 & $\begin{array}{l}04 / 18 / 85 \\
07 / 08 / 85 \\
11 / 06 / 85 \\
05 / 12 / 86 \\
11 / 12 / 86\end{array}$ & $\begin{array}{l}42.00 \\
35.50 \\
36.80 \\
39.00 \\
39.60\end{array}$ \\
\hline WM-87-514 & 414150084331000 & K. Becker & 82 & 895 & $\begin{array}{l}04 / 18 / 85 \\
07 / 09 / 85 \\
11 / 06 / 85 \\
05 / 14 / 86 \\
11 / 13 / 86\end{array}$ & $\begin{array}{l}11.36 \\
13.05 \\
13.32 \\
12.30 \\
12.50\end{array}$ \\
\hline
\end{tabular}


Table 1.--Well information and water levels from selected wells in williams County, Ohio--Continued

\begin{tabular}{|c|c|c|c|c|c|c|}
\hline $\begin{array}{l}\text { Local } \\
\text { well } \\
\text { number }\end{array}$ & Site number & Owner & $\begin{array}{l}\text { Depth } \\
\text { of well } \\
(\text { feet })^{1}\end{array}$ & $\begin{array}{c}\text { Altitude } \\
\text { (feet above } \\
\text { sea level) }\end{array}$ & Date & $\begin{array}{l}\text { Water } \\
\text { level } \\
\text { (feet) }^{1}\end{array}$ \\
\hline WM-88-N14 & 413746084323800 & Sauder & 93 & 890 & $\begin{array}{l}04 / 18 / 85 \\
07 / 09 / 85 \\
11 / 06 / 85 \\
05 / 14 / 86 \\
11 / 13 / 86\end{array}$ & $\begin{array}{l}51.90 \\
51.71 \\
51.90 \\
47.40 \\
51.00\end{array}$ \\
\hline WM-89-J7 & 413355084403700 & Overberg & 41 & 865 & $\begin{array}{l}02 / 27 / 85 \\
04 / 17 / 85 \\
07 / 09 / 85 \\
11 / 05 / 85 \\
05 / 13 / 86 \\
11 / 13 / 86\end{array}$ & $\begin{array}{l}11.31 \\
16.70 \\
14.85 \\
13.70 \\
13.60 \\
14.40\end{array}$ \\
\hline$W M-90-F 7$ & 413048084403900 & I. Keesbury & 70 & 855 & $\begin{array}{l}04 / 26 / 85 \\
07 / 10 / 85 \\
11 / 05 / 85 \\
05 / 13 / 86 \\
11 / 13 / 86\end{array}$ & $\begin{array}{l}38.90 \\
30.90 \\
31.22 \\
29.90 \\
30.90\end{array}$ \\
\hline$W M-91-E 7$ & 413043084400100 & o. Wolf & 118 & 860 & $\begin{array}{l}07 / 10 / 85 \\
11 / 05 / 85\end{array}$ & $\begin{array}{l}36.77 \\
36.30\end{array}$ \\
\hline$W M-92-G 12$ & 413141084344400 & Culler & 78 & 840 & $\begin{array}{l}04 / 23 / 85 \\
07 / 10 / 85 \\
11 / 06 / 85 \\
05 / 14 / 86 \\
11 / 13 / 86\end{array}$ & $\begin{array}{l}34.45 \\
36.25 \\
36.86 \\
35.20 \\
36.80\end{array}$ \\
\hline WM-93-C14 & 412802084321400 & $\begin{array}{r}\text { City of } \\
\text { Bryan }\end{array}$ & 122 & 735 & $\begin{array}{l}04 / 16 / 85 \\
07 / 09 / 85 \\
11 / 05 / 85 \\
05 / 13 / 86 \\
11 / 12 / 86\end{array}$ & $\begin{array}{l}28.55 \\
27.20 \\
25.70 \\
29.30 \\
25.70\end{array}$ \\
\hline WM-95-D14 & 412851084322000 & do. & 137 & 755 & $\begin{array}{l}04 / 16 / 85 \\
07 / 09 / 85 \\
11 / 06 / 85 \\
11 / 13 / 86\end{array}$ & $\begin{array}{l}24.75 \\
26.20 \\
34.05 \\
25.70\end{array}$ \\
\hline WM-96-D14 & 412853084322000 & do. & 147 & 755 & $\begin{array}{l}04 / 16 / 85 \\
07 / 09 / 85 \\
11 / 06 / 85 \\
05 / 13 / 86 \\
11 / 13 / 86\end{array}$ & $\begin{array}{l}24.10 \\
37.80 \\
34.75 \\
34.40 \\
25.80\end{array}$ \\
\hline WM-98-G12 & 413053084343400 & $\begin{array}{r}\text { Williams } \\
\text { County }\end{array}$ & -- & 820 & $\begin{array}{l}07 / 10 / 85 \\
11 / 06 / 85 \\
05 / 14 / 86 \\
11 / 13 / 86\end{array}$ & $\begin{array}{l}38.30 \\
37.30 \\
37.10 \\
37.00\end{array}$ \\
\hline
\end{tabular}


Table 1.--Well information and water levels from selected wells in williams County, Ohio--Continued

\begin{tabular}{|c|c|c|c|c|c|c|}
\hline $\begin{array}{l}\text { Local } \\
\text { well } \\
\text { number }\end{array}$ & Site number & Owner & $\begin{array}{l}\text { Depth } \\
\text { of well } \\
(\text { feet })^{1}\end{array}$ & $\begin{array}{c}\text { Altitude } \\
\text { (feet above } \\
\text { sea level) }\end{array}$ & Date & $\begin{array}{l}\text { Water } \\
\text { level } \\
{\text { (feet })^{1}}^{1}\end{array}$ \\
\hline WM-99-B2 & 412651084464100 & B. Blaylock & 177 & 840 & $\begin{array}{l}04 / 16 / 85 \\
07 / 10 / 85 \\
11 / 05 / 85 \\
05 / 13 / 86 \\
11 / 13 / 86\end{array}$ & $\begin{array}{l}21.88 \\
24.98 \\
25.40 \\
24.00 \\
25.70\end{array}$ \\
\hline WM-100-P1 & 413910084473500 & R. Dunlap & 76 & 975 & $\begin{array}{l}04 / 17 / 85 \\
07 / 09 / 85 \\
08 / 13 / 85 \\
11 / 05 / 85 \\
05 / 13 / 86 \\
11 / 13 / 86\end{array}$ & $\begin{array}{l}21.70 \\
22.12 \\
23.52 \\
23.90 \\
22.80 \\
22.50\end{array}$ \\
\hline WM-101-05 & 414029084433000 & F. Dean & 203 & 950 & $\begin{array}{l}04 / 17 / 85 \\
07 / 09 / 85 \\
11 / 05 / 85 \\
05 / 13 / 86 \\
11 / 13 / 86\end{array}$ & $\begin{array}{l}1.50 \\
0.75 \\
0.05 \\
2.50 \\
0.60\end{array}$ \\
\hline WM-102-K20 & 413450084251200 & P. Bleikamp & 76 & 780 & $\begin{array}{l}04 / 18 / 85 \\
07 / 08 / 85 \\
11 / 06 / 85 \\
05 / 12 / 86 \\
11 / 12 / 86\end{array}$ & $\begin{array}{l}28.68 \\
30.40 \\
30.80 \\
28.90 \\
29.30\end{array}$ \\
\hline$W M-103-521$ & 414144084242500 & D. Shaffner & 71 & 850 & $\begin{array}{l}04 / 18 / 85 \\
07 / 08 / 85 \\
11 / 06 / 85 \\
05 / 12 / 86 \\
11 / 12 / 86\end{array}$ & $\begin{array}{l}20.60 \\
24.90 \\
23.00 \\
22.90 \\
23.70\end{array}$ \\
\hline WM-105-A15 & 412556084320900 & R. Sinder & 90 & 730 & $\begin{array}{l}04 / 25 / 85 \\
07 / 11 / 85 \\
11 / 05 / 85\end{array}$ & $\begin{array}{l}5.55 \\
6.70 \\
7.30\end{array}$ \\
\hline WM-107-Q9 & 413957084380300 & Waldron & 83 & 910 & $\begin{array}{l}04 / 17 / 85 \\
07 / 09 / 85 \\
11 / 05 / 85 \\
05 / 13 / 86 \\
11 / 13 / 86\end{array}$ & $\begin{array}{l}6.90 \\
7.73 \\
8.18 \\
7.30 \\
7.70\end{array}$ \\
\hline$W M-108-013$ & 414044084333500 & $\begin{array}{l}\text { Village of } \\
\text { Pioneer }\end{array}$ & 120 & 880 & $\begin{array}{l}08 / 14 / 85 \\
11 / 06 / 85 \\
05 / 14 / 86 \\
11 / 12 / 86\end{array}$ & $\begin{array}{l}16.32 \\
17.66 \\
17.20 \\
17.10\end{array}$ \\
\hline
\end{tabular}

${ }^{1}$ Feet below land-surface datum. 


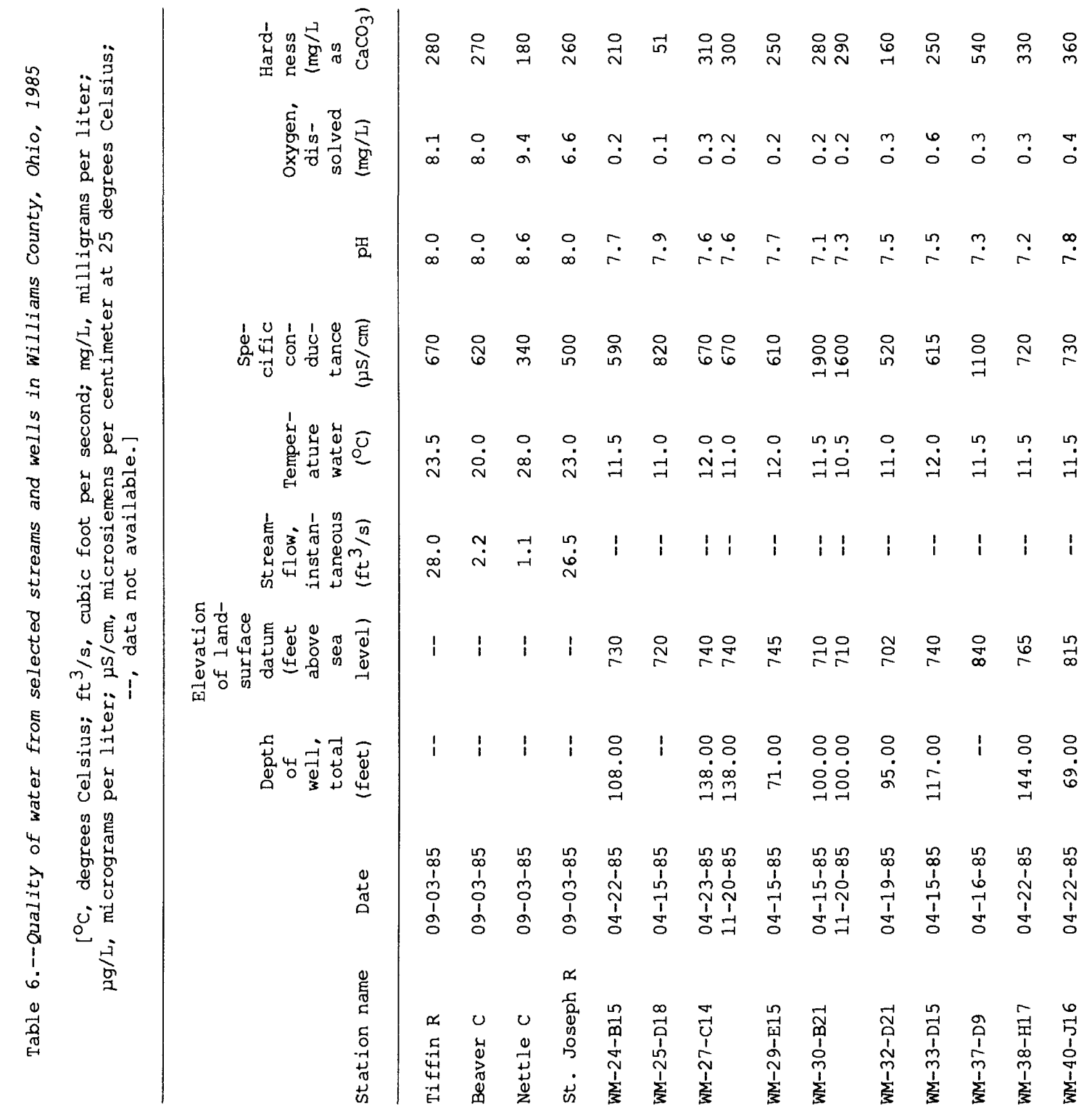




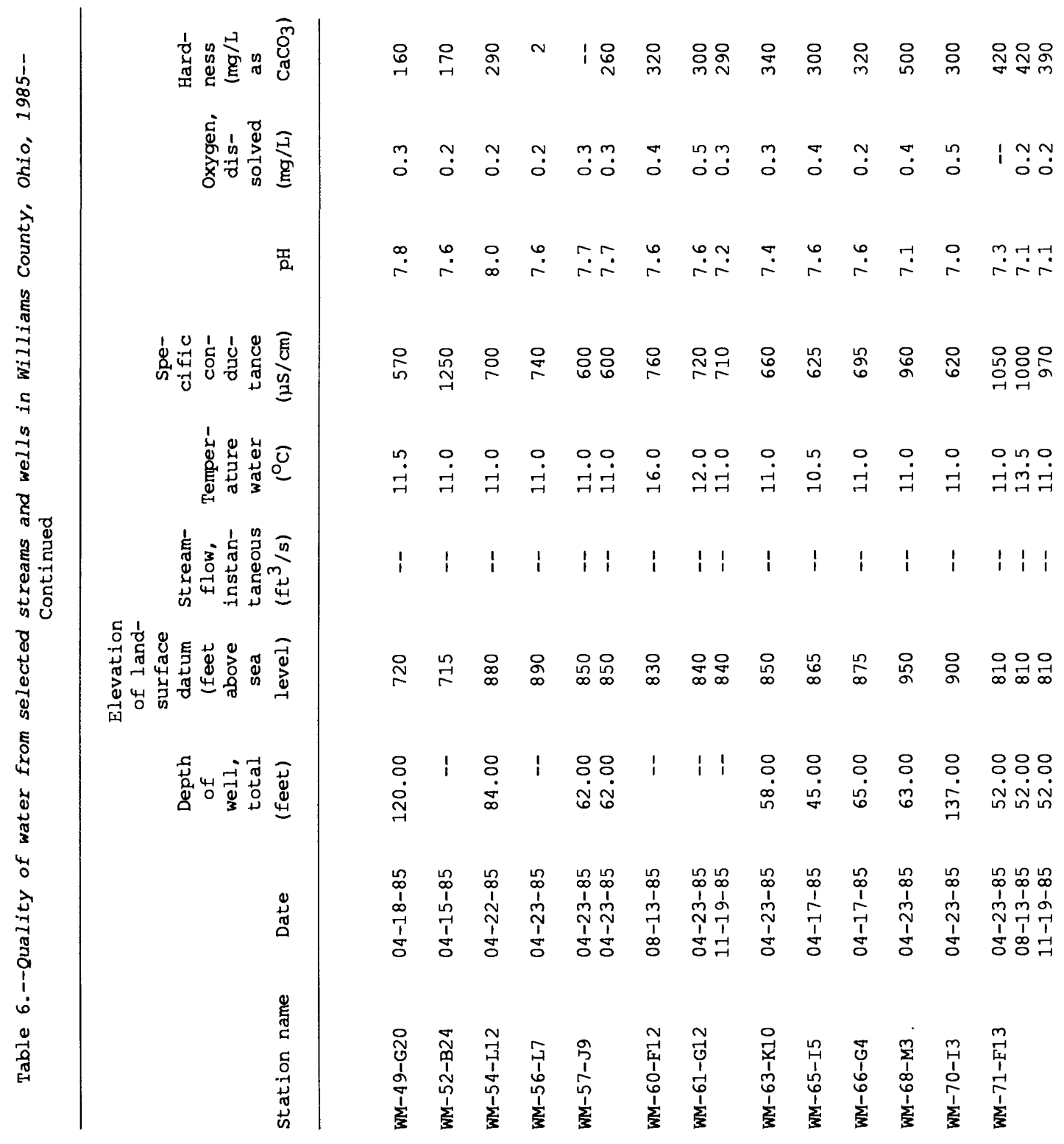




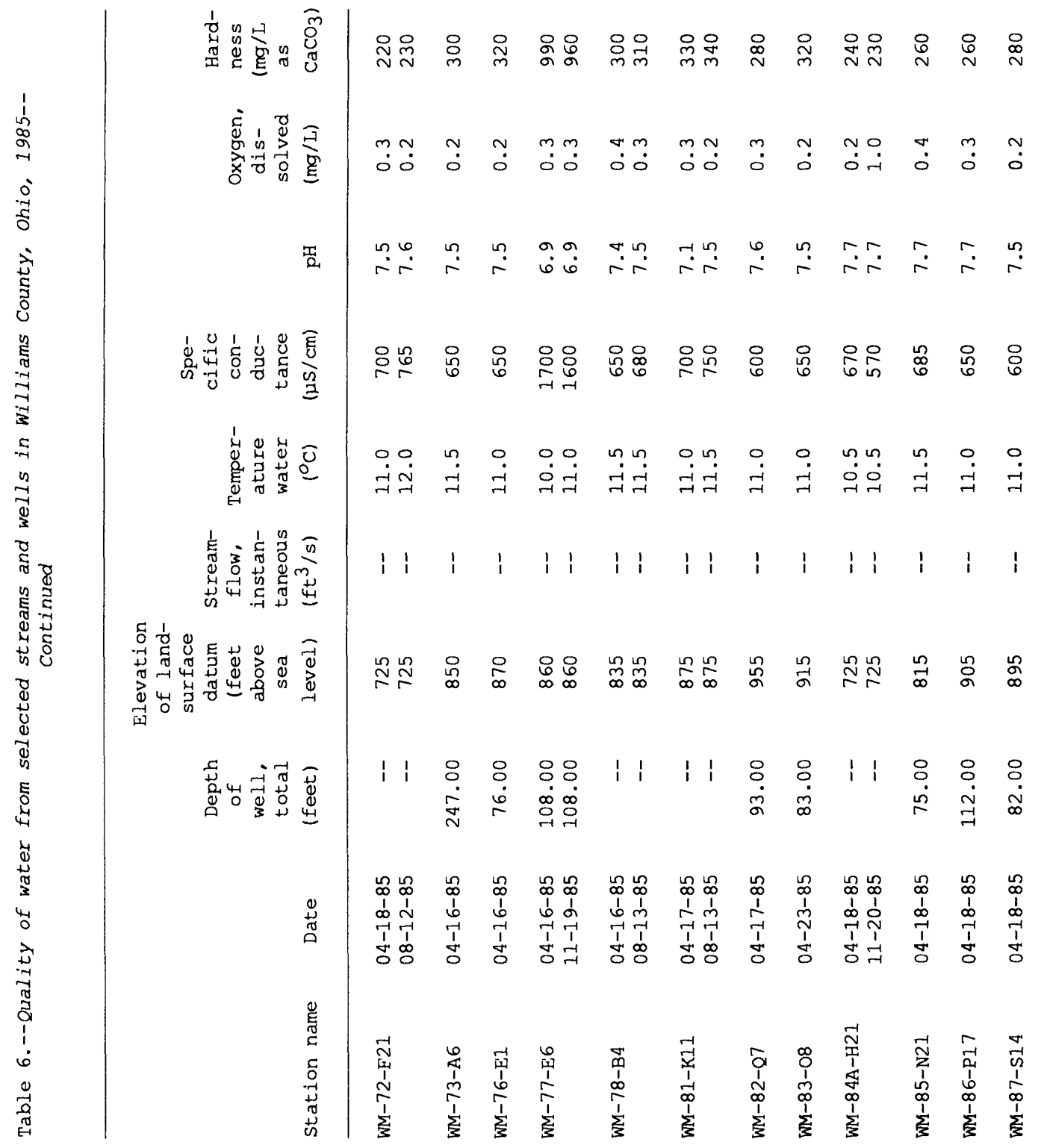




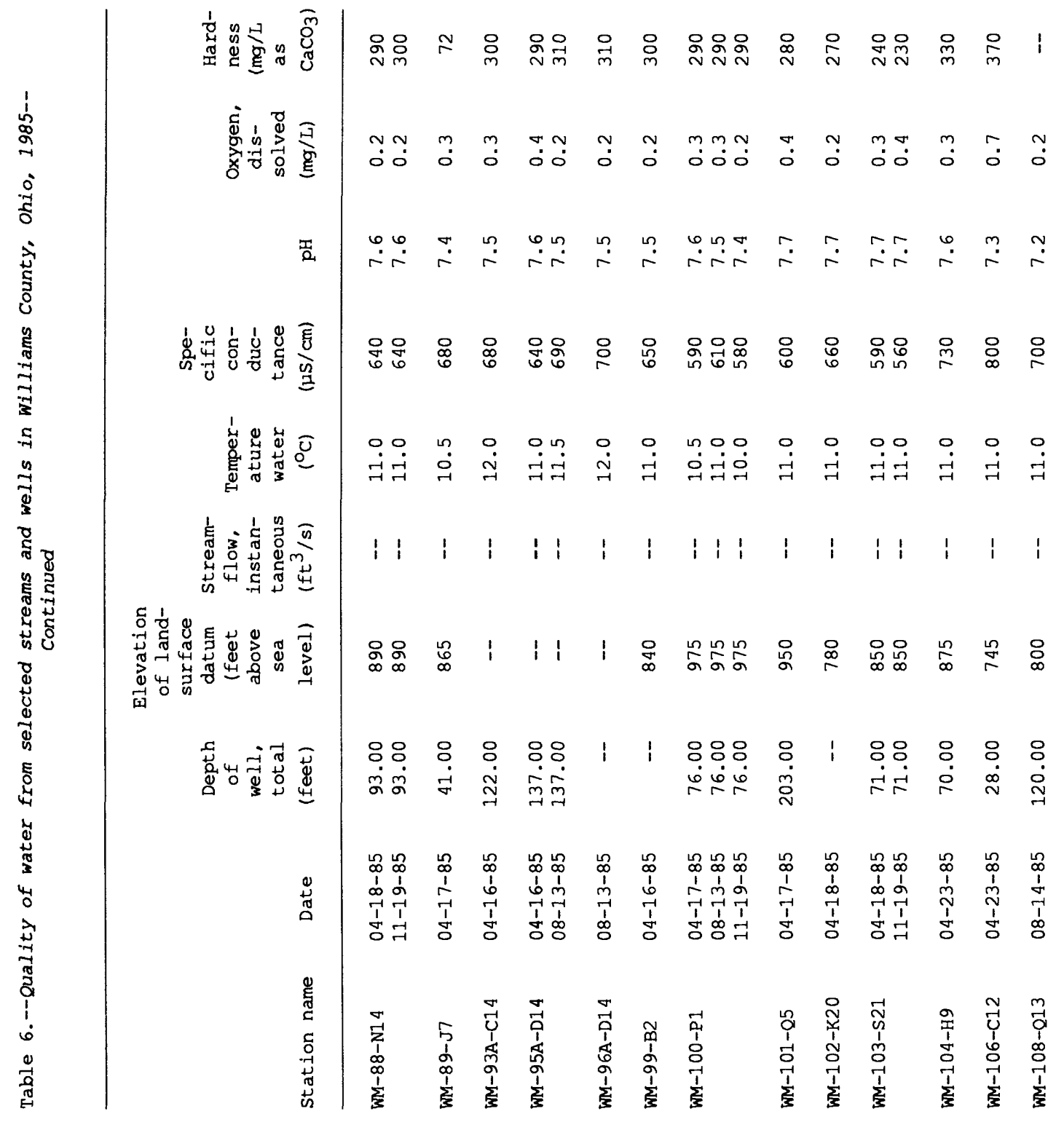




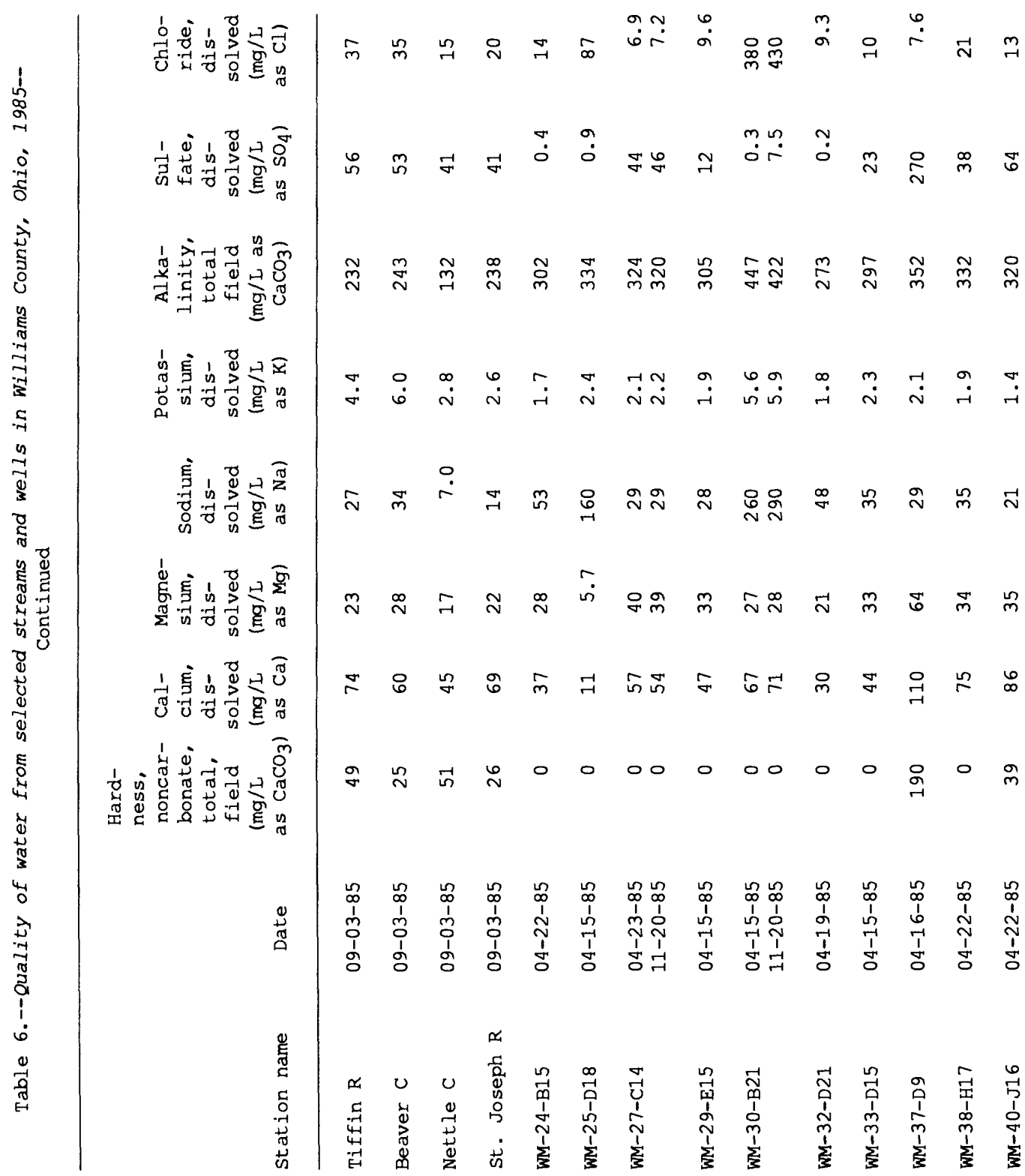




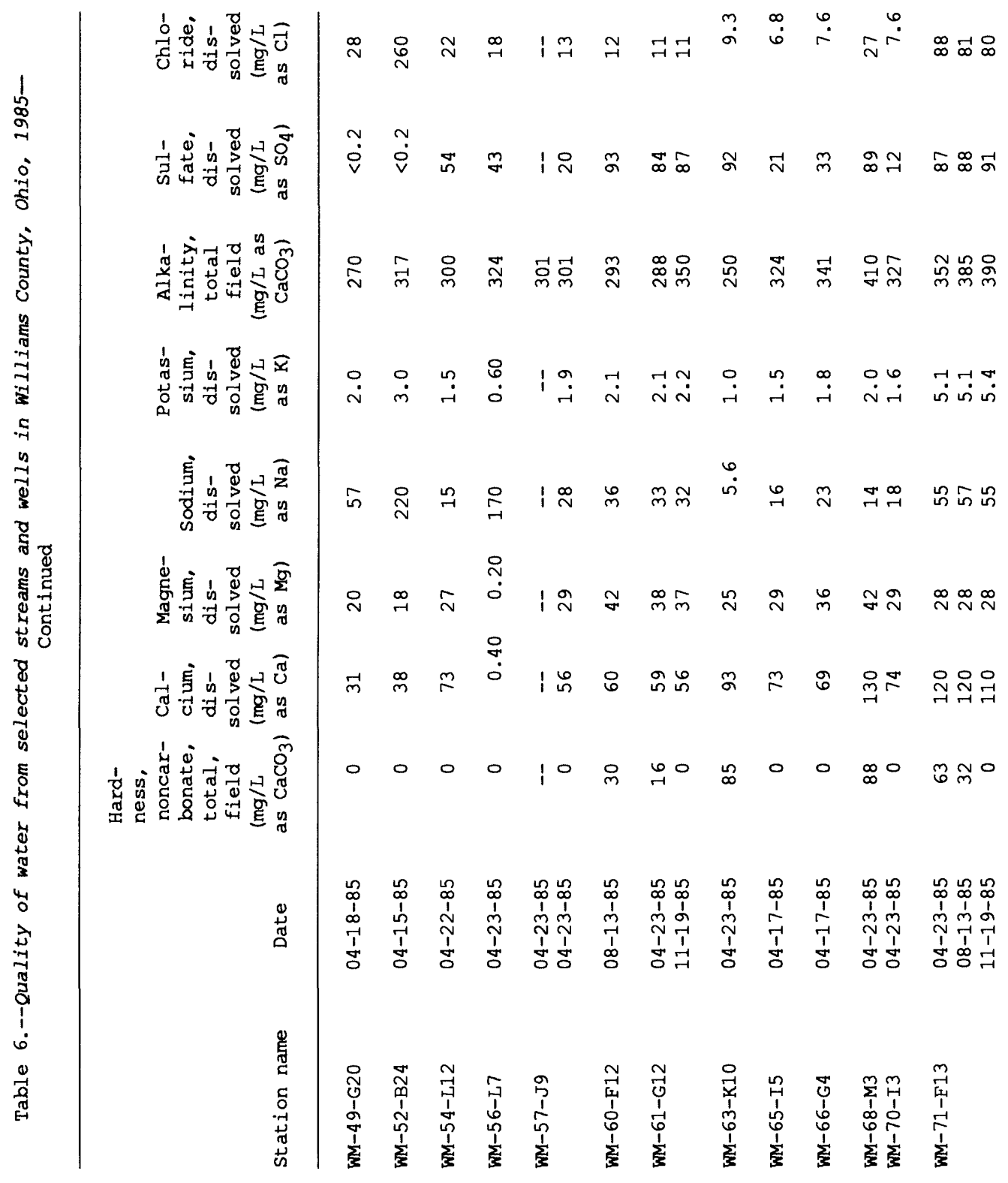




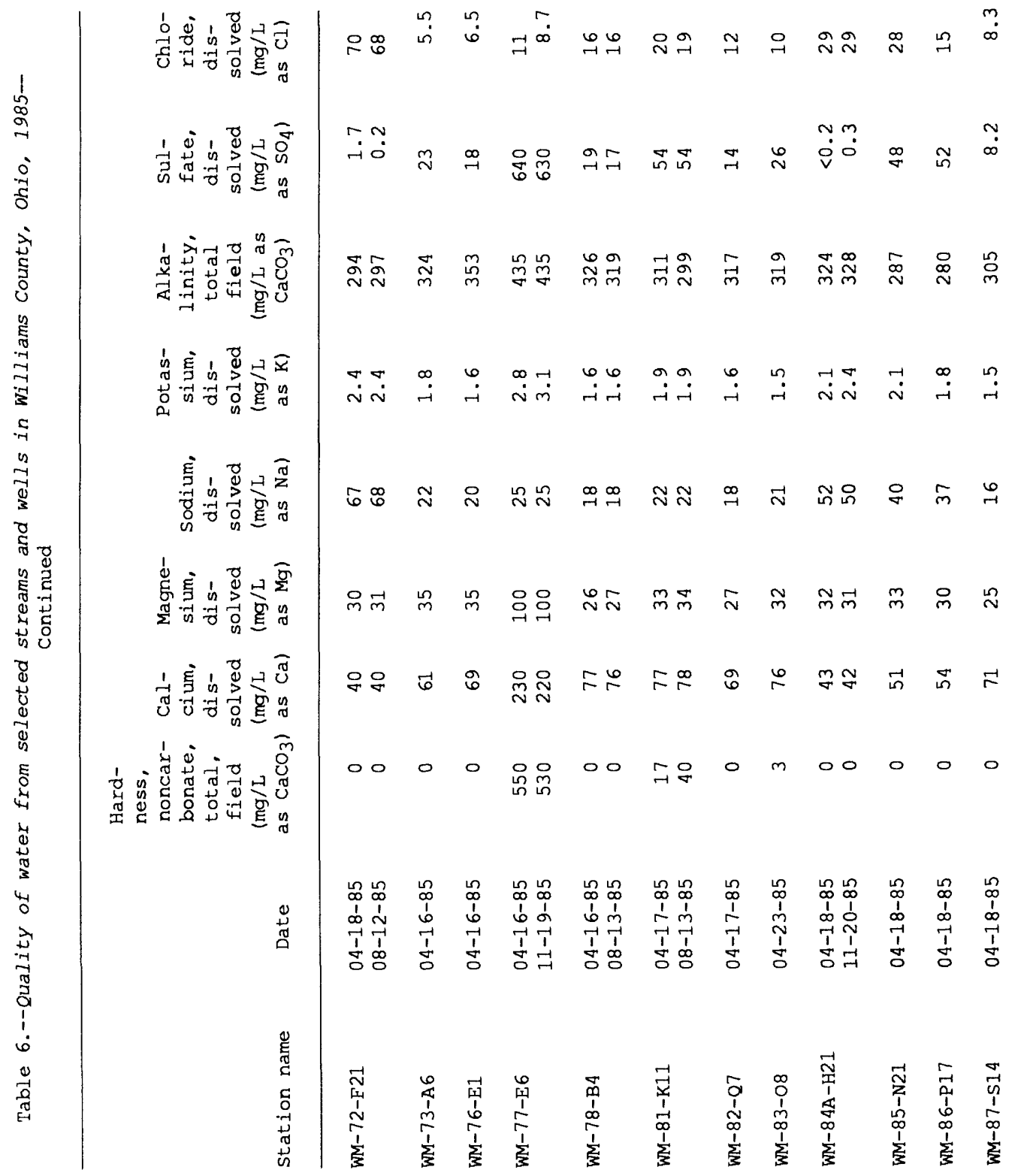




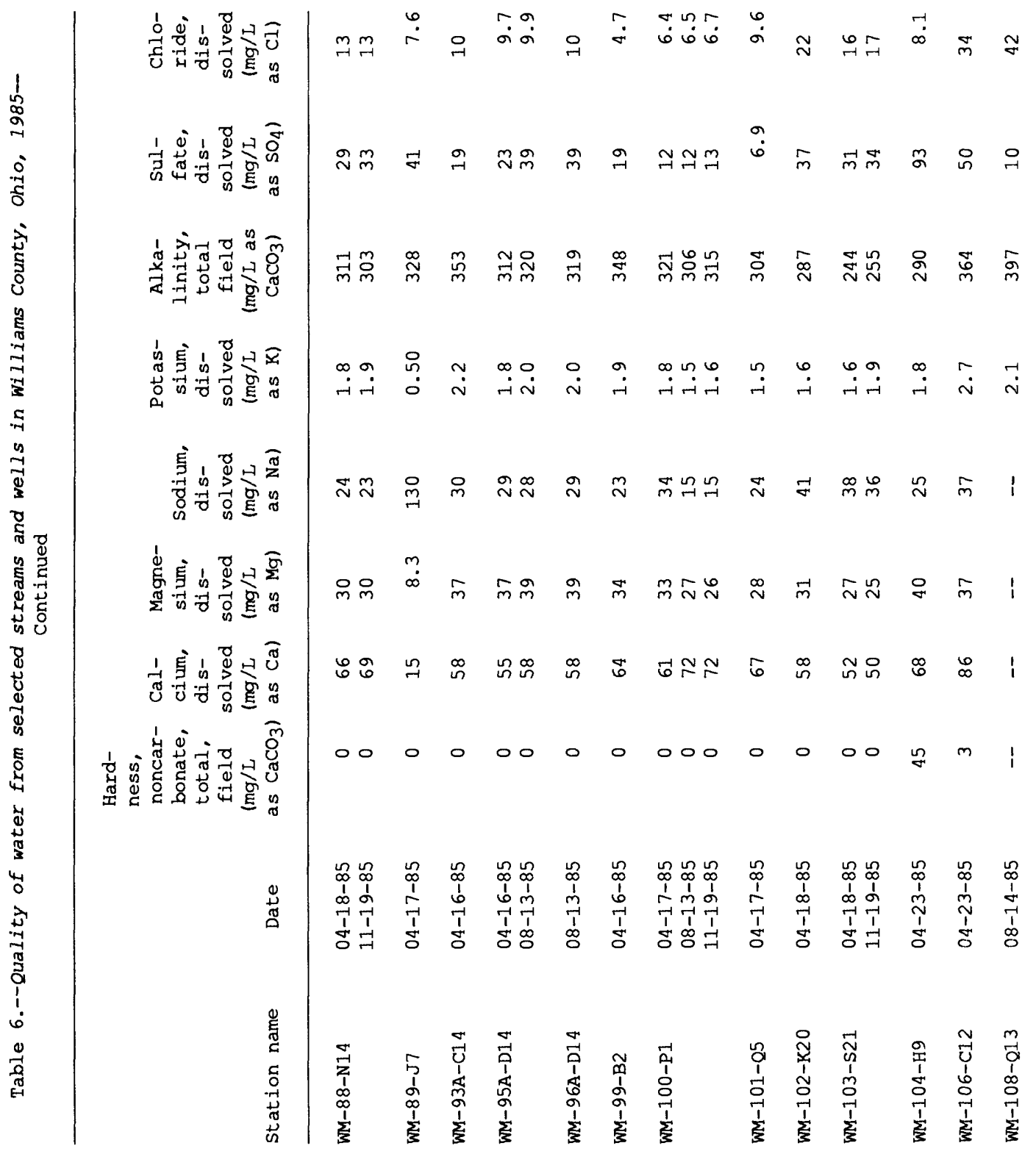




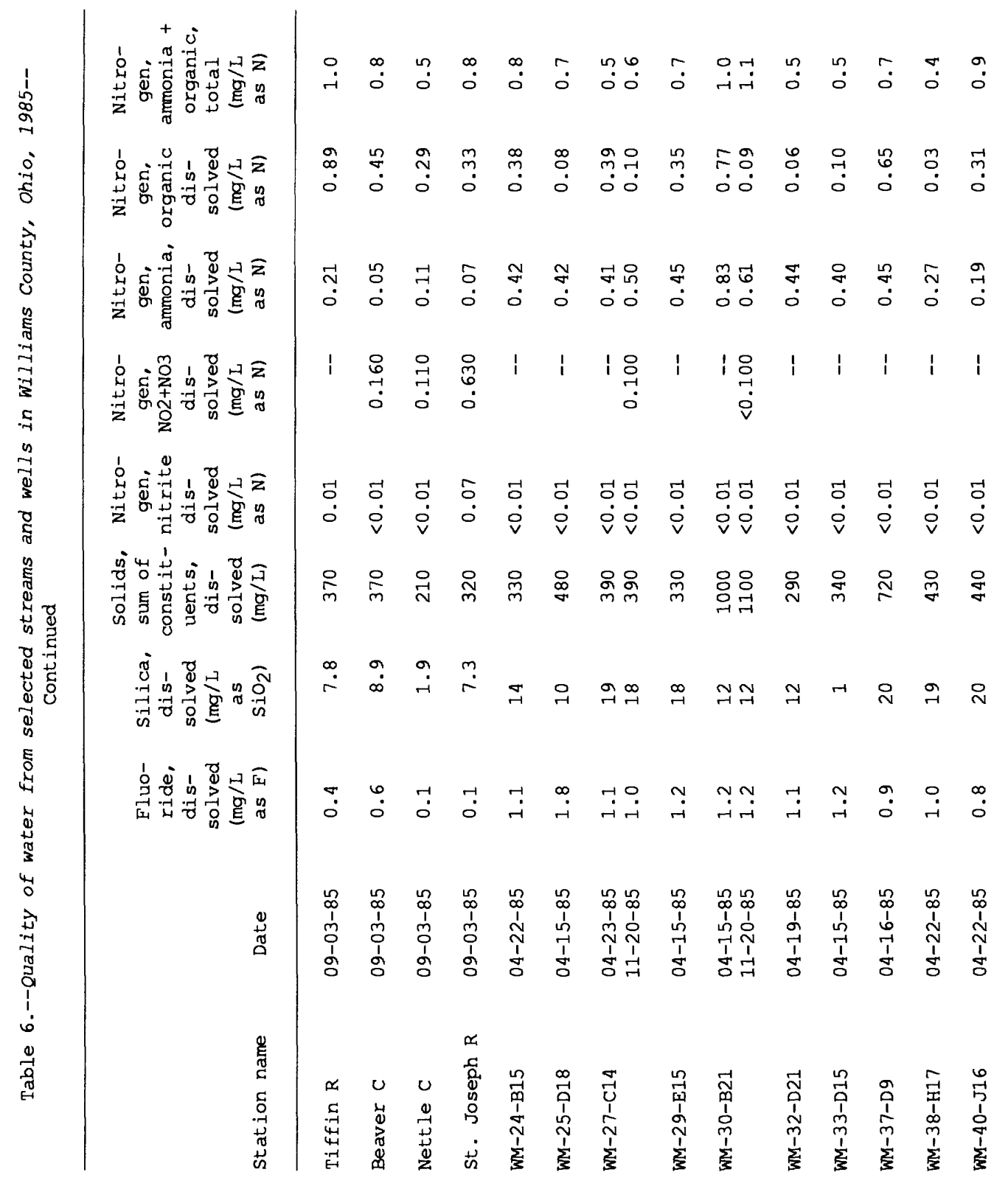




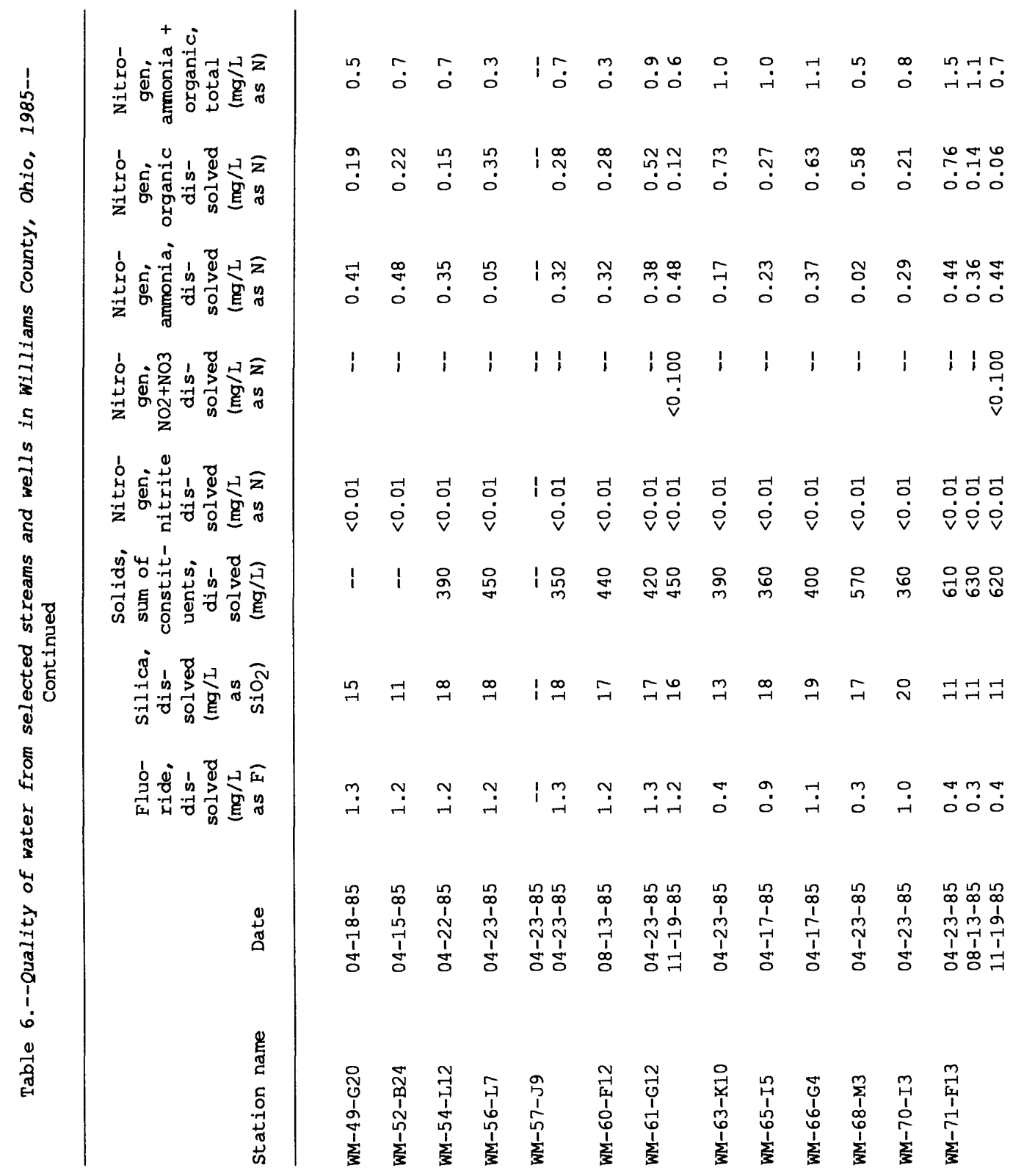




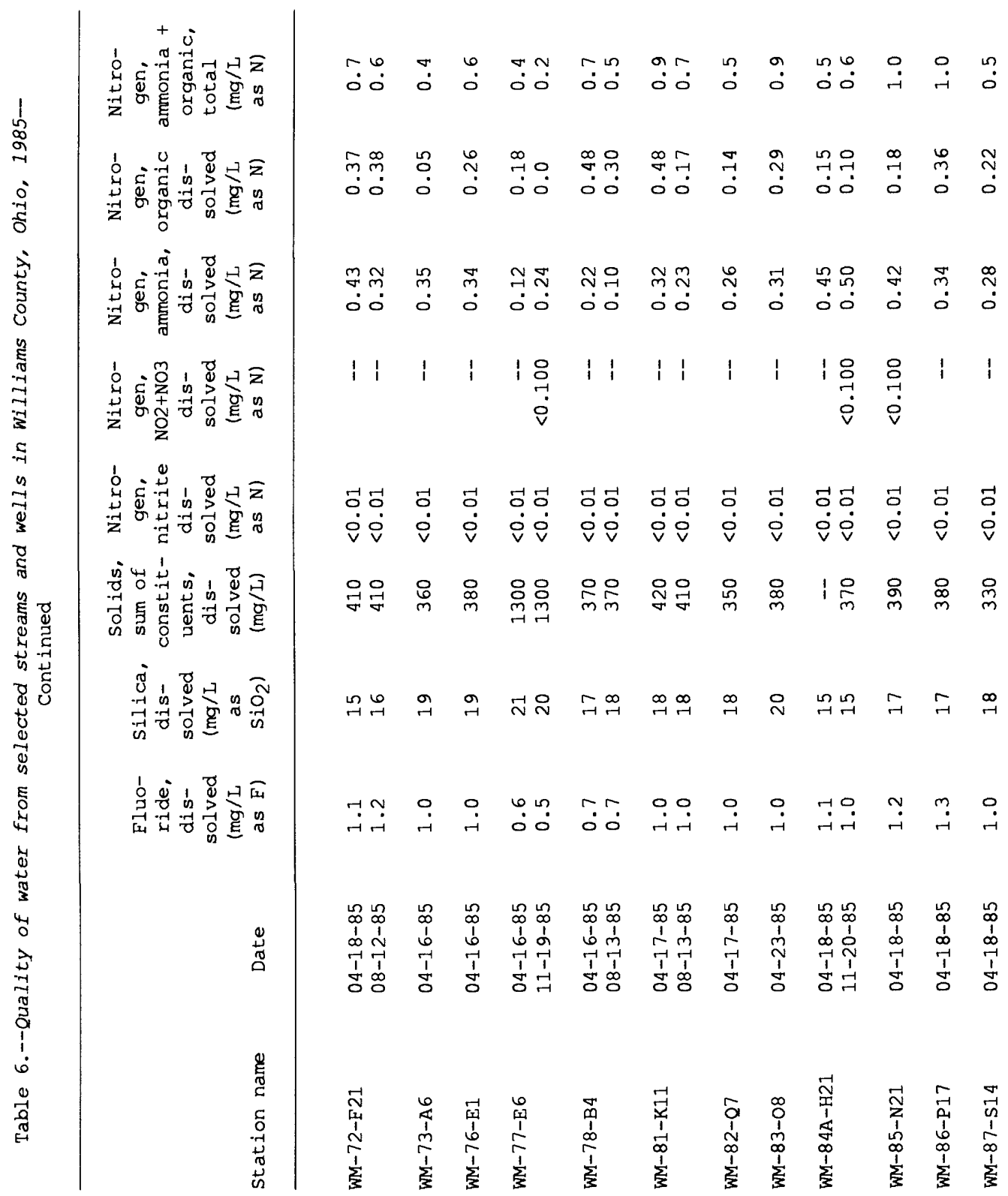




\begin{tabular}{|c|c|c|c|c|c|c|c|c|c|c|c|c|c|c|}
\hline & 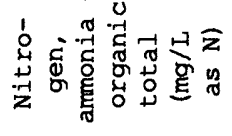 & $\begin{array}{l}\dot{0} \text {. n } \\
\dot{0}\end{array}$ & $\stackrel{9}{0}$ & $\ddot{n}$ & $\begin{array}{ll}0 & 0 \\
0 & 0\end{array}$ & $\ddot{0}$ & $\begin{array}{l}: \\
0\end{array}$ & $\dot{0} \dot{0}$ & $\ddot{n}$ & $\ddot{n}$ & $\ddot{0}: \dot{0}$ & ? & $\stackrel{6}{0}$ & $\stackrel{\nabla}{\circ}$ \\
\hline & 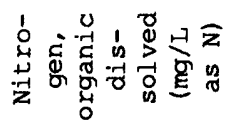 & 吊管 & $\stackrel{\leftrightarrow}{m}$ & $\stackrel{-}{-1}$ & $\stackrel{0}{:-1}$ & $\begin{array}{l}5 \\
\vdots \\
0\end{array}$ & - & 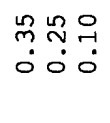 & $\stackrel{\circ}{\circ}$ & $\stackrel{N}{\sim}$ & 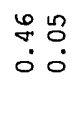 & $\begin{array}{l}0 \\
\stackrel{0}{0} \\
0\end{array}$ & $\begin{array}{l}\mathscr{1} \\
\ddot{0}\end{array}$ & $\stackrel{n}{\sim}$ \\
\hline & 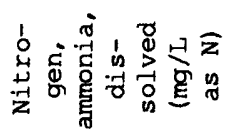 & 㝎 & $\begin{array}{l}\text { \& } \\
\dot{0}\end{array}$ & $\stackrel{m}{\ddot{0}}$ & \begin{tabular}{l}
\multirow{2}{*}{$\tilde{m}$} \\
$\dot{0}$
\end{tabular} & $\stackrel{m}{\stackrel{m}{0}}$ & $\stackrel{\mathscr{m}}{\bullet}$ & $\begin{array}{l}\stackrel{n}{\text { N }} \text { ஸे } \\
\dot{0}\end{array}$ & $\stackrel{m}{!}$ & $\stackrel{\infty}{m}:$ & 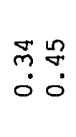 & $\stackrel{\check{m}}{\dot{0}}$ & 峁 & ? \\
\hline & 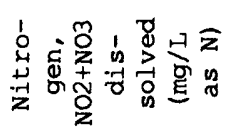 & $\begin{array}{l}18 \\
1 \\
\stackrel{7}{0} \\
8\end{array}$ & $i$ & 1 & 11 & 1 & I & $\begin{array}{ll}1 & 1 \\
& 8 \\
-1 \\
0\end{array}$ & 1 & 1 & $\begin{array}{l}18 \\
1 \\
-1 \\
8\end{array}$ & 1 & 1 & i \\
\hline & 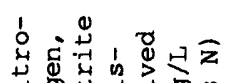 & 동 & - & - & t⿹ & -1 & - & 덩헝형 & t) & ț & t⿹ & - & - & to \\
\hline & 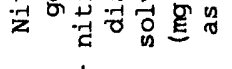 & $\dot{v} \dot{v}$ & $\dot{v}$ & $\dot{v}$ & $\dot{v}^{\circ}$ & $\dot{v}$ & $\dot{v}$ & $\dot{v} \dot{v} \dot{v}$ & $\dot{v}$ & $\dot{v}$ & $\dot{\nabla} \dot{v}$ & $\dot{v}$ & $\dot{v}$ & $\dot{v}$ \\
\hline .్. & 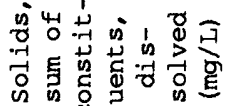 & 只只 & 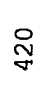 & 㙜 & 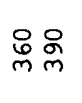 & $\stackrel{\circ}{m}$ & $\stackrel{\infty}{\infty}$ & 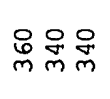 & 品 & $\underset{m}{\infty}$ & 扊品 & 帝 & 요 & 1 \\
\hline 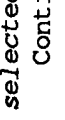 & 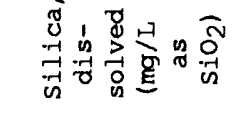 & $\underset{\sim-1}{\infty} \underset{\sim-1}{\infty}$ & $\stackrel{\infty}{\sim}$ & $\stackrel{9}{-}$ & $\rightarrow \stackrel{\infty}{-\infty}$ & $\stackrel{\infty}{\rightarrow}$ & $\underset{-1}{\infty}$ & 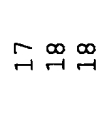 & ने & $\stackrel{\infty}{\rightarrow-1}$ & $\stackrel{\infty}{\rightarrow}$ ન & $\stackrel{\infty}{\rightarrow-1}$ & $\stackrel{\infty}{-1}$ & \\
\hline & 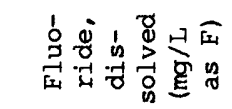 & 울 & $\stackrel{-}{\sim}$ & $\ddot{-}$ & 국 & $\underset{-1}{\sim}$ & $\ddot{-}$ & 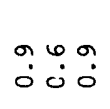 & $\stackrel{-1}{H}$ & $\stackrel{-1}{-1}$ & $\stackrel{\sim}{\sim} \underset{-1}{-1}$ & $\stackrel{-}{\sim}$ & $\stackrel{\circ}{-}$ & $\stackrel{\circ}{-}$ \\
\hline$\vec{\Delta}$ & 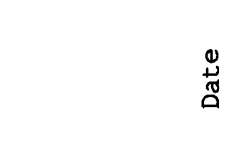 & $\begin{array}{ll}n & n \\
0 & 0 \\
1 & 0 \\
1 & 1 \\
0 & 0 \\
1 & -1 \\
1 & 1 \\
0 & -1\end{array}$ & $\begin{array}{l}n \\
0 \\
1 \\
1 \\
1 \\
1 \\
0\end{array}$ & $\begin{array}{l}u_{0}^{2} \\
0 \\
1 \\
0 \\
1 \\
0 \\
0\end{array}$ & $\begin{array}{ll}n & 0 \\
0 & \infty \\
1 & 1 \\
0 & 1 \\
1 & m \\
1 & 1 \\
0 & 0\end{array}$ & $\begin{array}{l}\stackrel{n}{0} \\
\infty \\
1 \\
m \\
+1 \\
\infty \\
0\end{array}$ & 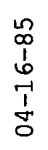 & 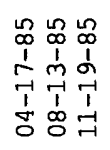 & $\begin{array}{l}2 \\
0 \\
1 \\
\frac{7}{7} \\
1 \\
0\end{array}$ & $\begin{array}{l}n \\
\infty \\
1 \\
\infty \\
1 \\
1 \\
5 \\
0\end{array}$ & $\begin{array}{ll}0 & 0 \\
0 & 0 \\
1 & 0 \\
0 & 0 \\
7 & 9 \\
1 & 7 \\
0 & 1\end{array}$ & $\begin{array}{l}\stackrel{2}{\infty} \\
1 \\
1 \\
\stackrel{1}{N} \\
1 \\
\delta\end{array}$ & $\begin{array}{l}\stackrel{2}{\infty} \\
1 \\
\stackrel{1}{2} \\
\stackrel{1}{+} \\
0\end{array}$ & $\begin{array}{l}0 \\
0 \\
1 \\
+1 \\
71 \\
0 \\
0\end{array}$ \\
\hline & 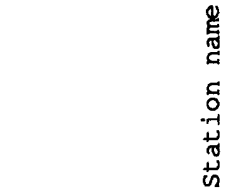 & $\begin{array}{l}\underbrace{}_{1} \\
2 \\
1 \\
\infty \\
\infty \\
0 \\
1 \\
\sum_{3}^{1}\end{array}$ & $\begin{array}{l}5 \\
p \\
1 \\
\infty \\
1 \\
\sum_{3}^{1}\end{array}$ & 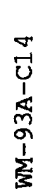 & 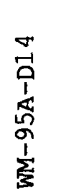 & $\begin{array}{l}\overrightarrow{0} \\
\overrightarrow{0} \\
1 \\
6 \\
o \\
o \\
\sum_{3}^{1}\end{array}$ & 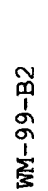 & $\begin{array}{l}-1 \\
0 \\
1 \\
0 \\
0 \\
0 \\
\sum_{5}^{1}\end{array}$ & $\begin{array}{l}{ }_{0}^{2} \\
0 \\
1 \\
0 \\
0 \\
\sum_{3}^{1}\end{array}$ & 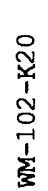 & 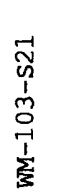 & 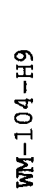 & 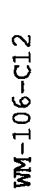 & \begin{tabular}{l}
$m$ \\
\multicolumn{1}{c}{} \\
1 \\
1 \\
0 \\
0 \\
1 \\
$\frac{1}{2}$
\end{tabular} \\
\hline
\end{tabular}




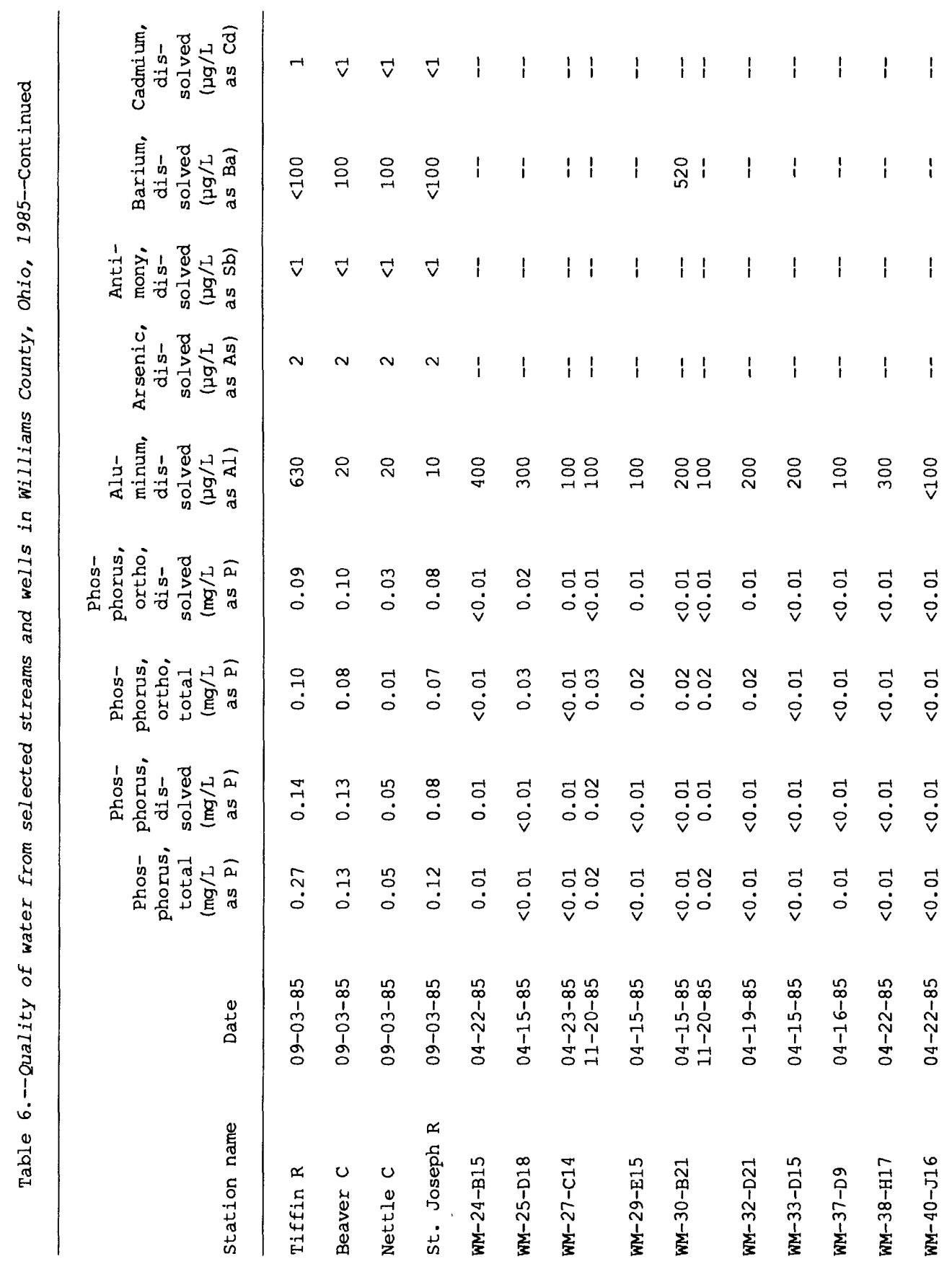




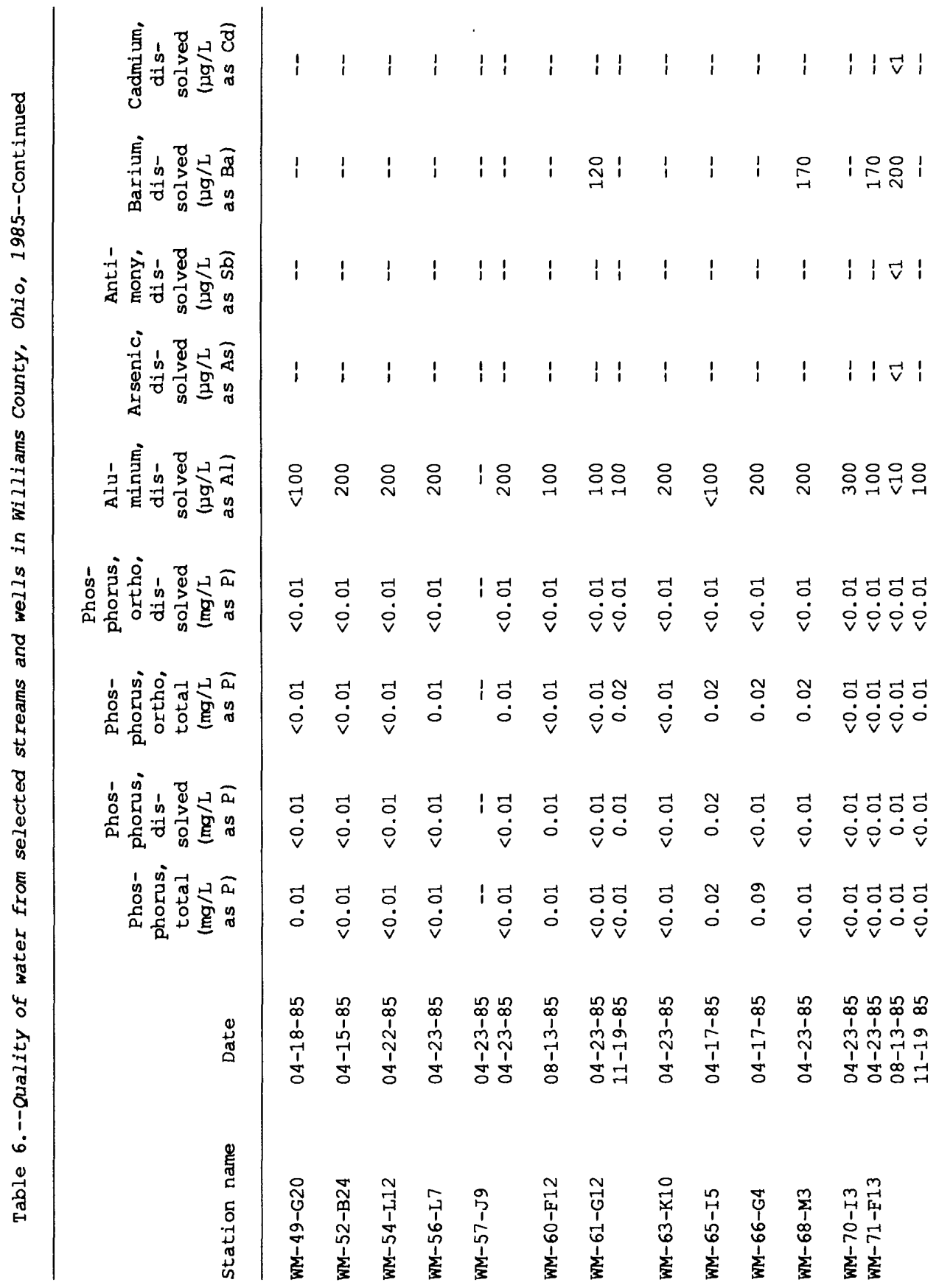




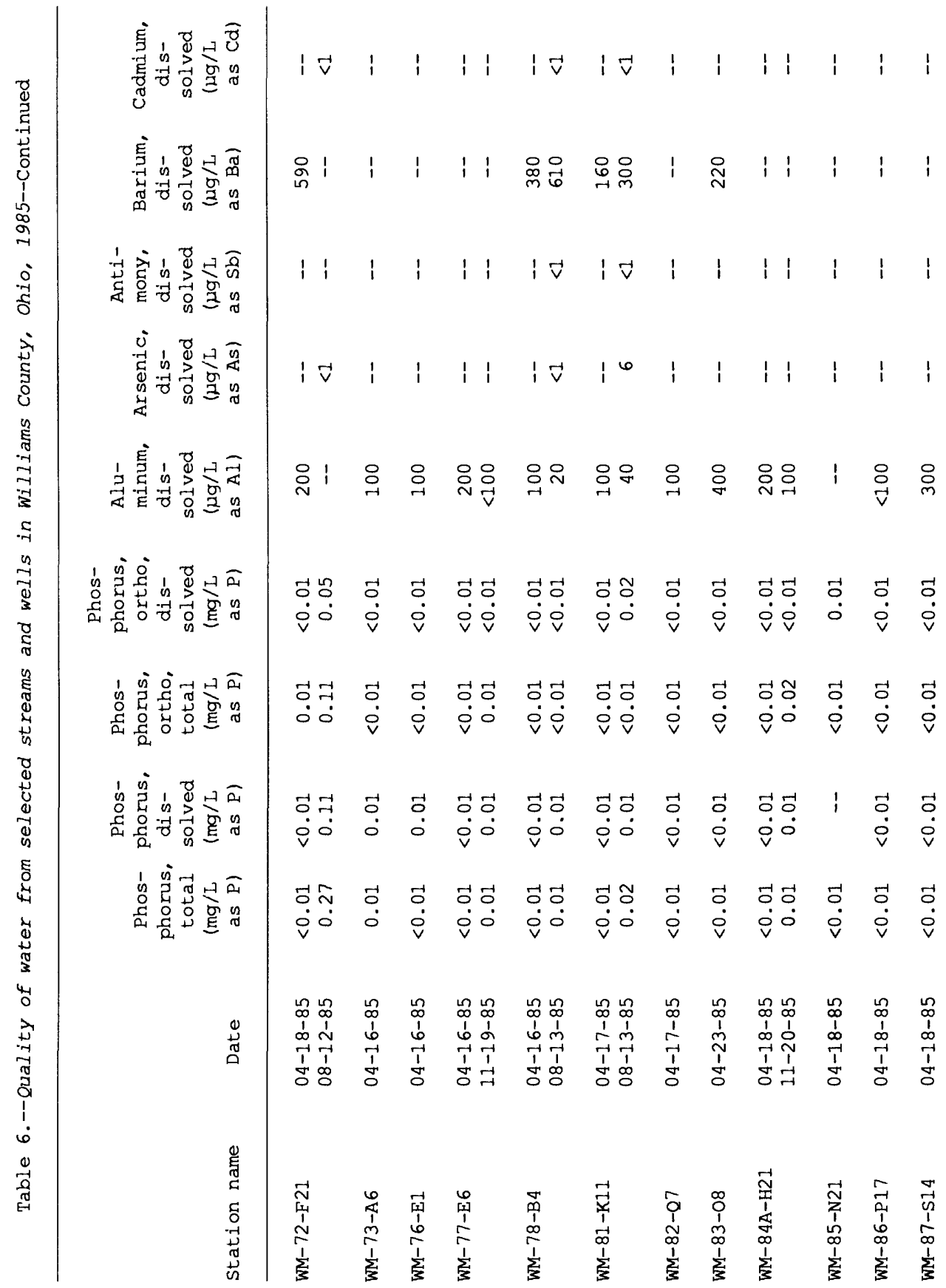




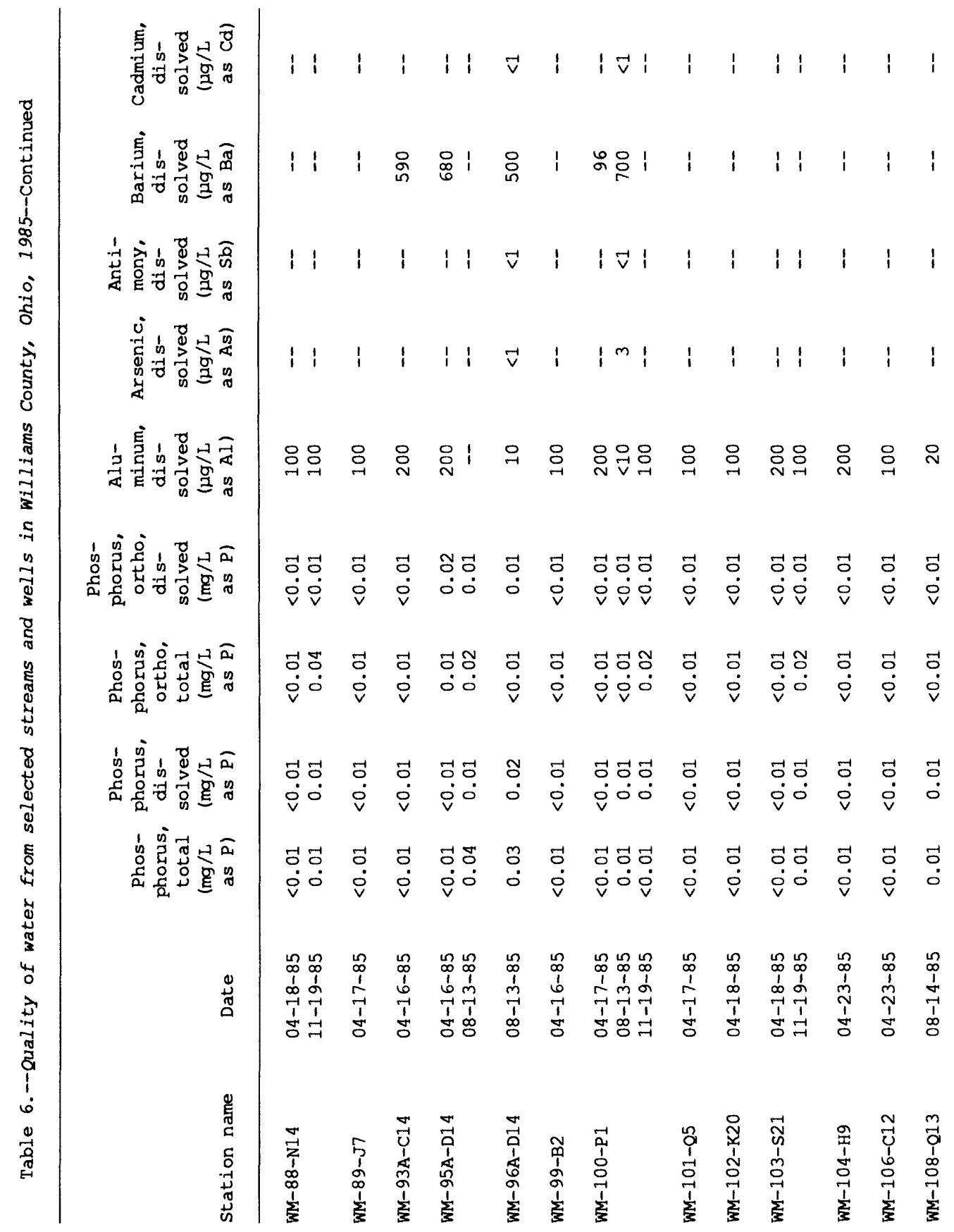




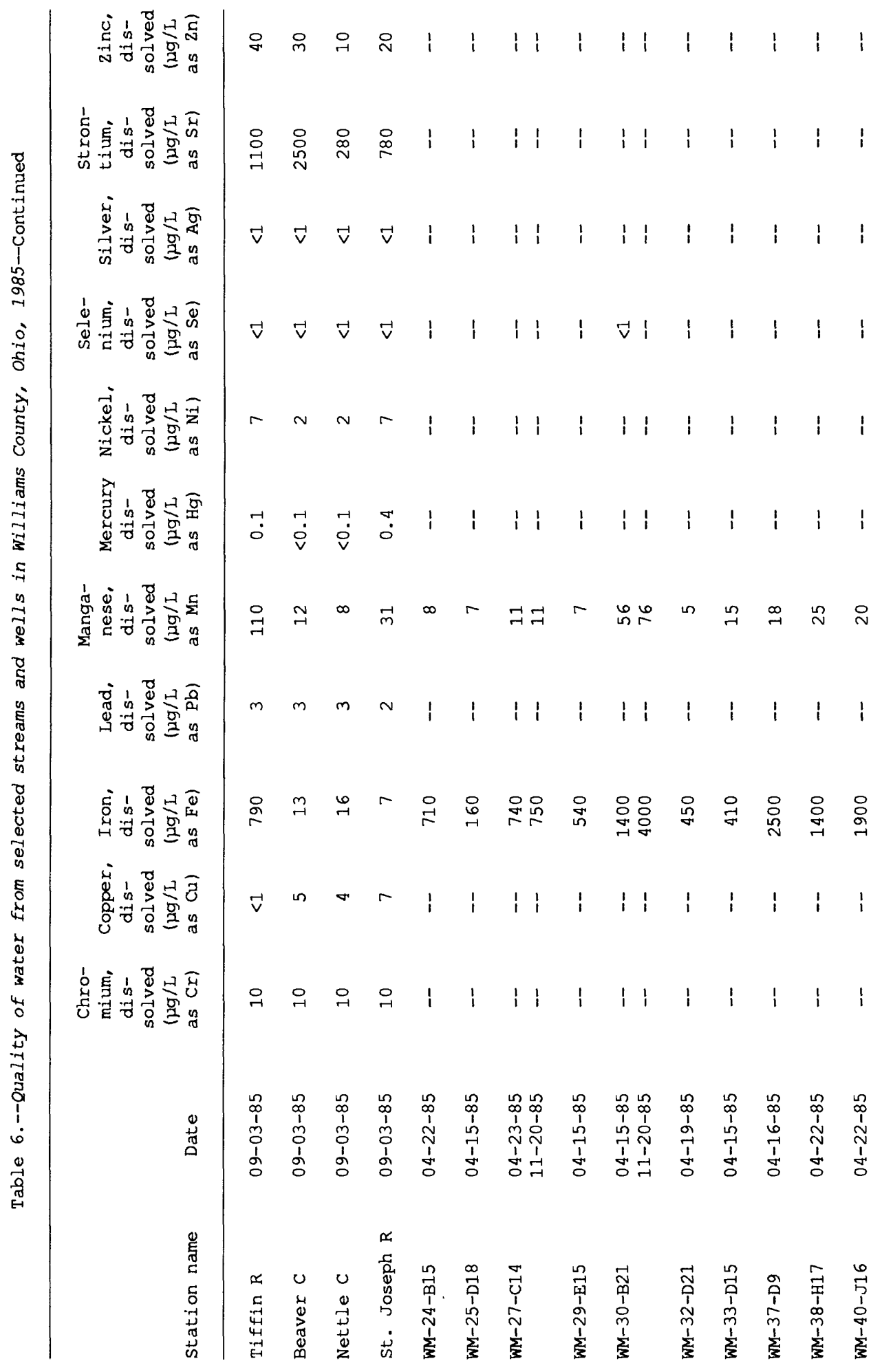




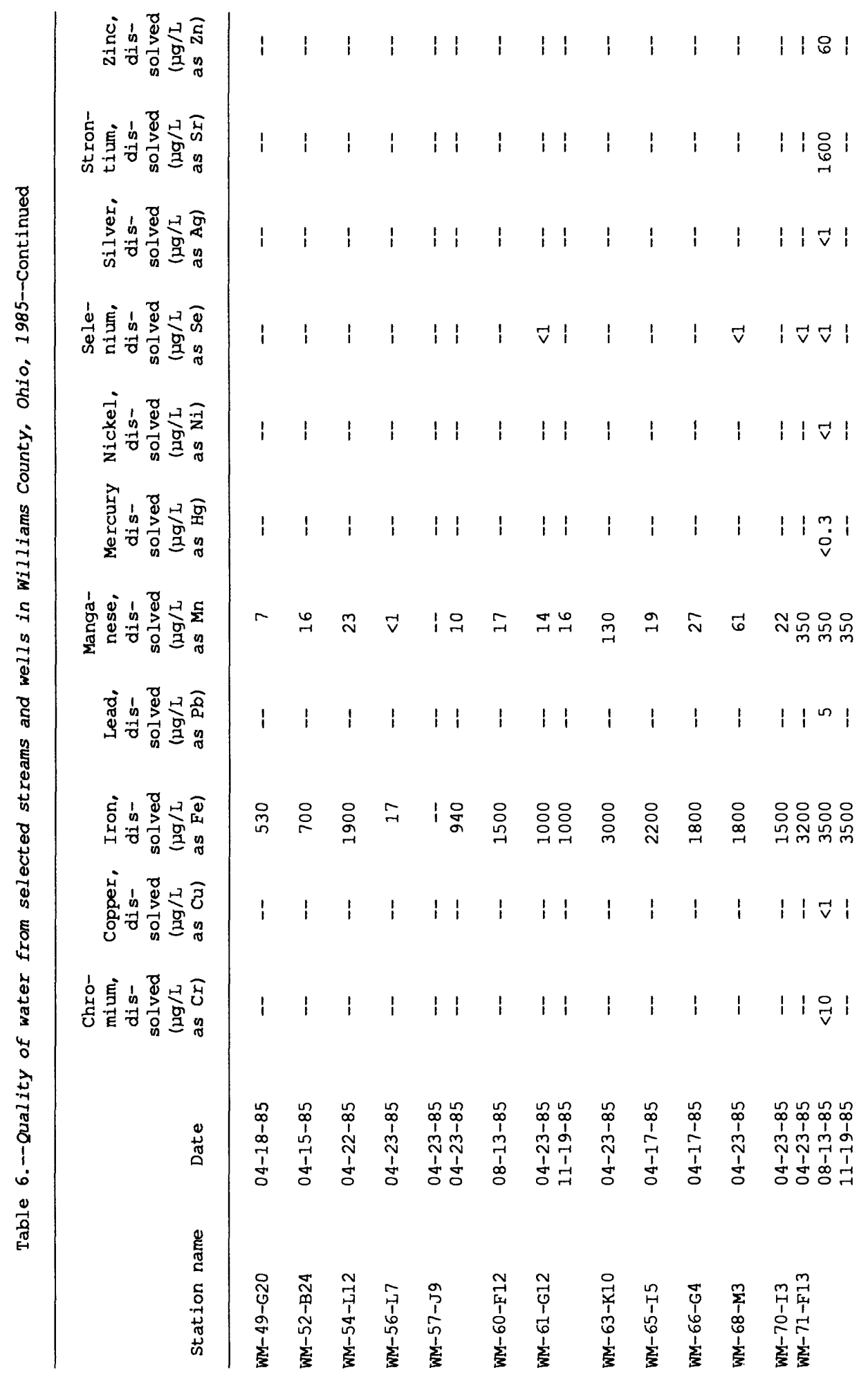




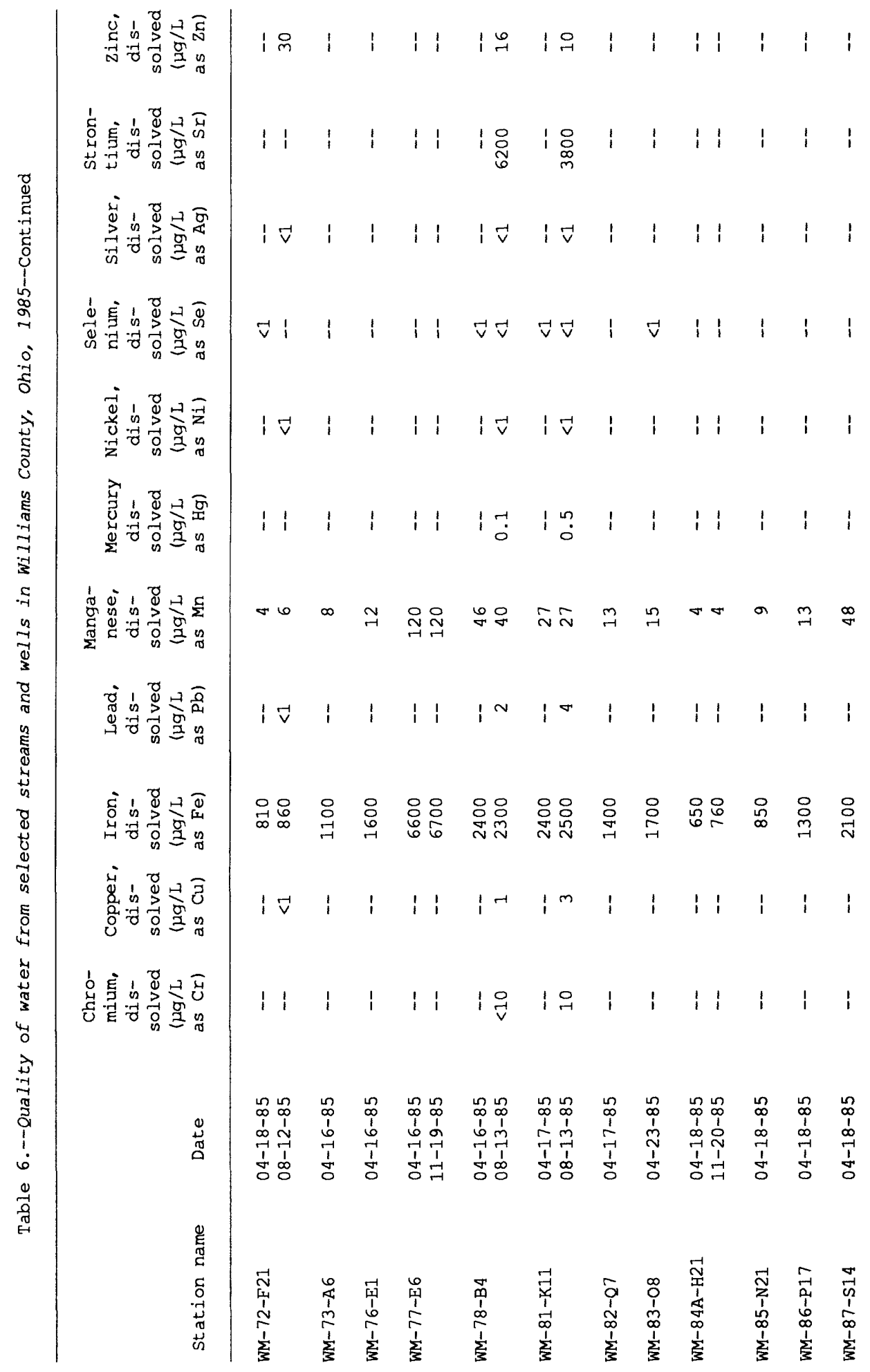




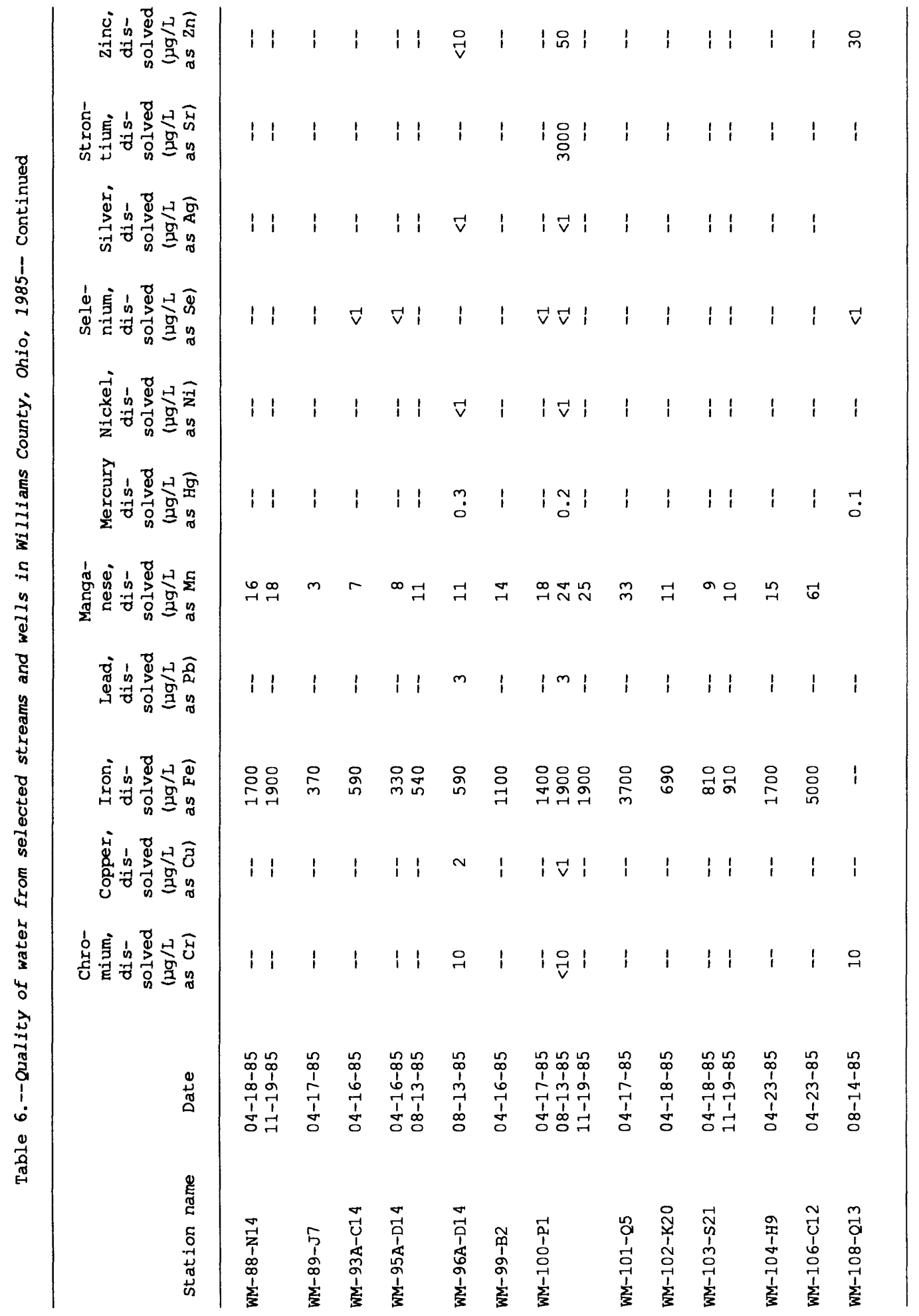


Table 8.--Characteristics or constituents that affect water quality (from

King, 1977)

\begin{tabular}{lcl} 
Characteristic & $\begin{array}{c}\text { Principal } \\
\text { cause or } \\
\text { source }\end{array}$ & Significance \\
\hline
\end{tabular}

Specific

conductance

Substances that form ions when dissolved in water.

$\mathrm{pH}$

Hardness

Alkalinity

Dissolved solids

Iron ( $\mathrm{Fe}$ ) and manganese $(\mathrm{Mn})$
Dissociation of water molecules and of acids and bases dissolved in water.

Calcium and magnesium dissolved in water.

Carbonate and bicarbonate ions produced by the solution of carbonate rocks, mainly limestone and dolomite, by water containing carbon dioxide.

Mineral substances dissolved in water.

Iron present in most soils and rocks; manganese less widely distributed.
Most substances in water dissociate into ions that can conduct an electrical current. Consequently, specific conductance is a valuable indicator of the amount of material dissolved in water. The greater the conductivity, the more mineralized the water.

The $\mathrm{pH}$ of water is a measure of its reactive characteristics. Low values of $\mathrm{pH}$, particularly below $\mathrm{pH} 4$, indicate a corrosive water that will tend to dissolve metals and other substances that it contacts. High values, particularly above $\mathrm{pH} 8.5$, represent an alkaline water that on heating will tend to form scale. The $\mathrm{pH}$ significantly affects the treatment and use of water.

Calcium and magnesium combine with soap to form an insoluble precipitate and thus hamper the formation of lather. Hardness also affects the suitablity of water for use in steam boilers and water heaters.

Controls the capacity of water to neutralize acids. Bicarbonates of calcium and magnesium decompose in steam boilers and water heaters to form scale and release corrosive carbon dioxide gas. In combination with calcium and magnesium, causes carbonate hardness.

Dissolved solids is a measure of the total amount of minerals dissolved in water and is therefore a very useful characteristic in the evaluation of water quality. Water containing less than 500 milligrams per liter is preferred for domestic use and for many industrial processes.

Both objectionable in food processing, dyeing, bleaching, ice manufacturing, brewing, and certain other industrial processes. Cause staining of plumbing fixtures and laundry. U.S. Environmental Protection Agency (USEPA) maximum contaminant levels (MCL's) (1977) recommend a maximum iron concentration of 300 micrograms per liter and a maximum manganese concentration of 50 micrograms per liter in drinking water supplies. 
Table 8.--Characteristics or constituents that affect water quality (from King, 1977)--Cont inued

\begin{tabular}{|c|c|c|}
\hline $\begin{array}{l}\text { Characteristic } \\
\text { or constituent }\end{array}$ & $\begin{array}{l}\text { Principal } \\
\text { cause or } \\
\text { source }\end{array}$ & Significance \\
\hline Sulfate $\left(\mathrm{SO}_{4}\right)$ & $\begin{array}{l}\text { Dissolved from } \\
\text { soils and rocks } \\
\text { containing gypsum, } \\
\text { pyrite, sulfides, } \\
\text { and other sulfur } \\
\text { compounds. Also } \\
\text { contained in some } \\
\text { industrial wastes. }\end{array}$ & $\begin{array}{l}\text { In high concentrations, imparts a bitter } \\
\text { taste to water and, at very high concen- } \\
\text { trations, has a laxative effect. When } \\
\text { combined with calcium, forms a hard } \\
\text { scale in steam boilers. EPA standards } \\
\text { (1977) recommend a maximum sulfate } \\
\text { concentration of } 250 \text { milligrams per } \\
\text { liter in drinking water supplies. }\end{array}$ \\
\hline Nitrate $\left(\mathrm{NO}_{3}\right)$ & $\begin{array}{l}\text { Present in ferti- } \\
\text { lizers, sewage, } \\
\text { soils, and in } \\
\text { decaying organic } \\
\text { matter. }\end{array}$ & $\begin{array}{l}\text { Because nitrate is a nutrient, it en- } \\
\text { ables growth of algae and other organ- } \\
\text { isms which may produce undesirable } \\
\text { tastes and odors. USEPA MCL's (1977) } \\
\text { recommend a maximum nitrate concentra- } \\
\text { tion of } 10 \text { milligrams per liter (as } \\
\text { nitrogen) in drinking water supplies, } \\
\text { as concentrations in excess of that } \\
\text { limit may cause methemoglobinemia in } \\
\text { infants. }\end{array}$ \\
\hline Fecal collform & $\begin{array}{l}\text { Originate in gas- } \\
\text { trointestinal } \\
\text { tract of humans }\end{array}$ & $\begin{array}{l}\text { Indicates contamination by human and } \\
\text { (or) animal wastes. Standard bacterio- } \\
\text { logical tests for these indicator } \\
\text { organisms are used to determine the } \\
\text { biological suitability of awater for } \\
\text { drining purposes. Generally, when the } \\
\text { ratio of concentration of fecal coliforr } \\
\text { bacteria to fecal streptococci bacteria } \\
\text { is greater than two, contamination by } \\
\text { human wastes is indicated; when the } \\
\text { ratio is less than one, contamination } \\
\text { by livestock or poultry wastes is } \\
\text { likely. Fecal streptococci bacteria } \\
\text { are themselves capable of causing } \\
\text { disease. }\end{array}$ \\
\hline $\begin{array}{l}\text { Calcium }(\mathrm{Ca}) \\
\text { and magnesium } \\
(\mathrm{Mg})\end{array}$ & $\begin{array}{l}\text { Soils and rocks } \\
\text { containing lime- } \\
\text { stone, dolomite, } \\
\text { and gypsum. }\end{array}$ & $\begin{array}{l}\text { These cations are the principal cause of } \\
\text { hardness and of boiler scale and depos- } \\
\text { its in hot-water heaters. Small amounts } \\
\text { of these constituents help to prevent } \\
\text { corrosion of metals and other substances } \\
\text { by otherwise aggressive waters. High } \\
\text { concentrations of magnesium may have a } \\
\text { laxative effect, particularly on new } \\
\text { users of the water. }\end{array}$ \\
\hline
\end{tabular}


Table 8.--Characteristics or constituents that affect water quality (from King, 1977)--Cont inued

\begin{tabular}{|c|c|c|}
\hline $\begin{array}{l}\text { Characteristic } \\
\text { or constituent }\end{array}$ & $\begin{array}{l}\text { Principal } \\
\text { cause or } \\
\text { source }\end{array}$ & Significance \\
\hline $\begin{array}{l}\text { Sodium (Na) and } \\
\text { potassium (K) }\end{array}$ & $\begin{array}{l}\text { Soils, rocks, some } \\
\text { industrial wastes, } \\
\text { and sewage. }\end{array}$ & $\begin{array}{l}\text { More than } 50 \text { milligrams per liter sodium } \\
\text { and potassium in the presence of sus- } \\
\text { pended matter causes foaming, which } \\
\text { accelerates scale formation and corro- } \\
\text { sion in boilers. In large concentra- } \\
\text { tions, sodium may adversely affect } \\
\text { persons with cardiac difficulties, } \\
\text { hypertension, and certain other medical } \\
\text { conditions. Depending on the concentra- } \\
\text { tions of calcium and magnesium also } \\
\text { present in the water, excessive sodium } \\
\text { may be detrimental to certain irrigated } \\
\text { crops. }\end{array}$ \\
\hline Chloride (Cl) & $\begin{array}{l}\text { Soils, rocks, some } \\
\text { industrial wastes, } \\
\text { and sewage. }\end{array}$ & $\begin{array}{l}\text { In large amounts, increases corrosive- } \\
\text { ness of water. Concentrations in ex- } \\
\text { cess of } 100 \text { milligrams per liter impart } \\
\text { a salty taste. USEPA MCL's ( } 1977) \\
\text { recommend a maximum chloride concentra- } \\
\text { tion of } 250 \text { milligrams per liter in } \\
\text { drinking water supplies. }\end{array}$ \\
\hline Fluoride (F) & $\begin{array}{l}\text { Small amounts dis- } \\
\text { solved from many } \\
\text { soils and rocks. } \\
\text { Added to many } \\
\text { waters by fluori- } \\
\text { dation of public } \\
\text { supplies. }\end{array}$ & $\begin{array}{l}\text { Low concentrations of fluoride have } \\
\text { beneficial effects on the structure and } \\
\text { resistance to decay of children's teeth. } \\
\text { Fluoride concentrations in excess of } \\
6.0 \text { milligrams per liter cause pro- } \\
\text { nounced mottling of tooth enamel and } \\
\text { disfiguration of teeth. }\end{array}$ \\
\hline Silica $\left(\mathrm{SiO}_{2}\right)$ & $\begin{array}{l}\text { Practically all } \\
\text { soils and rocks. }\end{array}$ & $\begin{array}{l}\text { In the presence of calcium and magne- } \\
\text { sium, silica forms a heat-conducting } \\
\text { hard, glassy scale in boilers. Silica } \\
\text { inhibits deterioration of zeolite-type } \\
\text { water softeners and corrosion of iron } \\
\text { pipes by soft water. }\end{array}$ \\
\hline
\end{tabular}


Table 9.--Some methods of dealing with problem water quality (from King, 1977)

$\begin{array}{ll}\begin{array}{l}\text { Problem or } \\ \text { constituent }\end{array} & \text { Treatment } \\ \text { processes }\end{array}$

Hardness, calcium (Ca) and magnesium (Mg)

Iron (Fe)

Manganese $(\mathrm{Mn})$ Same objectionable symptoms as iron, but generally forms brown or black stains. Removal is more difficult and commonly less complete than for iron.
1.--Iime-soda treatment--chemical reactions convert most $\mathrm{Ca}$ and $\mathrm{Mg}$ to insoluble calcium carbonate and magnesium hydroxide. The resulting precipitate can then be moved by sedimentation and filtration.

2.--Ion exchange--zeolite minerals or synthetic resin beads exchange sodium (Na) ions in their structure for $\mathrm{Ca}$ and $\mathrm{Mg}$ ions in the water. When their exchange capacity has been exhausted, they are regenerated by backflushing with a strong sodium chloride solution. The resin beads have a greater exchange capacity than the zeolite minerals.

1.--Oxidation and filtration--Aeration of water or treatment with chloride or potassium permanganate convert most $\mathrm{Fe}$ and $\mathrm{Mn}$ to insoluble precipitates which can then be removed by sedimentation and filtration. Aeration is commonly used when the water contains little organic matter; the chemical agents are utilized when large amounts of organic material are present, as in groundwater containing iron bacteria or in surface water. The water to be treated should be made alkaline before $\mathrm{Fe}$ or $\mathrm{Mn}$ removal is attempted.

2.--Oxidation and filtration through manganese green sand--The green sand liberates oxygen, which, in contact with the water, produces insoluble iron hydroxide and manganese oxide. When the available oxygen supply has been exhausted, the green sand is regenerated by backflushing a potassium permanganate solution through it.

3.--Ion exchange (see above). 
Table 9.--Some methods of dealing with problem water quality (from King, 1977)--Continued

\begin{tabular}{|c|c|c|}
\hline $\begin{array}{l}\text { Problem or } \\
\text { constituent }\end{array}$ & Symptoms & $\begin{array}{l}\text { Treatment } \\
\text { processes }\end{array}$ \\
\hline \multirow[t]{2}{*}{$\begin{array}{l}\text { Pathogenic } \\
\text { bacteria } \\
\text { including } \\
\text { fecal } \\
\text { strepto- } \\
\text { cocci }\end{array}$} & $\begin{array}{l}\text { Usually no symp- } \\
\text { toms displayed } \\
\text { by water although } \\
\text { high counts may } \\
\text { cause unusual } \\
\text { odor or color. }\end{array}$ & $\begin{array}{l}\text { 1.--Heating--Pasteurization by heating } \\
\text { water to } 161 \text { OF for } 15 \text { seconds or } \\
\text { boiling kills most bacteria and } \\
\text { viruses and does not impart objec- } \\
\text { tionable odor or taste to water. } \\
\text { 2.--Chemical--Chlorine may be intro- } \\
\text { duced into the water system at a } \\
\text { concentration sufficient to kill } \\
\text { bacteria after a contact time of } \\
\text { approximately } 30 \text { minutes. Other } \\
\text { reagents that may be used similarly } \\
\text { are iodine and potassium permanga- } \\
\text { nate. Chemical disinfection may } \\
\text { impart objectionable odors or } \\
\text { tastes to the water, but if desired, } \\
\text { they can be removed by subsequently } \\
\text { filtering the water through acti- } \\
\text { vated charcoal. }\end{array}$ \\
\hline & & $\begin{array}{l}\text { 3.--Ultraviolet light--Pass the water } \\
\text { to within } 1 \text { to } 5 \text { inches of a quartz- } \\
\text { mercury vapor lamp, which emits } \\
\text { ultraviolet light. Depending on } \\
\text { light intensity, the time of expo- } \\
\text { sure required for complete disinfec- } \\
\text { tion may be as little as one second. } \\
\text { This process does not impart objec- } \\
\text { tionable odor or taste to water. }\end{array}$ \\
\hline
\end{tabular}

